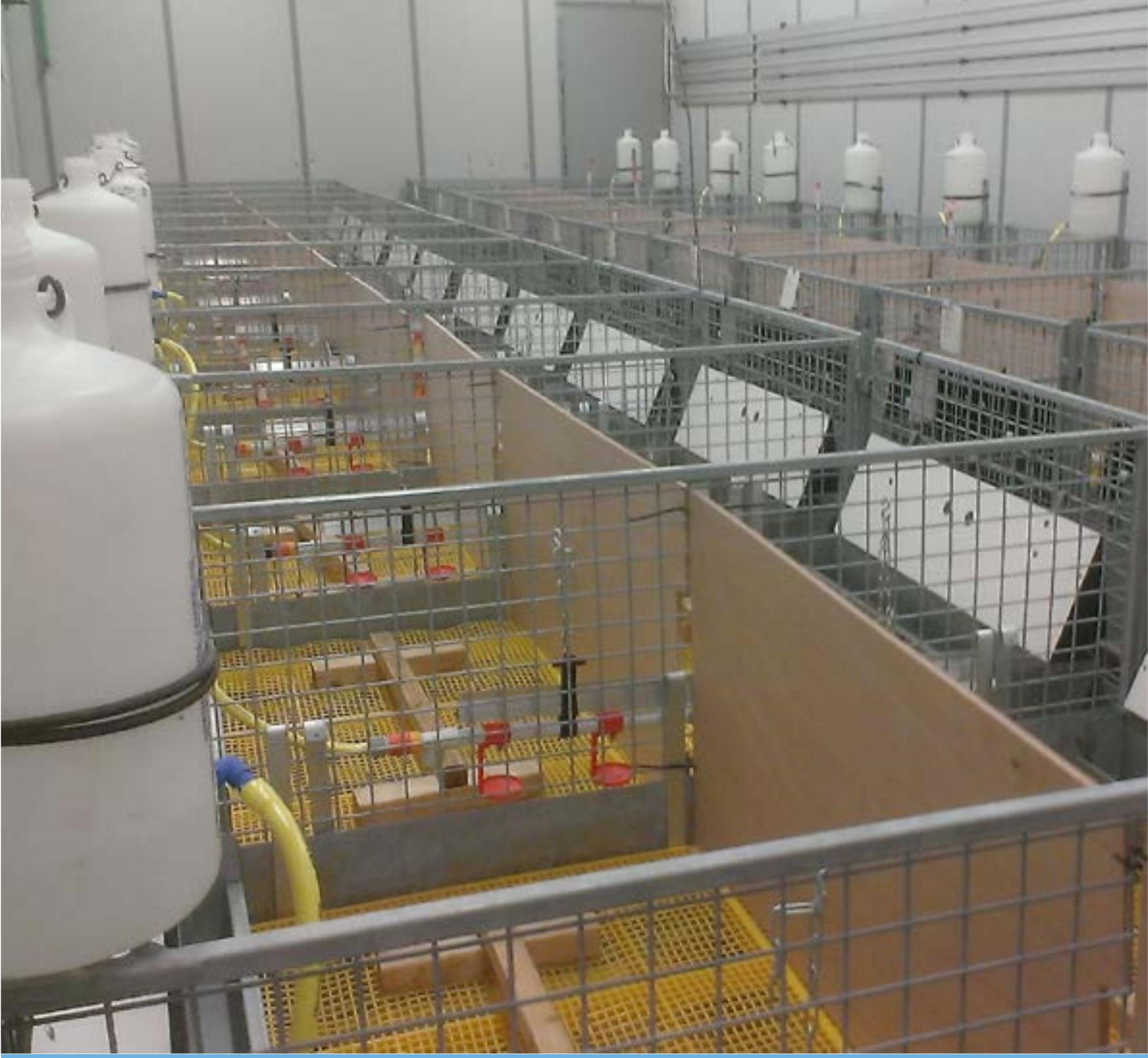

\title{
Phytate degradation in broilers
}




\section{Phytate degradation in broilers}

\section{Authors}

M.M. van Krimpen ${ }^{1}$, R.A. van Emous ${ }^{1}$, J.W. Spek ${ }^{1}$, and C. Kwakernaak ${ }^{2}$

${ }^{1}$ Wageningen UR Livestock Research

${ }^{2}$ Schothorst Feed Research

This research was conducted by Wageningen Livestock Research and Schothorst Feed Research, commissioned and funded by CVB and Feed4Foodure (project number: 4400745-01) and partly funded by the Ministry of Economic Affairs (Policy Support Research project number BO-31.03-005-001

Wageningen UR Livestock Research

Wageningen, October 2016 

Van Krimpen, M.M., R.A. van Emous, J.W. Spek and C. Kwakernaak 2016. Phytate degradation in broilers. Wageningen Livestock Research, Report 978.

The current study aims to assess the conditions that are relevant for an appropriate method of determination of precaecal $P$ digestibility in broilers by reviewing literature and performing several experiments. The focus of the literature review is on phytate degradation. It's extent depends on various factors, which are assessed in this review. Moreover, four experiments were conducted to determine the effects of phytate level of the basal diet, as well as the level and source of supplemented $\mathrm{P}$ on phytate degradation and precaecal $\mathrm{P}$ digestibility, as determined according to the WPSA protocol.

This report can be downloaded for free at http://dx. doi.org/10.18174/391336 or at www. wur.nl/livestock-research (under Wageningen Livestock Research publications).

\section{(c) 2016 Wageningen Livestock Research}

P.O. Box 338, 6700 AH Wageningen, The Netherlands, T +31 (0)317 483953 ,

E info.livestockresearch@wur.nl, www.wur.nl/livestock-research. Wageningen Livestock Research is part of Wageningen University \& Research.

All rights reserved. No part of this publication may be reproduced and/or made public, whether by print, photocopy, microfilm or any other means, without the prior permission of the publisher or author.

The ISO 9001 certification by DNV underscores our quality level. All our research commissions are in line with the Terms and Conditions of the Animal Sciences Group. These are filed with the District Court of Zwolle.

Wageningen Livestock Research Report 978 


\section{Table of contents}

$\begin{array}{ll}\text { Foreword } & 7\end{array}$

$\begin{array}{ll}\text { Summary } & 9\end{array}$

1

$\begin{array}{ll}\text { Introduction } & 10\end{array}$

$\begin{array}{ll}\text { Literature review } & 13\end{array}$

2.1 The role of phosphorus in poultry nutrition $\quad 13$

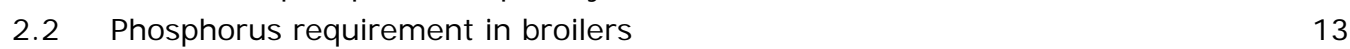

$\begin{array}{lll}2.3 & \text { Plant feedstuffs } & 14\end{array}$

$\begin{array}{lll}2.4 & \text { Animal feedstuffs } & 15\end{array}$

$\begin{array}{lll}2.5 & \text { Inorganic phosphates } & 16\end{array}$

$\begin{array}{lll}2.6 & \text { Phytate degradation } & 17\end{array}$

$\begin{array}{lll}2.7 & \text { Available phosphorus in broilers } & 19\end{array}$

2.8 Factors influencing phytate degradation and bioavailability of phosphorus in broilers $\quad 19$

2.8.1 Dietary calcium and Phosphorus level 19

2.8.2 Dietary vitamin $D_{3}$ level $\quad 20$

2.8.3 Age of the birds $\quad 21$

2.8.4 Sex of the bird $\quad 21$

$\begin{array}{ll}2.8 .5 \text { Soaking } & 21\end{array}$

2.8.6 Particle size $\quad 22$

2.9 Conclusions from literature $\quad 22$

$\begin{array}{llr}3 & \text { Experiments } & 23\end{array}$

$3.1 \quad$ Birds and management $\quad 23$

$\begin{array}{lll}3.2 & \text { Housing } & 23\end{array}$

3.3 Experimental diets 24

3.3.1 Experiment 1: effect of non-phytate P supplementation to a phytate low basal diet on P digestibility 24

3.3.2 Experiment 2: effect of non-phytate P supplementation to a phytate-rich basal diet on $\mathrm{P}$ digestibility

3.3.3 Experiment 3: effect of phytate P supplementation to a phytate-rich basal diet on $\mathrm{P}$ digestibility

3.3.4 Experiment 4: effect of dietary structure to a phytate-rich basal diet on $\mathrm{P}$ $\begin{array}{ll}\text { digestibility } & 27\end{array}$

$\begin{array}{lll}3.4 & \text { Observations } & 28\end{array}$

3.4.1 Performance 28

3.4.2 Dissection and sample collection $\quad 29$

3.4.3 Chemical analysis and calculations $\quad 29$

$\begin{array}{lll}3.5 & \text { Statistical analysis } & 30\end{array}$

4.1 Exp. 1: effect of nPP supplementation to a PP-low basal diet 31

4.2 Experiment 2: effect of nPP supplementation to a PP-rich basal diet 32

4.3 Experiment 3: effect of PP supplementation to a PP-rich basal diet 33 4.3.1 Results of the Wageningen Study 33

4.3.2 Results of the study of Schothorst Feed Research 35

4.4 Experiment 4: effect of added dietary structure to a PP-rich basal diet 36 
5.1 Precaecal P digestibility in phytate- low diets 38

5.2 Phytate degradation 38

$\begin{array}{lll}5.3 & \text { Precaecal versus faecal P digestibility } & 40\end{array}$

$\begin{array}{lll}5.4 & \text { Effect of dietary structure on phytate degradation } & 40\end{array}$

$\begin{array}{ll}\text { Conclusions } & 41\end{array}$

$\begin{array}{ll}\text { References } & 42\end{array}$

$\begin{array}{ll}\text { Appendix } 1 \text { Diagram of the experimental facility } & 49\end{array}$

$\begin{array}{ll}\text { Appendix } 2 \text { Photos of the experimental facility } & \mathbf{5 0}\end{array}$ 



\section{Foreword}

Phosphorus is an essential mineral and necessary to support the efficient growth and welfare of broilers. The stores of inorganic phosphorus in the world are limited, showing the importance of using organic phosphorus sources. Phytate represents the primary storage form of phosphorus in plant seeds. Phytate, however, is an anti-nutritional factor in poultry nutrition, interfering with phosphorus digestion. There are increasing evidences in the literature, however, that broiler possess endogenous phytase, which can be used to partly degrade phytate phosphorus, thereby making the organic phosphorus available for the birds. The present study focusses on several factors that affect the extend of phytate degradation in broilers, and finally provides some recommendations that should be taken into account in future phosphorus availability studies.

The present study have been conducted by Wageningen Livestock Research and Schothorst Feed Research at the request of CVB and the partners of Feed4Foodure, and is aimed to evaluate the phytate degradation in broilers. For the current study, scientists of the mentioned institutes worked together with representatives from the various private partners, including Agrifirm, ForFarmers, Nutreco, De Heus, Cargill, DSM, Groep van Zes, DIVA, and Centrico. The authors thank the industry partners of the project team for their worthwhile input. We would also like to thank the MSc students Kemi Adeboye and Xavier Yang Yongzhi for their enormous help in reviewing literature and assisting in the animal experiments.

Dr. Marinus van Krimpen, Study Director 


\section{Summary}

WPSA has published (2013) a standard protocol for determination of availability of phosphorus (P) in feedstuffs for broilers. It is based on precaecal P digestibility (pcdP). The current study aims to assess the conditions that are relevant for an appropriate method of determination of precaecal $P$ digestibility in broilers by reviewing literature and performing several experiments. The focus of the literature review is on phytate degradation. Although it was assumed that monogastrics are lacking endogenous phytase production, it's known from literature that broilers are able to degrade phytate. The extent of phytate degradation depends on various factors, which are assessed in this review. In the current study, four experiments were conducted to address four different research questions.

1. Effect of non-phytate $P$ supplementation to a phytate-low basal diet on phytate degradation and precaecal $P$ digestibility.

2. Effect of non-phytate $P$ supplementation to a phytate-rich basal diet on phytate degradation and precaecal $P$ digestibility.

3. Effect of phytate P supplementation to a phytate-rich basal diet on phytate degradation, precaecal and faecal $P$ digestibility.

4. Effect of dietary structure to a phytate-rich basal diet on phytate degradation and precaecal $P$ digestibility.

Experimental diets were fed as pellets to Ross 308 male broilers housed in 6 replicate cages, 10-12 birds per cage from 14 to 24 or 20 to $28 \mathrm{~d}$ of age. SBM was the only phytate source and MCP was used as non-phytate $\mathrm{P}$ source. Dietary $\mathrm{Ca} / \mathrm{P}$ ratio was kept at 1.35 and TiO2 was used as inert marker. Feed and water were freely available.

Based on findings of the present experiment, the following conclusions can be drawn:

- $\quad$ Literature shows that the dietary Ca, P, and Vitamin D content, the Ca: aP ratio and dietary structure affects phytate degradation in broilers.

- In phytate-low broiler diets, pcdP-\% was constant over a large aP-range.

- $\quad$ Phytate degradation showed a large variation among studies. Phytate degradation linearly decreased with increasing dietary non-phytate phosphorus content.

- $\quad$ The pcdP-\% of SBM determined according to the WPSA protocol does not differ from the faecal P digestibility according to the CVB protocol.

- $\quad$ Dietary structure did not affect phytate degradation and pdcP-\% of the diet, but increased precaecal Ca digestibility.

\section{Recommendations}

It can be recommended to use phytate-low diets for determining pcdP-\% of feed phosphates. Under this condition, the dietary total $\mathrm{P}$ content is not very critical, because the pcdP-\% was constant over a large dietary total $\mathrm{P}$ range ( 2.0 to $5.8 \mathrm{~g} / \mathrm{kg}$ according to a broken-stick model). It is recommended to use low nPP diets for testing the pcdP- $\%$ of phytate-rich ingredients. 


\section{$1 \quad$ Introduction}

Poultry meat consumption has experienced enormous growth in the last decade in many parts of the world due to its wide acceptability. It performs a vital role in the supply of quality protein to human population through the production of meat and eggs (FAO, 2003; Speedy, 2003). At a global level, broiler meat account for about $85 \%$ of total poultry meat (Huyghebaert et al., 2009), and its consumption is not hindered by any religious or cultural beliefs. Poultry are widely acknowledged in some parts of the world for important social and cultural roles in rural areas (FAO, 2010), contribute significantly to poverty alleviation and to reducing malnutrition in the most remote and underdeveloped areas of the world (Bloem et al., 2001). This growing demand for poultry meat has resulted in increasing attention on their production especially at nutrition level. A poultry feed must supply the necessary protein, carbohydrates, fats, minerals and vitamins in their proper proportion for maximum performance and good health. Poultry obtain energy and other required nutrients through the digestion of natural feedstuffs, but minerals, vitamins and some key essential amino acids are often offered as synthetic supplements.

It is generally recognized that the most efficient utilization of any ration depends upon the proper balance and quality of the nutrients therein. Nutritionists are making efforts to supply the right amount of nutrients to ensure efficient use of uptake by chickens. Minerals in poultry diet perform certain physiological functions (NRC, 1994); some are required relatively in large amount (macro) while the concentrations of others in the diets are needed only in trace amount (micro) (Ravindran, 2012). Minerals contribute to the structure of the body, as integral parts of the enzyme systems in the tissues, and participate in the functional activities of the body such as muscular activities (Mitchell, 1947). Among other minerals, Phosphorus (P) has been extensively investigated as an essential nutrient in poultry diets, and its major role in chick's growth performance and bone mineralisation (Underwood and Suttle, 1999) cannot be over-emphasized. The availability of P in feedstuffs of plant origin is of considerable importance since poultry diets consist primarily of feedstuffs of plant origin and a large, but variable portion of $P$ in these products is found in the phytate form (Van der Klis and Versteegh, 1999); a form which is usually considered to be unavailable to the birds. In most cases, monogastrics including poultry have inability to utilize phytate $\mathrm{P}$ and since bird requirements has to be met for this mineral; hence their diets are supplemented with inorganic feed phosphates (e.g. MCP or DCP) or phytases (Viljoen, 2001; Powell et al., 2011) to ensure optimal growth and performance. The act of adding inorganic phosphate to poultry ration can increase the cost of production (Selle and Ravindran, 2007), besides an adequate supply of P still remains an important issue being expensive in poultry diets (Singh, 2008), and taking into account its consequences in terms of negative environmental impacts as undigested phytate $\mathrm{P}$ is consequently excreted via the faeces.

Phytate is an anti-nutritional factor in poultry nutrition interfering with $\mathrm{P}$ digestion. There are some evidences in the literature, however, that broiler possess endogenous phytase which can be used to degrade part of phytate $P$ (Marounek et al., 2010) when fed P deficient diets. In an attempt to avert the deficiency of $P$ in broiler diets including reduced performance and excessive mortality (Waldroup, 1999), nutritionist often adopt a safety margin when formulating the diets to guarantee performance. This practice is usually done as a result of excessive phytate bound $P$ which is not available to the bird; nevertheless, there is tendency to oversupply $\mathrm{P}$ due to uncertainty with plant $\mathrm{P}$ sources. The problem resulting from this practice can be enormous especially in the areas of concentrated animal production because excess undigested phytate $\mathrm{P}$ poses danger to the environment and water bodies causing eutrophication. Therefore, comprehensive studies related to phytate degradation in poultry can contribute improving $P$ utilization as well as the efficient and sustainable use of $P$ sources now and in the future; as this will not only decrease the cost of production but also minimises the environmental impact.

$\mathrm{P}$ is a non-renewable resource and $90 \%$ of the demand for $\mathrm{P}$ is for food production (Gunther, 2005). An analysis by Richards and Dawson (2008), reported that Phosphorus supply in EU 27 is highly dependent on imports. Besides, global raw phosphate resources, which are needed for feed phosphate production, are limited. In addition, Phosphorus reserves are declining and rock phosphate could be exhausted in 50-100 years (Cordell et al., 2009). Conserving $P$ resources has been recognized as a 
major confrontation for sustainable food production (Gross, 2010; Neset and Cordell, 2011). In response to the need of $P$ for animals and environmental load, effort has been made by some countries in order to optimize the use of dietary P (Rodehutscord and Dieckmann, 2005). Thus, responsible handling of $P$ sources is an important issue in poultry production system, and it might be interesting to explore the nature of phytate degradation of certain feed ingredients in poultry to improve $\mathrm{P}$ availability and utilization.

The amount of phytate in many feed ingredients varies significantly, which may have impact on the $P$ level of each ingredient. The ability of a bird to digest and absorb $P$ from the diets lies in their capacity to degrade phytate $\mathrm{P}$ which make this to represent an important issue in broiler nutrition, due to bird's inability to produce sufficient amount of endogenous phytase to hydrolyse phytate into inorganic $P$ (iP) and inositol. In an attempt to supply adequate amount of $\mathrm{P}$ required, various systems have been developed based on available phosphorus (aP) digestibility in broilers. For example, the current Dutch system of retainable phosphorus $(\mathrm{rP})$ in broilers is based on experiments that determined the apparent faecal $P$ digestibility at low dietary $P$ levels, which sometimes may be inappropriate due to enteric fermentation and endogenous loss in the hind gut. Thus, preference has been given to estimation of aP in the ileum. For example, Van Krimpen et al. (2013), reported faecal P digestibility coefficients to be $10.5 \%$ lower compared to ileal P digestibility ( 46.8 vs $36.3 \%$ ). It was concluded that ileal digestibility values provide a better insight in the $\mathrm{P}$ metabolism compared to faecal digestibility.

Ileal digestibility, also called precaecal digestibility (pcd), is an established criterion for measuring nutrients availability in poultry. It refers to that proportion of dietary total $P$ that is not recovered in the content of the terminal ileum, usually determined by including an indigestible marker in the feed (WPSA, 2013). It is preferred because the values are unaffected by post-ileal microbial activity. Studies on PC measurement of P digestibility have been documented in young turkeys at the lower half of the ileum with the aid of yttrium-91 as a reference substance (Hurwitz et al., 1978).

Dieckmann (2004) and Shastak et al. (2012) assessed the PC digestibility of P in various inorganic feed phosphates in broilers.

The current study aims to assess the conditions that are relevant for an appropriate method of determination of precaecal $\mathrm{P}$ digestibility in broilers by reviewing literature and performing several experiments.

Literature review (Chapter 2)

The focus of the literature review is on phytate degradation. Although it was assumed that monogastrics are lacking endogenous phytase production, it's known from literature that broilers are able to degrade phytate. The extent of phytate degradation depends on various factors, which are assessed in this review. It's already reported (Van der Klis and Blok, 1997) that phytate degradation depends among others on the dietary aP and Ca content and the phytate content.

\section{Experiments (Chapter 3)}

In the current study, four experiments were conducted to address four different research questions.

1. Effect of non-phytate $P$ supplementation to a phytate-low basal diet on precaecal $P$ digestibility It is assumed that $P$ digestibility in phytate-low diets will be constant and maximal as long as the dietary aP content is below the aP requirement of the broilers. $\mathrm{P}$ digestibility would expect to decrease if the dietary aP content is above the $\mathrm{P}$ requirement. The response of broilers in terms of $\mathrm{P}$ digestibility to a large range of dietary aP in phytate-low diets, however, is unknown. It is important to know at what dietary $\mathrm{P}$ content the line starts to deviate from linearity to assure that digestibility studies are conducted in a linear range. Therefore, experiment 1 was performed to determine the response in precaecal P digestibility on incremental dietary aP contents in phytate-low diets in the range from 1.0 to $6.0 \mathrm{~g} \mathrm{rP} / \mathrm{kg}$ of diet, thereby covering the range of $32 \%$ to $194 \%$ of the recommended required $\mathrm{rP}$ (CVB, 2012).

2. Effect of non-phytate $P$ supplementation to a phytate-rich basal diet on precaecal P digestibility Based on earlier experiences, it is expected that phytate degradation in broilers of $25 \mathrm{~d}$ of age will start below a dietary aP content of about $3.5 \mathrm{~g} / \mathrm{kg}$. The level of phytate degradation was inversely proportional with the dietary rP content (Van der Klis and Blok, 1997). Therefore, the determination of 
precaecal P digestibility of a nPP source (MCP), supplemented to a phytate-rich basal diet, might be affected by varying levels of phytate degradation. Therefore, in experiment 2 , the effect of nonphytate $\mathrm{P}(\mathrm{MCP})$ supplementation $(+1.5$ and $3.0 \mathrm{~g} / \mathrm{kg} \mathrm{rP})$ to a phytate-rich basal diet $(1.5 \mathrm{~g} / \mathrm{kg} \mathrm{rP})$ on precaecal $P$ digestibility was determined.

3. Effect of phytate $P$ supplementation to a phytate-rich basal diet on precaecal $P$ digestibility An additional question was to what extend the precaecal $P$ digestibility of varying inclusion levels of a phytate-rich test ingredient, supplemented to a phytate-rich basal diet, would be affected by the level of phytate degradation. The relation between phytate content and phytate degradation was unknown. We expected an increased $\mathrm{P}$ digestibility compared to the calculated value if phytate is available in a low $\mathrm{P}$ basal diet as compared to a phytate low and $\mathrm{P}$ low basal diet. Therefore, in experiment 3, 11\% and $22 \%$ of a phytate-rich test ingredient (SBM), respectively, were supplemented to a phytate-rich basal diet, containing $40 \%$ of SBM. Experiment 3 belonged to a ringtest, in which the recent developed protocol for determination of the precaecal digestible phosphorus content (WPSA, 2013) was tested by many research institutes all over the world.

Because the current Dutch rP system is actually based on faecal P digestibility values, faecal digestibility of these diets will be determined as well. Schothorst Feed Research, which also joined this ringtest, determined within the framework of the current study in their ringtest both the precaecal $P$ digestibility and the faecal $P$ retention of the test diets (Chapter 5 ).

4. Effect of dietary structure to a phytate-rich basal diet on precaecal P digestibility Dietary structure increased mean retention time in foregut of laying hens (Van Krimpen et al., 2011), although these findings were not confirmed in broilers (Hetland and Svihus, 2001; Svihus et al., 2002). Nevertheless, it is hypothesized that dietary structure would improve mixing of digesta with enzymes and acids, which are secreted by the proventriculus. Therefore, in experiment 4 the effect of adding a structural component (coarse oat hulls) to a phytate-rich basal diet on precaecal $\mathrm{P}$ digestibility was determined. 


\section{$2 \quad$ Literature review}

\section{$2.1 \quad$ The role of phosphorus in poultry nutrition}

Phosphorus is one of the macro-minerals needed in poultry diets for normal growth and development (Zhang et al., 2003), and it is the second most abundant mineral in the body after calcium (Ca). P is well known for its involvement in many metabolic and structural processes (Soares, 1995). It is needed for attaining optimum genetic potential in growth, feed efficiency as well as skeletal development. Because of the key role of $\mathrm{P}$ in growth, bone development and mineralization, the requirements of the animals for $\mathrm{P}$ are the highest during the time the animal is growing (Applegate and Angel, 2004). In addition to its function in bone, $\mathrm{P}$ also plays a key role in carbohydrate and fat metabolism, and in the regulation of the acid-base balance of the body (J acobs et al., 2003). It can be found in phosphoproteins, nucleic acids, and phospholipids. It is also part of ADP and ATP, making it essential in energy metabolism (McDonald et al., 2002). P forms parts of the deoxy and ribonucleaic acids which are necessary for cell growth and differentiation. It constitutes part of the phospholipids required to preserve the cell membrane fluidity and integrity (Underwood and Suttle, 1999). Since $P$ serves as one of the most abundant minerals found in bone tissue, constituting approx. $170 \mathrm{~g} / \mathrm{kg}$ of the bone ash (Waldenstedt, 2006), it is thus important to satisfy the requirement in order to assure an adequate skeletal development of the rapidly growing broiler (Yan et al., 2001).

Adequate supplementation of $\mathrm{P}$ in poultry diets is of considerable importance to prevent nutritional deficiencies or abnormalities. Mineral deficiencies or imbalances occur when animal requirements are not met because of low mineral content in the feedstuff; low biological availability of the mineral or substances interferes with the absorption of the mineral by the animal. Poultry derive their phosphorus needs from plant products and feed supplements. Excess $P$ in the diet reduces the availability of other divalent cations which make poultry manure to be rich in pollutant (N\&P) (Toor et al., 2009). P deficiency can result in deleterious effects such as decreased performance, impaired metabolic processes and poor nutrient utilization (Scott et al., 1982). In most cases, inadequate supply of $\mathrm{P}$ can be manifested through loss of appetite, subnormal growth, locomotion problems, ricket or osteomalacia and even death (Larbier and Leclercq, 1994; McDonald et al., 2002). An experiment was conducted by Drivers et al. (2006) where broilers were fed diets deficient in both Ca and $\mathrm{P}$ containing $0.60 \% \mathrm{Ca}$ and $0.47 \%$ total $\mathrm{P}$ diets during the starter phase (0-18 days) and $0.30 \%$ $\mathrm{Ca}$ and $0.37 \%$ total $\mathrm{P}$ during the grower phase (19-35 days) without supplementation. The diet was fed throughout the experiment, and the results showed that broilers demonstrated poor bone mineralization, considerable leg problems, and a high incidence of broken bones after processing, compared with broilers fed adequate diets during the starter period $(0.90 \% \mathrm{Ca}$ and $0.68 \% \mathrm{tP})$ and the grower period $(0.80 \% \mathrm{Ca}$ and $0.67 \% \mathrm{tP})$. This experiment suggests that the deficiency of these minerals is critical in broiler nutrition. Although, it is possible to decrease the $P$ level in the finishing period if the Ca content is appropriate (Rousseau et al., 2012), however optimal threshold has to be determined.

\subsection{Phosphorus requirement in broilers}

In poultry nutrition, mineral requirement can vary within flock according to species, age, sex and level of performance. Phosphorus requirements in poultry are affected by numerous factors, including the dietary level of calcium (Rama Rao et al., 1999), the requirement vary with growth phase and may be different depending on broiler strain ( $\mathrm{J}$ imenez-Moreno et al., 2013). The utilization of phytate by poultry ranges from 0 to $50 \%$ depending on age and metabolic adaptation in critical circumstances (Manangi and Coon, 2008). Broilers have to be received enough dietary $P$ to meet the requirements for synthetic processes for growth (Larbier and Leclercq, 1994). Bio-availability is a major concern as nutrients can interact with one another or with other dietary components at the site of absorption, resulting in a change of bioavailability level. Phosphorus digestibility by poultry has been shown to be affected by the amount of Ca, P and their ratio in the diet (Gunther and al-Masri, 1988; al-Masri, 1995; Driver et al., 2005; Selle et al., 2009) due to the antagonizing relationship between $C a$ and $P$ in the intestine of broiler chickens. The $P$ requirement for broilers has emerged as an important issue 
over the years due to excretion of certain unutilized mineral compounds such as phytate P (PP) from large scale poultry farming, and is continuously revised by new research because the genetic selection for higher growth rate as reflected in the present fast growing commercial broilers might requested for a different $P$ requirement.

Heloisa et al. (2012) suggested that low levels of aP are required in broiler's diet because the requirement of this mineral reduced as bird aged; the aP requirement reported for male broilers from $1-10,11-21,22-33$, and 34-46 days of age are 4.82, 4.10, 3.95 and $3.19 \mathrm{~g} / \mathrm{kg}$, respectively. The level of aP required by broilers at the starter phase can be high, but this amount may be reduced during the growth and finishing phase (Heloisa et al., 2012). The nPP requirements per age according to NRC are provided in Table 1.

Table 1 Non-phytate phosphorus (nPP) requirements at different phase for broilers (NRC, 1994).

\begin{tabular}{ll} 
Age $(w k)$ & $n P P$ requirements $(\%)$ \\
$0-3$ & 0.45 \\
\hline $3-6$ & 0.35 \\
\hline $6-8$ & 0.30 \\
\hline
\end{tabular}

The use of Ca: aP at 2: 1 can lead to a reduction of dietary levels of $\mathrm{P}$ without compromising the performance and mortality of birds. Several factors have been identified to influence the $P$ requirement, among which the composition of the diet (Fritz et al., 1969; Pointillart et al., 1987), management (Mathur et al., 1982; Daghir and Farran, 1983), and climatic environment (Sell et al., 1987) are important. Dietary $P$ content either high or low may adversely affect bird's performance. The excess dietary $P$ is not only detrimental to the bird but also reduces the availability of other divalent cations and phytin phosphorus by reducing phytate hydrolysis (Ballam et al., 1985), subsequently leading to environmental pollution.

\subsection{Plant feedstuffs}

Poultry feed arise from plants (usually corn and soybean) and phosphorus in plant feedstuffs exist in two forms: organic and inorganic. In the organic form, most phosphorus is bound in phytic acid (Figure 1) or phytate which cannot be absorbed as such from the intestine by poultry. Therefore, broilers are dependent on the presence of phytate hydrolysing enzymes (e.g. phytase) found either in the ingredients, supplemented from microbial origin products or in intestinal secretion to utilize phytate phosphorus. According to Ravindran et al. (1995), phytate-phosphorus within a given feedstuff is variable but typically averages $72 \%$ of the total seed phosphorus in corn and $60 \%$ in soybean meal. Phytic acid (myoinositol, 1,2,3,4,5,6 hexakis-dihydrogen phosphate) and phytate (salt of phytic acid) are commonly found in plant seed grains because it constitutes the major portion of total phosphorus in several seeds and grains. Efforts are continually made to have more knowledge of phytate degradation in poultry because of its binding ability to limits the availability of other dietary nutrients. Furthermore, phytic acid is negatively charged at acidic, neutral and basic pH conditions (Maenz, 2001). Thus, it has the ability to bind both positively charged molecules in the diets and in endogenous gastrointestinal tract secretions, including digestive enzymes and mucins at all $\mathrm{pH}$ conditions found in the GIT, thereby reducing nutrient digestibility. The phytic acid content varies greatly among plants depending on the type of seeds, environmental condition, climate, and soil quality; about 60-90\% of total phosphorus in plant feedstuffs is bound as phytates phosphorus (Wu et al., 2009). Also, its concentration in different ingredients which are usually used in poultry feeds varies depending on several factors including type and variety of ingredients, and year of harvesting. Steiner et al. (2007) reported a significant influence of harvest year on phytate $P$ contents in wheat and various phytase activities between different cultivars of barley. Mean concentrations of phytate $P$ $(\mathrm{g} / \mathrm{kg})$ of common feed ingredients are presented in Table 2. 
Table 2 Mean concentration of phytate P $(\mathrm{g} / \mathrm{kg})$ of common feed ingredients.

\begin{tabular}{ll} 
Ingredient & Phytate P (g/ kg) \\
Wheat & $2.2^{1}, 2.9^{2}$ \\
\hline Barley & $2.2^{2}, 2.6^{2}$ \\
\hline Triticale & $2.5^{1}, 2.8^{2}$ \\
\hline Rye & $2.2^{1}, 2.4^{2}$ \\
\hline Corn & $2.1^{3}, 2.3^{4}$ \\
\hline Sorghum & $2.4^{3}$ \\
\hline Wheat bran & $7.9^{2}$ \\
\hline Rye bran & $4.9^{2}$ \\
\hline Soybean meal & $4.5^{3}, 3.8^{4}$ \\
\hline Canola meal & $6.7^{3}$ \\
\hline${ }^{1}$ Eeckhout and De Paepe (1994) & \\
${ }^{2}$ Steiner et al. (2007) & \\
${ }^{3}$ Selle et al. (2003) & \\
${ }^{4}$ Devegowda (2005) &
\end{tabular}<smiles>O=P(O)(O)O[C@H]1[C@H](OP(=O)(O)O)[C@@H](OP(=O)(O)O)[C@H](OP(=O)(O)O)[C@@H](OP(=O)(O)O)[C@H]1OP(=O)(O)O</smiles>

Figure 1 Structure of Phytic acid (source: wikipedia.org/wiki/Phytic_acid)

\subsection{Animal feedstuffs}

Animal protein supplements have long been used by the poultry industry both for their high quality protein as well as their phosphorus content, some commonly used animal protein sources are fishmeal, bone and meat meal and poultry by-product meal. Phosphorus content of animal protein meal were highly available compared with monosodium phosphate (Dozier et al., 2012) as reported by a study which showed that diets containing fishmeal supported better growth than diets based entirely on vegetable protein sources (Hossain et al., 2011). It is evident that there may be little or no phytate in a diet formulated with large proportions of animal products as a protein or $\mathrm{P}$ source or with diets that already contain a high concentration of intrinsic phytase (Eeckhout and De Paepe, 1992;

Dungelhoef et al., 1994). Total, phytate $P$ and available $P$ content of different plant and animal protein sources are presented by Devegowda (2005) in Table 3. In this publication, available P has been calculated as total $\mathrm{P}$ minus phytate $\mathrm{P}$. 
Table 3 Total, phytate P and available P content of different feed ingredients (Devegowda, 2005).

\begin{tabular}{llll}
\hline Ingredient & Total P $(\%)$ & Phytate P (\%) & 0.27 \\
Soybean meal & 0.65 & 0.38 & 0.19 \\
\hline Groundnut extraction & 0.68 & 0.49 & 0.30 \\
\hline Sunflower extraction & 0.92 & 0.62 & 2.00 \\
\hline Fish meal & 2.00 & - & 4.00 \\
\hline Meat meal & 4.00 & - & 16.18 \\
\hline Dicalcium phosphate & 16.18 & - & 0.13 \\
\hline Maize & 0.36 & 0.23 & 0.04 \\
\hline Rice broken & 0.32 & 0.28 & 0.24 \\
\hline Bajra & 0.65 & 0.41 & 0.15 \\
\hline Rice polish & 1.25 & 1.10 & 0.19 \\
\hline De oiled rice bran & 1.35 & 1.16 & 0.19 \\
\hline
\end{tabular}

Variation in $\mathrm{P}$ availability from organic as well as inorganic sources has been associated with the type or form of $\mathrm{P}$ source, $\mathrm{P}$ content, differences in result of laboratory analyses, inadequate description of product quality, seasonal changes and digestibility of $P$ the source (Gillis, et al., 1954; Peeler, 1982; Ketels and DeGroote, 1988; Jones, 1989). In addition, texture or particle size is another factor that can influence phosphorus availability and utilization of a dietary supplement (Griffith, 1969).

Generally, the more soluble an P source, the greater its biological value (McGillivray, 1978), thus particle size of animal protein source such as bone meal may play a role in its $\mathrm{P}$ availability and utilization. However, there can be variation in the amount of available P provided by various organic sources. An experiment carried out by Orban and Roland (1992), on the use of different bone meal sources on boilers showed no influence on tibial and femoral weight, strength and ash content broilers. The result further reported less $\mathrm{P}$ utilization from catfish and swine bone meals for growth of the metatarsal bones than P from chicken, cattle or mixed bone meal. It has been shown that other plant feed ingredients such as wheat; barley and rye have considerable endogenous phytase which might possibly influence the phytate hydrolysis and consequently improving $P$ availability. On the other hands, others have little or no phytase activity (corn, oats, sorghum and oilseeds) (Eeckhout and de Paepe, 1994). Plant phytases are active at a temperature between 45 to $60^{\circ} \mathrm{C}\left(113\right.$ to $\left.140^{\circ} \mathrm{F}\right)$ (Wodzinski and Ullah, 1996), and temperature stability of plant phytases can be a primary drawback particularly when the diets are pelleted since phytases are enzymes which may be partially or totally inactivated by high steam-pelleting temperatures (Ravindran et al., 1995). Despite higher phosphorus digestibility in animal protein source, these sources stand greater risk of possible contamination; since the prohibition of meat and bone meal in Europe, other animal protein sources such as egg white powder and casein are in use. A study by Cowieson et al. (2006) showed that casein was found to be highly digestible in the parameters measured in the absence of IP6, with true coefficients of DM, N, and amino acid digestibility of between 85 and $100 \%$.

\subsection{Inorganic phosphates}

Phosphorus supplementation of poultry feeds is regularly carried out by the addition of inorganic phosphates such as mono-calcium phosphates, mono di-calcium phosphates and de-fluorinated phosphate etc. Phosphorus sources can substantially influence $P$ availability (Sarker et al., 2009). Among the different inorganic $P$ sources used in poultry feed, the bioavailability of $P$ differs, some studies have reported that the bioavailability of $\mathrm{P}$ from mono-calcium phosphate monohydrate (MCP) was more available than that from any of the other sources of $\mathrm{P}$ including di-calcium phosphate dehydrate (Potter et al., 1995). Similarly, Hemme et al. (2005) showed that MCP and DCP had a higher P utilization (46.0 and $45.7 \%$ ) compared to defluorinated phosphate (DFP; 35.5\%) when broilers were fed with different inorganic $P$ sources. Table 4 provides the $P$ availability (digestibility) of several inorganic phosphate sources measured in broilers (Van der Klis and Versteegh, 1996). 
Table 4 Phosphorus availability (digestibility) of inorganic phosphate sources measured with broilers (source: Van der Klis and Versteegh, 1996).

\begin{tabular}{lll} 
P source & Total P (\%) & Digestible P (\% of total) \\
MCP (Mono-calcium phosphate) & 22.6 & 84 \\
\hline MDCP (Mono-dicalcium phosphate) & 21.3 & 79 \\
\hline DCP (hydrous) (Di-calcium phosphate) & 18.1 & 77 \\
\hline DCP (anhydrous) (Di-calcium phosphate) & 19.7 & 55
\end{tabular}

\subsection{Phytate degradation}

Phytate degradation may occur in the gastrointestinal tract prior to the site of intestinal absorption. In the digestive tract of poultry, phytate has to be hydrolysed to inorganic phosphate for utilization to take place. Therefore, the ability of broilers to utilize phytate $\mathrm{P}$ will depend upon their ability to liberate phosphate ions from the phytate molecule by hydrolysis. Phytase supplementation in poultry diets is a common practice due to inadequate intrinsic phytase activity in the digestive tract. To some extent, however, broilers can utilize part of phytate $\mathrm{P}$ without phytase supplementation (Edwards, 1993; Leske and Coon, 2002). In a study conducted by lyayi et al. (2013), the true P digestibility of black-eyed pea and peanut flour with or without phytase supplementation in broiler chickens was determined. The results showed a true P digestibility of 29 and $67 \%$ respectively, for both black-eyed pea and peanut flour without phytase supplementation. Studies have confirmed that phytic acid reduces the bioavailability of phosphorus, calcium, magnesium, zinc and other minerals. The availability of these minerals may increase through degradation of and/or hydrolytic splitting of the ester bond of phytic acid through various processing effects by phytase either from animal, plant or microbial sources (Singh, 2008).

Phytate- $P$ digestion is a complex process and can differ significantly with the diet composition and the physical conditions in the digesta. The impact of phytate activities in animal is of greater concern through its ability to inhibit the activity of digestive enzymes in the gastro intestinal tract, and phytate digestibility is largely depending upon the efficiency of hydrolysis of phytate prior to feeding and during digestive passage (Maenz, 2001). Liebert et al. (1993), demonstrated detectable exogenous phytase activity of $25-50 \%$ in the crop and proventriculus of broilers, while no activity was detected in the small intestine in 3-5 wk old chicks. They concluded that the crop and proventriculus were the major functional sites for exogenous phytase in poultry. Marounek et al. (2010) estimated in an in vitro study the intestinal and total tract phytate digestibility and phytase activity in the digestive tracts of laying hens and broiler breeder fed a wheat-maize-soybean diet. Contrary to Liebert et al. (1993), they found phytase activities throughout the whole digestive tract with specific phytase activities (related to $1 \mathrm{~g}$ of digesta or feed) in the crop, stomach, small intestinal contents, mucosa and caecal contents of $10.2,9.2,14.6,11.5$ and $135 \mu \mathrm{mol} . \mathrm{h}-1 \mathrm{~g}-1$, respectively. It was demonstrated that the highest phytase activities was found in the caeca presumably of microbial origin suggesting that phytate degradation might occur in the hindgut. Phytate P was partially digested in hens fed diets without phytase supplementation.

In the gastro intestinal tract, the activities of phytase could be obtained from the intestinal mucosa and gut microflora (Griener et al., 1993). However, the hydrolysis of phytate could result from nonspecific phosphatase or specific phytase activities (Maenz and Classen, 1998). There are several possible ways by which phytase can degrade phytate within the digestive tract of poultry: (i) intestinal phytase due to digestive secretions, (ii) endogenous phytase present in some feed ingredients, (iii) phytase originating from resident bacteria, (iv) phytase produced by exogenous microorganisms (Nys et., 1996). Some studies have reported that intestinal phytases could contribute to phytate P digestibility in pigs (Hu et al., 1996) and poultry (Maenz and Classen, 1998), but its contribution toward phytate $\mathrm{P}$ digestibility might need further studies. The presence of native phytase in some feed ingredients could degrade phytate P. High native phytase activities in cereals (except oats) and their by-products compared with legume seeds and oats and maize were found, for instance by Steiner et al. (2007), which may contribute substantially to the gastrointestinal hydrolysis of phytate in monogastrics. Table 5 shows the degradation of inositol in broilers. Steiner et al. (2007) for instance, 
Table 5 The degradation of IP6 ${ }^{1}$ under standard conditions, and at practical digestible phosphorus (DPp) and Ca levels, measured at the terminal ileum of 4 wk old broilers (Van der Klis and Blok, 1997).

\begin{tabular}{|c|c|c|}
\hline \multirow[b]{2}{*}{ Ingredient } & \multicolumn{2}{|c|}{ Degradation of I nositol-6-phosphate (\%) } \\
\hline & Standard condition ${ }^{2}$ & Practical dig. P and $\mathrm{Ca}$ level $\left.\right|^{3}$ \\
\hline \multicolumn{3}{|l|}{ Experiment 1} \\
\hline Soybean meal, solvent extract & 69 & 36 \\
\hline Peas & 38 & 28 \\
\hline
\end{tabular}

Experiment 2

\begin{tabular}{lll}
\hline Peas & 42 & 22 \\
\hline Lupins & 68 & 38 \\
\hline Maize & 29 & 11 \\
\hline Rapeseed meal (double low) & 28 & 11 \\
\hline Soybean (heat treated) & 28 & 32 \\
\hline Soybean meal, solvent extract & 50 & 36 \\
\hline Wheat & 45 & 27
\end{tabular}

${ }^{1}$ Measured as the disappearance of IP6 by means of the HPLC method (Bos et al., 1991)

${ }^{2} 1.8 \mathrm{~g}$ DPp per $\mathrm{kg}$ and $5.0 \mathrm{~g}$ Ca per $\mathrm{kg}$

${ }^{3} \mathrm{In}$ exp. 1: $3.0 \mathrm{~g} \mathrm{DPp}$ per $\mathrm{kg}$ and $8.3 \mathrm{~g}$ Ca per $\mathrm{kg}$; in exp. 2: $3.0 \mathrm{~g} \mathrm{DPp}$ per $\mathrm{kg}$ and $6.8 \mathrm{~g}$ Ca per $\mathrm{kg}$

It was shown by Kerr et al. (2000) that the hydrolysis of inositol hexaphosphate (IP6) was active in the crop not only as a result of the micro-organisms present in the crop but also because of dietary phytase, which was involved when laying hens and broilers were fed low phosphorus, corn-soybean meal diets. In addition, different phytase sources can vary in properties such as the pH optima, resistance to hydrolysis in the digestive tract and thermo-stability. The capacity of any phytase source to withstand hydrolysis along the digestive tract may affect the extent to which dietary phytates can be hydrolysed by the enzyme (Onyango et al., 2005). Phytase activity can also be influenced by the amount of dietary phosphorus fed to the poultry. A study has shown that birds can adapt to low $P$ levels in the diets by producing higher intestinal phytase activity and hence higher capacity to utilize the phytate $\mathrm{P}$ and release more P. It was found by Alaeldein (2012) that broilers that consumed Pdeficient diet $(4.0 \mathrm{~g} / \mathrm{kg} \mathrm{tP})$ with no supplemental inorganic $P$, produced $50 \%$ more phytase enzyme as compared to those fed control diets $(6.0 \mathrm{~g} / \mathrm{kg}$ tP) from 3 to 6 weeks of age. This increase in phytate phosphorus utilization could be also directly related to intestinal phytase (McCuaig et al., 1972). These results suggested that birds are very efficient in maintaining their phosphorus status.

Phytate hydrolysis in pig can occur both in the stomach and hindgut. The level of phytase present in a feed ingredient may influence the phytate degradation in the gastrointestinal tract of pigs. In a study of Schlemmer et al. (2001), a differentiation was made between intrinsic feed phytases and endogenous phytases with respect to hydrolysing phytate in the gut. Two diets $A$ and $B$, one high (control diet) and other one very low in intrinsic feed phytases were fed to the pigs. The two diets had the same composition (except that cereals in diet B have been extruded), similar concentration of total $\mathrm{P}$ (without any supplementation of $\mathrm{Pi}$ ) and of phytate hydrolysis products (IP2-IP5). Both diets differed significantly in feed phytase activity due to extrusion of the cereals of diet $B(43.1 \pm 2.1$ and $0.2 \pm 0.1$ $\mathrm{mU} / \mathrm{mg}$ protein, for diet $A$ and $B$ respectively). In the control diet, a high content of phytate hydrolysis products (IP2-IP5) $(58.1 \pm 13.8 \%)$ of total inositol phosphates was found in the gastric chyme, suggesting strong phytate degradation in the stomach of pigs fed the control diet rich in phytases. On the other hand, a content of $16.8 \pm 4.1 \%$ was reported for the extruded diet of the same total inositol phosphates IP2-IP5, indicating low phytate degradation in the stomach of the pigs. In this study, stomach was considered to be a main site of phytate degradation.

Sandberg et al. (1993), observed a reduced degradation at high dietary calcium carbonate levels in the colon but not in the stomach and small intestine when pigs were fed rapeseed meal without phytase activity. The total gastrointestinal degradation of phytate in pigs was 97,77 , and $42 \%$ when calcium intake was 4.5, 9.9, and $15 \mathrm{~g} / \mathrm{d}$, respectively. The phytate degradation in the colon could be attributed to the effects of large number of micro flora present. 
Studies have shown that transgenic pigs can secrete sufficient phytase from the salivary glands to enable efficient digestion of plant $P$ without supplemental P. A pig can secrete up to 0.5 litres of saliva during the consumption of $0.5 \mathrm{~kg}$ of dry feed (Corring, 1980). As a result, pigs demonstrating phytase in the salivary glands may supply as much as $200,000 \mathrm{U}$ of phytase to the digestive tract during the consumption of $1 \mathrm{~kg}$ of feed.

Golovan et al. (2001) detected high phytase activities in the parotid, sublingual, and sub maxillary gland; whereas low substantial activities were found in tissues from the fundus region of the stomach and from duodenum when transgenic pigs were fed soybean meal containing $53 \%$ phytate phosphorus as the sole source of phosphorus without supplementing an additional P-source. The true phosphorus digestibility in the test diets by both weanling and growing-finishing transgenic pigs approached $100 \%$, compared with approximately $50 \%$ for non-transgenic pigs. However, this activity in the saliva has been reported to diminish as age of the pig increases. In a similar study, Meidinger et al. (2013) examined growth performance of the transgenic pigs fed a diet without supplemental P during weaning, growing and finishing phases. The result showed that the transgenic pigs gained body weight during this period at similar rates to their counterpart fed a similar diet with supplemental P.

\subsection{Available phosphorus in broilers}

Variations can exist in phosphorus availability from plant feedstuffs used in formulating poultry diets and commercially used $\mathrm{P}$ supplement, which makes the knowledge of $\mathrm{P}$ bioavailability an important criteria for efficient poultry production. The amount of $\mathrm{P}$ varies not only among sources but also within each source. Available $P(a P)$ refers to the $P$ that is absorbed from the diet into the animal (i.e. feed $P$ minus $P$ within the distal ileum). Retainable $P(r P)$ is that proportion of dietary total $P$ that is deposited in the body of an animal (Rodehutscord, 2013). P in the form of orthophosphate can be absorbed principally in the upper small intestine, the duodenum, and the amount absorbed is dependent the source, Ca: $\mathrm{P}$, intestinal pH among others (Hemati et al., 2013). Some of the factors that influence the utilization of phosphorus for the various species of animals include the type of ration fed, chemical form of the element, $\mathrm{Ca}: \mathrm{P}$, age of animal, sex, plane of nutrition, interaction with other minerals and nutrients, chelating agents, other feedstuffs in the diet (especially particle size), and feed processing (Peeler, 1972).

Broilers solely rely on the presence of phytases found in the ingredients (organic or inorganic) or intestinal secretions to utilize phytate phosphorus. Over the years, special attention has been given to the use of phytase for improving phosphorus availability in poultry, which has the ability to degrade phytate, increase the nutritive value of lower quality diets with reduced excretion of nutritive matters into the environment (Broz, 1993). Other strategies include the use of High Available Phosphate Corn (HAPC). A study performed by Waldroup (1999), reported that a corn-soybean meal broiler starter diet formulated using HAPC provided approximately $22 \%$ less phytate-bond $\mathrm{P}$, and as compared to a similar diet formulated using a normal corn.

\subsection{Factors influencing phytate degradation and bioavailability of phosphorus in broilers}

\subsubsection{Dietary calcium and Phosphorus level}

Calcium ( $\mathrm{Ca}$ ) is an important mineral needed by poultry, and there is need to balance their ratio with $\mathrm{P}$ such that it will not be reactive with phytic acid molecules or in a form which can result in Ca-phytin complex formation in the small intestine. Studies have shown that phytate-P digestibility varies with the mineral content of the diet, and broilers can better utilize phytate- $P$ in the absence of Ca. Tamim et al. (2004) reported up to $69.2 \%$ phytate- $P$ utilization by broilers at the terminal ileum in the absence of $\mathrm{Ca}$ when fed corn-soybean basal diets. In line with these findings, Van der Klis and Blok (1997) reported ileal phytate degradation levels of soybean meal of $65-66 \%$ in broilers that were fed $\mathrm{Ca}$ and $\mathrm{P}$ low diets, whereas ileal phytate degradation level of soybean meal was $32 \%$ in broilers that were fed diets with practical Ca and $\mathrm{P}$ contents. 
Nevertheless, phytate degradation was significantly reduced $(25.4 \%)$ when dietary Ca levels were increased to $0.5 \%$. Increasing the level of dietary Ca beyond dietary requirements has been linked to a decreased performance in broiler, mineral retention and phytate disappearance (Edwards, 1982; Nelson et al., 1990; Schoner et al., 1993; Mitchell and Edwards, 1996; Qian et al., 1996a, b; Qian et al., 1997). Based on findings, it has been suggested that the level of Ca or nPP should be regulated to maintain the desired $\mathrm{Ca}$ and $\mathrm{P}$ ratio $(2: 1)$ in order to ascertain optimum broiler performance (Rama Rao et al., 2003). Increasing dietary Ca:aP ratio in the range of 1.43 to 3.57 in the absence of phytase can lead to significant decrease in phytate degradation, P digestibility and bone ash (Amerah et al., 2014). Possible mechanisms to decrease the possibility for Ca to form complexes with phytin could be the utilization of a competitive binding compound and the utilization of a compound that would facilitate or enhance Ca absorption (Applegate et al., 2003).

The utilization of phytate-P by poultry has been shown to be influenced by dietary Ca and P (Edwards and Veltmann, 1983; Scheirdelerm and Sell, 1987; Mohammed et al., 1991). Ca could form a precipitate with phytate in the gastrointestinal tract very easily due to its high concentration in ordinary diets (Singh, 2008). Thus, dietary Ca concentration and especially the Ca:P ratio, is an important determinant of the phytase efficacy. Taylor and Coleman (1979) reported higher apparent P absorption (20.0 vs. 14.7 and 16.5 vs. $11.4 \mathrm{mmol} / \mathrm{kg}$ body weight) for both rat and golden hamster on low Ca diet (5.1-5.2 g Ca/kg). An in vitro study by Esmaeilipour et al. (2013) reported a decrease in the amount of $P$ released from phytate from 1.19 to $0.97 \mathrm{~g} / \mathrm{kg}$ of diet when the Ca level of the diet was increased from 2 to $12 \mathrm{~g} / \mathrm{kg}$. Subba et al. (1983) found an increase in Phytate-P hydrolysis in chicks by $15 \%$ when dietary Ca level was reduced from 10.0 to $5.0 \mathrm{~g} / \mathrm{kg}$ diet.

It was found by Plumstead et al. (2008) that ileal P digestibility was decreased when dietary Ca increased from 0.47 to $1.16 \%$ when fed both commercial and low phytate soybean meal diets. Similarly, it has been reported that birds have the capacity to utilize phytate-P. However, this potential is greatly influenced by the level of $\mathrm{Ca}$ in the diet. It was shown by Tamim and Angel (2003) that addition of $\mathrm{Ca}(5.0 \mathrm{~g} / \mathrm{kg})$ and three micro-mineral sources (inorganic micro-mineral premix and micro-mineral amino acid complex premix) to a corn-soybean meal grower basal diet showed that only $\mathrm{Ca}$ had a main effect on phytate phosphorus hydrolysis. The addition of $\mathrm{Ca}$ to the diets resulted in less phytate- $\mathrm{P}$ disappearing from the intestine, regardless of micro-mineral addition $(68.6 \%$ when Ca was not added vs. $21.3 \%$ when $\mathrm{Ca}$ was added). Apparent $\mathrm{P}$ absorption followed the same trend, with $24.9 \%$ in case of the addition of $5.0 \mathrm{~g} / \mathrm{kg} \mathrm{Ca}$, compared to $65.2 \%$ when Ca was not added. A high calcium diet has been shown to affect intestinal phytase activity in broilers. Applegate et al. (2003), observed increased specific activity of intestinal phytase from 42.48 to $51.66 \mathrm{nmol} \mathrm{P}$ released $/ \mathrm{mg}$ protein when dietary Ca was reduced from 9 to $4 \mathrm{~g} / \mathrm{kg}$. The reduced intestinal phytase activity in birds fed $9 \mathrm{~g} / \mathrm{kg}$ Ca correlated with a 27\% reduction in the apparent ileal Phytate-P hydrolysis in the ileal digesta and $24 \%$ reduction in the apparent absorption of $\mathrm{P}$ down to the distal ileum, indicating an almost 1:1 relation between Phytate- $\mathrm{P}$ hydrolysis and ileal $\mathrm{P}$ absorption.

\subsubsection{Dietary vitamin $\mathrm{D}_{3}$ level}

Vitamin $\mathrm{D}_{3}$ is one of the nutrients crucial for $\mathrm{Ca}$ and $\mathrm{P}$ absorption and proper skeletal development, and their homeostasis is strongly regulated by vitamin $D_{3}$. One approach to lower the unfavourable effects of Ca on P availability in poultry may be to increase the concentration of vitamin $D$ in the diet which may increase rapidly the rate of absorption of $P$ thereby also reducing its availability to form insoluble calcium salts. Phytate- $P$ utilisation with regards to vitamin $D_{3}$ is associated to dietary levels of $\mathrm{Ca}$ and P. It was already demonstrated by Mohammed et al. (1991) that a decrease in dietary Ca level allows a greater utilization of phytate- $P$ and minimise the need for inorganic $P$ supplementation. In this study, significant increases were observed in phytate- $P$ digestibility (50-76.5\%) and $P$ retention (41.5-54\%) when the level of cholecalciferol (vitamin $D_{3}$ ) was increased from 12.5 to $1250 \mu \mathrm{g} / \mathrm{kg}(500$ to $50.000 \mathrm{IE}$ ) in a P-deficient broiler diet that was deficient in both inorganic $\mathrm{P}$ and dietary Ca. It was observed by Mitchell and Edwards (1996) that phytase, together with $1.25-(\mathrm{OH})_{2} \mathrm{D}_{3}$ had additive effects on increasing phytate $P$ retention, including bone ash in male broilers 1-21 and 0-35 days of age. In general, cholecalciferol supplementation can improve phytate- $P$ utilization particularly phytase is used and/or the level of dietary Ca is lowered. 


\subsubsection{Age of the birds}

The ability of poultry to utilize phytate $P$ increases with age (Edwards et al., 1989). Sebastian et al. (1998) stated that about one-third of the total $P$ in plant-derived ingredients is absorbable to young chicks and perhaps up to one-half is available to layers. A study by Marounek et al. (2008), reported that phytate-P utilisation increases with age in chicks and laying hens. A review by Peeler et al. (1972) indicates that phytate phosphorus is intermediate in biological availability for adult poultry, but it is very low in biological availability for young poultry. The potential to achieve this increased utilization of Phytate- $P$ with age is suggested to be the result of more endogenous phytase which is present in the gastrointestinal tract of older birds (Ravindran et al., 1995; Marounek et al., 2010). Ashton et al. (1960) reported considerable differences in P retention between two groups of growing chicks, where 6-week-old chicks retained 36-49\% of the phytate-P consumed compared with 4-week-old chicks which retained $18-19 \%$ when fed ${ }^{32} \mathrm{P}$-labelled calcium phytate diet. This is consistent with a study performed by Edwards et al. (1988), who recorded phytate retention at 7, 14, and 21 days to be 35, 47 and $59 \%$, respectively. However, there have been contradictory observations regarding phytate utilisation with age. For instance, Alaeldein (2012) found that laying hens at 32 weeks of age retained a significantly higher amount of Phytate-P compared with 52 and 72 weeks (39.5 vs. 31.3 and $36.5 \%)$. The author indicated that these result are in agreement with the fact that there is higher demand for P during the early stages of the laying cycle when egg production, egg weight and body weight are increasing.

\subsubsection{Sex of the bird}

The influence of broiler gender on phytate degradation has been investigated. A difference in sex might be related to a difference in $\mathrm{P}$ requirements, which can finally result into differences in hydrolysing phytate-P. Edwards et al. (1989) had previously reported differences between male and female broilers in the digestion of phytate-phosphorus. These authors found a pronounced effect of sex, with males utilizing $0.2-0.6 \%$ more phytate $P$ than the females. Ravindran et al. (2004) reported apparent ileal phytate-P degradation in males which was slightly higher than that of the females, although this effect was not significant (0.282 vs. 0.234). Similarly, Ziaei et al. (2007) reported a $P$ retention of 0.55 and $0.49 \mathrm{~g} / \mathrm{bird} / \mathrm{d}$ for male and female respectively, suggesting that sex can influence phytate- $P$ degradation to some extent in broilers.

\subsubsection{Soaking}

Processing of feed ingredient and addition of certain organic acids such as citric and malic acid have been shown to improve phytate- $P$ retention (Liem et al., 2008). According to Hurrell (2004), soaking or extracting in aqueous solutions can remove up to two thirds of the phytic acid by the action of endogenous phytase activity, but loss of minerals, water-extractable proteins and vitamins can also occur. This pre-treatment method of plant ingredients can have an enhancing effect on $\mathrm{P}$ retention and improve significantly the apparent absorption of $P$ (Nasi et al., 1995). Soaking a phytase treated diet was reported to improve the $\mathrm{P}$ absorption up to $15 \%$ units compared with a non-soaked diet of $11 \%$ units. A study by Newkirk and Classen (1998), suggested that effective hydrolysis of phytate in plant feed ingredients requires pre-treatment with conditions aimed to optimize phytate hydrolysis, including $\mathrm{pH}$-modification, temperature and moisture control, addition of phytase and other enzymes.

An in vitro study by Esmaeilipour et al. (2012) found that the stability of intrinsic phytase of rye, wheat and barley decreases with increasing temperature, $\mathrm{pH}$ level and time of incubation. It was reported that at $\mathrm{pH} 3$ and temperature of about 20 and $38^{\circ} \mathrm{C}$, the highest stability of intrinsic phytase was recorded which decreased as the two parameters increases to 8 and $80^{\circ} \mathrm{C}$. Soaking of a broiler diet with a citric acid solution a day prior to feeding may increase available $P$ and decrease the need of supplemental inorganic P. Esmaeilipour et al. (2013) compared two types of soaking in an in vitro incubation of four different ingredients. They showed a significant effect of a citric acid solution as compared with a water solution on the amount of released P ( $1.25 \mathrm{vs} .0 .92 \mathrm{~g} / \mathrm{kg}$ diet). As time of soaking increased, the difference in released $P$ due to soaking with citric acid in comparison with soaking with deionised water also increases. However, stability of intrinsic phytase has been reported to decrease with increased incubation time (Esmaeilipour et al., 2012). 
The difference in the amount of $\mathrm{P}$ released between soaking with citric acid solution and water after $2 \mathrm{~h}$ of soaking was $0.18 \mathrm{~g} / \mathrm{kg}$ of diet, but it increased to $0.44 \mathrm{cg} / \mathrm{kg}$ after $24 \mathrm{~h}$ of soaking. Similarly, citric acid can improve the availability of $P$ via chelating effects on divalent cations (especially $\mathrm{Ca}$ ), resulting in increased solubility and susceptibility of phytate to hydrolysis (Centeno et al., 2007).

\subsubsection{Particle size}

Uniform particle size of different grains is important for efficient poultry production. Among other benefits, the process of continued particle size reduction increases both the number of particles and the surface area per unit volume, allowing greater access to digestive enzymes (Goodband et al., 2002). It was suggested by Kilburn and Edwards (2004) that coarse soybean meal may be more efficiently utilized than fine soybean meal. These authors found interaction between SBM particle size and $\mathrm{P}$ level when tested at different dietary $\mathrm{P}$ contents $(0.7$ and $0.5 \%)$. The coarse SBM improved bone ash, gain: feed ratio and plasma $\mathrm{P}$ levels, however, the ground SBM at $0.5 \%$ resulted in low plasma dP and poor performance. A significant interaction between feed particle size and form has been reported. Kilburn and Edwards (2001), observed an improved Ca and phytate $P$ retention with a coarse maize diet, while feed efficiency was superior in a fine maize diet. A study of Ton et al. (2014) examined the effect of screen size $(1,2$ and $3 \mathrm{~mm}$ ) and microbial phytase ( 0 and 1,000 FTU/ $\mathrm{kg}$ ) on phytate degradation in maize $(100 \%)$, soybean meal $(100 \%)$ and maize-SBM $(75 \%)$ incubated in water at $38^{\circ} \mathrm{C}$. These authors found an interaction between microbial phytase and incubation time. The interaction between the screen and feed had an effect on the relative phytate degradation rate $(\mathrm{Rd})$ of microbial phytase as well as the time to decrease $50 \%$ of the phytate $\mathrm{P}(\mathrm{t})$. It was concluded that reducing the screen size from 3 to $1 \mathrm{~mm}$ increased phytate degradation rate constant (Kd) and $\mathrm{Rd}$ but decreased time in maize and maize-SBM with microbial phytase.

\subsection{Conclusions from literature}

The most important conclusions from literature regarding the factors effecting phytate degradation in broilers are:

- Broilers and their gut microbiota have a strong potential to degrade phytate in low-P and low-Ca diets.

- A high ( $7 \mathrm{~g} / \mathrm{kg}$ ) versus a low $(2 \mathrm{~g} / \mathrm{kg}$ ) dietary Ca content, and a high (3.5) versus a low (1.5) Ca: aP ratio negatively affect the level of phytate degradation, which is related to the formation of undegradable Ca-phytate complexes.

- A high $(9 \mathrm{~g} / \mathrm{kg})$ versus a low $(4 \mathrm{~g} / \mathrm{kg})$ dietary Ca content reduces the intestinal phytase activity determined in brush border vesicles.

- A moderate $(12.5 \mu \mathrm{g} / \mathrm{kg}, 500 \mathrm{IU} / \mathrm{kg})$ vs. high $(1250 \mu \mathrm{g} / \mathrm{kg}, 50.000 \mathrm{IU} / \mathrm{kg})$ dietary vitamin $D_{3}$ content reduces phytate degradation.

- $\quad$ The capacity of broilers to degrade phytate increases over age.

- Processing of ingredients, e.g. soaking in (acidified) water, contributes to phytate degradation. The level of degradation is positively related to the soaking time.

- $\quad$ Providing a coarse versus a fine maize-rich diet increases phytate degradation. 


\section{Experiments}

\subsection{Birds and management}

Four broiler experiments were performed at the research facility Carus of the Department of Animal Science in Wageningen University, The Netherlands. Experiment 3 was conducted both in Wageningen, as well as at the research facility of Schothorst Feed Research (Lelystad, The Netherlands).

Experiment 3 belonged to a ringtest, in which the recent developed protocol for determination of the precaecal digestible phosphorus content (WPSA, 2013) was tested by many research institutes all over the world. Schothorst Feed Research, which also joined this ringtest, determined within the framework of the current study in their ringtest both the precaecal $P$ digestibility and the faecal $P$ retention of the test diets.

Experiment 2, 3 and 4 were part of one overarching study, which was carried out at the same time. Initially, experiment 1 was also included in that study. Birds, however, were not able to digest the semi-synthetic phytate-free diets. Therefore, after changing the composition of the diets, experiment 1 was repeated.

A total of 801 (260 in experiment 1 and 601 in experiment 2-4) day-old male broilers Ross 308 were obtained from a commercial hatchery. The birds were vaccinated against IB+NCD (spray vaccination), weighed in groups and housed in large floor pens $\left(5 \mathrm{~m}^{2}\right)$. Wood shavings were used as bedding material. Each pen contained 2 feeding troughs and 8 nipple drinkers, and feed was supplied on egg trays for the first few days. All birds received a commercial starter diet between 0 and 14 days. The adaptation period to the experimental diets was between 14 to 21 days. The main period was from day 21 to 24. Birds were dissected at d 24, where after ileal digesta was collected. Feed and water was provided ad libitum, but to prevent selective feed intake during the main period ( $d 21$ to d24) feed was provided semi ad libitum during this period. This means that the amount of feed was adjusted in that way that the feeding troughs were empty once a day.

The parallel experiment 3 conducted at Schothorst Feed Research made use of the same experimental ringtest diets. In this experiment, 216 day-old male broilers Ross 308, obtained from a commercial hatchery, were used. In this experiment, birds were fed a commercial starter diet (total P content 5.5 $\mathrm{g} / \mathrm{kg}, \mathrm{rP}$ content $4.1 \mathrm{~g} / \mathrm{kg}$ ) including microbial phytase from day-old to day 20 , where after birds were switched to the experimental diets. In this experiment, birds were dissected at $\mathrm{d} 28$.

The temperature in the animal house was heated to $34^{\circ} \mathrm{C}$, one day prior to the start of the experiment and was gradually reduced from 34 to $29^{\circ} \mathrm{C}$ between d 1 to 7 , from 29 to $25^{\circ} \mathrm{C}$ between d 8 to 14 , from 25 to $21^{\circ} \mathrm{C}$ between d 15 to 21 , after which the temperature was constant. The first two days of life, light was continuously on (24L:0D), and from d 2 to 21 a light schedule of 18L: 6D was provided. During the main period ( $d$ 21-24), in experiment 1 to 4 a continuous lighting schedule (24L: OD) was provided, and in experiment 3 a 23L: 1D light schedule, in order to ensure a steady state condition and homogenous distribution of feed intake. Light intensity was maintained at 20 lux during the entire experiment. All dead or birds with visible deviations were removed and weighed at the moment of removal. These experiments were performed according to the guidelines of the quality management system of Carus (ASG) and Schothorst Feed Research.

\subsection{Housing}

In experiment 1 to 4 , during the first 14 days birds were housed on litter (Softcelll; $2 \mathrm{~kg} / \mathrm{m}^{2}$ ) in floor pens $\left(2.85 \mathrm{~m} \times 1.80=5.13 \mathrm{~m}^{2}, 200\right.$ birds/pen). At day 15, broilers were randomly allocated to floor pens $\left(0.875 \mathrm{~m} \times 1.1 \mathrm{~m}=0.96 \mathrm{~m}^{2}\right.$ ) with 10 (experiments 1,2 and 4 ) or 12 (experiment 3 ) birds per pen with 6 replicate pens per treatment. The pens were divided over two compartments ( $1 \times 48$ and 1 x 24 pens) of the broiler house. Pen weights were determined, thereby minimizing the differences in bird weight between pens. The differences between the highest and lowest pen weight did not exceed $3 \%$ of the average weight. The birds were placed on plastic slatted floors (J ansen Poultry Equipment, Barneveld, The Netherlands) to prevent intake of litter and faeces which might disturb the determination of nutrient digestibility. 
Perches were provided in each pen. Each pen contained a feeding trough ( $1 \mathrm{~m}$ length) and a drinking line with 2 nipples, the design of the feeding trough prevented feed spillage.

In the parallel experiment 3 of Schothorst Feed Research, birds were housed in digestibility cages ( 1 $\mathrm{m}^{2}$ ), with 12 birds per cage ( 6 replicate cages per treatment). Each cage contained a feeding trough and a drinking line with 3 nipples.

\subsection{Experimental diets}

Birds received a commercial starter diet during the first 14 days. From day 15 onwards, all birds received the experimental diets. The twelve experimental treatments were formulated and distributed over the 72 pens to provide 6 replicates. The diets were optimized for a relative low aP content (3.0 $\mathrm{g} / \mathrm{kg}$ ), except for diet 3,4 and 11 . In all diets, the ratio between Ca and total $\mathrm{P}$ was between 1.3 to 1.4 , as set by the followed protocol (Rodehutscord and WPSA, 2013). All diets were supplemented with titanium oxide $\left(\mathrm{TiO}_{2}\right)$ as the indigestible marker $(5 \mathrm{~g} / \mathrm{kg})$ and were formulated without adding exogenous phytase. All diets were provided in pelleted form.

Within the experiment four different research questions were addressed and below an overview is giving of the different diets using to answer these questions.

\subsubsection{Experiment 1: effect of non-phytate $P$ supplementation to a phytate low basal diet on $\mathrm{P}$ digestibility}

In experiment 1, the effect of non-phytate $\mathrm{P}$ supplementation to a phytate low basal diet on $\mathrm{P}$ digestibility was determined. In this experiment, 4 diets were formulated to contain incremental levels of retainable phosphorus based on CVB (2011) by replacing diamol with increasing levels of monohydrated MCP (Aliphos, Bulgaria). The dietary rP content ranged from 1.0 to $6.0 \mathrm{~g} / \mathrm{kg}$ (calculated) of the diet, thereby covering the range of 32 to $195 \%$ of the by CVB (2012) recommended $\mathrm{rP}$ supply. MCP was used as non-phytate $\mathrm{P}$ source. Limestone was added to maintain a calculated $\mathrm{Ca}$ : $\mathrm{P}$ ratio of 1.40. MCP and limestone were supplemented to the basal diets according to the treatments at the expense of diamol. The composition of ingredients and nutrients of the diets used in experiment 1 are provided in Table 6.

In this experiment, interference with phytate degradation was excluded. Therefore, this test was performed under low dietary phytate conditions $(0.85 \mathrm{~g} / \mathrm{kg})$. Because phytate is absent in animal protein, egg white powder and casein were used as the main protein and $\mathrm{P}$ source in the basal part of these diets. Based on the experiences of a previous experiment, inclusion of a minimum amount of soybean meal was necessary to provide a certain amount of dietary fibres. 
Table 6 Composition of ingredients and nutrients in the diets used in experiment 1 (in $\mathrm{g} / \mathrm{kg}$ as fed unless otherwise indicated). Calculated concentrations of avaiable P (aP; g/kg product) were based on CVB (2011) table values, derived from faecal digestibility studies.

\begin{tabular}{|c|c|c|c|c|}
\hline Item & $\begin{array}{l}1.0 \mathrm{rP} \\
\text { (basal) }\end{array}$ & $2.7 \mathrm{rP}$ & $4.3 \mathrm{rP}$ & $6.0 \mathrm{rP}$ \\
\hline \multicolumn{5}{|l|}{ Ingredients } \\
\hline Maize starch gelatinised & 220.0 & 220.0 & 220.0 & 220.0 \\
\hline Native maize starch & 168.3 & 168.3 & 168.3 & 168.3 \\
\hline Soybean meal & 110.0 & 110.0 & 110.0 & 110.0 \\
\hline Egg white powder & 100.0 & 100.0 & 100.0 & 100.0 \\
\hline Sugar & 100.0 & 100.0 & 100.0 & 100.0 \\
\hline Casein & 100.0 & 100.0 & 100.0 & 100.0 \\
\hline Oat hulls & 70.0 & 70.0 & 70.0 & 70.0 \\
\hline Diamol & 70.0 & 57.9 & 45.8 & 33.4 \\
\hline Soya oil & 40.0 & 40.0 & 40.0 & 40.0 \\
\hline Premix $^{1}$ & 5.0 & 5.0 & 5.0 & 5.0 \\
\hline Titanium dioxide & 5.0 & 5.0 & 5.0 & 5.0 \\
\hline Limestone $^{2}$ & 3.3 & 6.1 & 8.9 & 11.7 \\
\hline Monocalcium phosphate ${ }^{3}$ & 1.7 & 11.1 & 20.5 & 30.0 \\
\hline Sodium chloride & 0.2 & 0.1 & 0.1 & 0.1 \\
\hline Potassium carbonate & 3.6 & 3.6 & 3.6 & 3.6 \\
\hline Sodium bicarbonate & 1.0 & 1.0 & 1.0 & 1.1 \\
\hline Magnesium oxide & 1.0 & 1.0 & 0.9 & 0.9 \\
\hline L-Arginine & 0.9 & 0.9 & 0.9 & 0.9 \\
\hline \multicolumn{5}{|l|}{ Nutrients calculated } \\
\hline Crude protein & 228 & 228 & 228 & 228 \\
\hline Crude fibre & 25 & 25 & 25 & 25 \\
\hline Crude fat & 45 & 45 & 45 & 45 \\
\hline ME (kcal/kg) & 12.74 & 12.74 & 12.74 & 12.74 \\
\hline \multicolumn{5}{|l|}{ Nutrients analysed } \\
\hline Dry matter & 896 & 892 & 893 & 896 \\
\hline Ash & 88 & 87 & 84 & 83 \\
\hline $\mathrm{Ca}$ & 2.45 & 5.01 & 7.50 & 10.04 \\
\hline Phosphorus, total & 2.26 & 4.51 & 6.47 & 8.60 \\
\hline $\mathrm{Ca}: \mathrm{P}$ & 1.08 & 1.11 & 1.16 & 1.17 \\
\hline Phytate P & 0.85 & 0.85 & 0.83 & 0.85 \\
\hline $\mathrm{Ti}$ & 3.05 & 3.09 & 3.03 & 3.10 \\
\hline
\end{tabular}

${ }^{1}$ Premix (provided per $\mathrm{kg}$ of diet): $4.1 \mathrm{mg}$ retinyl acetate, $60 \mu \mathrm{g}$ cholecalciferol, $45.5 \mathrm{mg}$ dl-a-tocopherol, $1.5 \mathrm{mg}$ menadione, $2.0 \mathrm{mg}$ thiamine, $7.5 \mathrm{mg}$ riboflavine, $10.0 \mathrm{mg}$ d-pantothenic acid, $35 \mathrm{mg}$ niacin, $2,000 \mu \mathrm{g}$ biotin, $20 \mu \mathrm{g}$ cyanocobalamin, $1.0 \mathrm{mg}$ folic acid, $3.5 \mathrm{mg}$ pyridoxine- $\mathrm{HCl}$ $460 \mathrm{mg}$ choline chloride, $80 \mathrm{mg} \mathrm{Fe}\left(\right.$ as $\mathrm{FeSO}_{4} \cdot \mathrm{H}_{2} \mathrm{O}$ ), $12 \mathrm{mg} \mathrm{Cu}$ (as $\mathrm{CuSO}_{4} \cdot 5 \mathrm{H}_{2} \mathrm{O}$ ), $60 \mathrm{mg} \mathrm{Zn} \mathrm{(as} \mathrm{ZnSO} \cdot \mathrm{H}_{2} \mathrm{O}$ ), $85 \mathrm{mg} \mathrm{Mn} \mathrm{(as} \mathrm{MnO),} 0.4 \mathrm{mg} \mathrm{Co} \mathrm{(as}$ $\mathrm{CoSO}_{4} \cdot 7 \mathrm{H}_{2} \mathrm{O}$ ), $0.8 \mathrm{mg} \mathrm{I}$ (as $\mathrm{KI}$ ), $0.15 \mathrm{mg} \mathrm{Se}\left(\mathrm{as} \mathrm{Na}_{2} \mathrm{SeO}_{3}\right.$ ) and $125 \mathrm{mg}$ anti-oxidant.

${ }^{2}$ Grinding fineness of limestone less than $250 \mu \mathrm{m}$.

${ }^{3}$ Analyzed composition of monocalcium phosphate $(\mathrm{g} / \mathrm{kg})$ : moisture 17, ash 806, phosphor 208 and calcium 182.

\subsubsection{Experiment 2: effect of non-phytate $\mathrm{P}$ supplementation to a phytate-rich basal diet on $\mathrm{P}$ digestibility}

In experiment 2, the effect of non-phytate $\mathrm{P}$ supplementation to a phytate-rich basal diet on $\mathrm{P}$ digestibility was determined in the range of 1.5 to $4.5 \mathrm{~g} / \mathrm{kg} \mathrm{rP}$ (calculated). MCP was used as nonphytate $P$ source. Limestone was used to maintain a calculated Ca: P ratio of 1.40. MCP was supplemented at the exchange of native maize starch. The composition of ingredients and nutrients of the diets used in experiment 2 are provided in Table 7. 
Table 7 Composition of ingredients and nutrients in the diets used in experiment 2 (in $\mathrm{g} / \mathrm{kg}$ as fed unless otherwise indicated). Calculated concentrations of avaiable $P$ ( $a P ; \mathrm{g} / \mathrm{kg}$ product) were based on CVB (2011) table values, derived from faecal digestibility studies.

\begin{tabular}{|c|c|c|c|}
\hline I tem & 1.5 rP (basal) & $3.0 \mathrm{rP}$ & $4.5 \mathrm{rP}$ \\
\hline \multicolumn{4}{|l|}{ Ingredients } \\
\hline Native maize starch & 448.6 & 437.5 & 426.3 \\
\hline Sugar & 80.0 & 80.0 & 80.0 \\
\hline Soya oil & 30.0 & 30.0 & 30.0 \\
\hline Egg white powder & 18.0 & 18.0 & 18.0 \\
\hline Premix $^{1}$ & 5.0 & 5.0 & 5.0 \\
\hline Titanium oxide & 5.0 & 5.0 & 5.0 \\
\hline Salt & 3.0 & 3.0 & 3.0 \\
\hline DL-Methionine & 2.7 & 2.7 & 2.7 \\
\hline L-Threonine & 0.3 & 0.3 & 0.3 \\
\hline Crude fat & 39.8 & 39.7 & 39.7 \\
\hline Ash & 44.0 & 55.0 & 66.1 \\
\hline ME (Kcal/kg) & 2,994 & 2,954 & 2,915 \\
\hline $\mathrm{rP}$ & 1.5 & 3.0 & 4.5 \\
\hline \multicolumn{4}{|l|}{ Analysed nutrients } \\
\hline DM & 105 & 103 & 105 \\
\hline $\mathrm{Ca}$ & 4.4 & 6.8 & 9.2 \\
\hline Phosphorus, total & 3.2 & 5.3 & 7.3 \\
\hline $\mathrm{Ca}: \mathrm{P}$ & 1.38 & 1.28 & 1,26 \\
\hline Phytate P & 1.5 & 1.6 & 1.7 \\
\hline
\end{tabular}

${ }^{1}$ Premix (provided per $\mathrm{kg}$ of diet): $4.1 \mathrm{mg}$ retinyl acetate, $60 \mu \mathrm{g}$ cholecalciferol, $45.5 \mathrm{mg}$ dl-a-tocopherol, $1.5 \mathrm{mg}$ menadione, $2.0 \mathrm{mg}$ thiamine, $7.5 \mathrm{mg}$ riboflavine, $10.0 \mathrm{mg}$ d-pantothenic acid, $35 \mathrm{mg}$ niacin, 2,000 $\mu \mathrm{g}$ biotin, $20 \mu \mathrm{g}$ cyanocobalamin, $1.0 \mathrm{mg}$ folic acid, $3.5 \mathrm{mg}$ pyridoxine- $\mathrm{HCl}$ $460 \mathrm{mg}$ choline chloride, $80 \mathrm{mg} \mathrm{Fe}\left(\right.$ as $\mathrm{FeSO}_{4} \cdot \mathrm{H}_{2} \mathrm{O}$ ), $12 \mathrm{mg} \mathrm{Cu}$ (as $\mathrm{CuSO}_{4} \cdot 5 \mathrm{H}_{2} \mathrm{O}$ ), $60 \mathrm{mg} \mathrm{Zn} \mathrm{(as} \mathrm{ZnSO}_{4} \cdot \mathrm{H}_{2} \mathrm{O}$ ), $85 \mathrm{mg} \mathrm{Mn} \mathrm{(as} \mathrm{MnO),} 0.4 \mathrm{mg} \mathrm{Co}($ as $\mathrm{CoSO}_{4} \cdot 7 \mathrm{H}_{2} \mathrm{O}$ ), $0.8 \mathrm{mg} \mathrm{I}$ (as $\mathrm{KI}$ ), $0.15 \mathrm{mg} \mathrm{Se}\left(\right.$ as $\mathrm{Na}_{2} \mathrm{SeO}_{3}$ ) and $125 \mathrm{mg}$ anti-oxidant.

\subsubsection{Experiment 3: effect of phytate P supplementation to a phytate-rich basal diet on $\mathrm{P}$ digestibility}

In experiment 3 , the effect of phytate $\mathrm{P}$ supplementation to a phytate-rich basal diet on $\mathrm{P}$ digestibility was investigated. Soybean meal was used as the major protein source, as well as the only $P$ source. Limestone was used to maintain a calculated Ca: $P$ ratio of 1.40. Soybean meal was supplemented at the exchange of native maize starch. The composition of ingredients and nutrients of the diets used in experiment 3 are provided in Table 8. In experiment 2 and 3, the same basal diet was used. 
Table 8 Composition of ingredients and nutrients in the diets used in experiment 3 (in $\mathrm{g} / \mathrm{kg}$ as fed unless otherwise indicated). Calculated concentrations of avaiable $P$ (aP; $\mathrm{g} / \mathrm{kg}$ product) were based on CVB (2011) table values, derived from faecal digestibility studies.

\begin{tabular}{|c|c|c|c|}
\hline I tem & 1.5 rP (basal) & $1.8 \mathrm{rP}$ & $2.1 \mathrm{rP}$ \\
\hline \multicolumn{4}{|l|}{ Ingredients } \\
\hline Native maize starch & 448.6 & 336.6 & 224.6 \\
\hline Sugar & 80.0 & 80.0 & 80.0 \\
\hline Soya oil & 30.0 & 30.0 & 30.0 \\
\hline Egg white powder & 18.0 & 18.0 & 18.0 \\
\hline Titanium oxide & 5.0 & 5.0 & 5.0 \\
\hline Salt & 3.0 & 3.0 & 3.0 \\
\hline DL-Methionine & 2.7 & 2.7 & 2.7 \\
\hline L-Threonine & 0.3 & 0.3 & 0.3 \\
\hline \multicolumn{4}{|l|}{ Calculated nutrients } \\
\hline Ash & 44.0 & 53.0 & 62.0 \\
\hline ME (Kcal/kg) & 2,994 & 2,809 & 2,624 \\
\hline $\mathrm{rP}$ & 1.5 & 1.8 & 2.1 \\
\hline \multicolumn{4}{|l|}{ Analysed nutrients } \\
\hline DM & 105 & 104 & 106 \\
\hline $\mathrm{Ca}$ & 4.4 & 5.6 & 6.3 \\
\hline Phosphorus, total & 3.2 & 4.0 & 4.7 \\
\hline $\mathrm{Ca}: \mathrm{P}$ & 1.38 & 1.40 & 1.34 \\
\hline Phytate P & 1.5 & 1.9 & 2.2 \\
\hline Titanium & 2.91 & 2.92 & 2.95 \\
\hline
\end{tabular}

${ }^{1}$ Premix (provided per $\mathrm{kg}$ of diet): $4.1 \mathrm{mg}$ retinyl acetate, $60 \mu \mathrm{g}$ cholecalciferol, $45.5 \mathrm{mg}$ dl-a-tocopherol, $1.5 \mathrm{mg}$ menadione, $2.0 \mathrm{mg}$ thiamine, $7.5 \mathrm{mg}$ riboflavine, $10.0 \mathrm{mg}$ d-pantothenic acid, $35 \mathrm{mg}$ niacin, 2,000 $\mu \mathrm{g}$ biotin, $20 \mu \mathrm{g}$ cyanocobalamin, $1.0 \mathrm{mg}$ folic acid, $3.5 \mathrm{mg}$ pyridoxine- $\mathrm{HCl}$ $460 \mathrm{mg}$ choline chloride, $80 \mathrm{mg} \mathrm{Fe}\left(\right.$ as $\mathrm{FeSO}_{4} \cdot \mathrm{H}_{2} \mathrm{O}$ ), $12 \mathrm{mg} \mathrm{Cu}$ (as CuSO${ }_{4} \cdot 5 \mathrm{H}_{2} \mathrm{O}$ ), $60 \mathrm{mg} \mathrm{Zn} \mathrm{(as} \mathrm{ZnSO}_{4} \cdot \mathrm{H}_{2} \mathrm{O}$ ), $85 \mathrm{mg} \mathrm{Mn} \mathrm{(as} \mathrm{MnO),} 0.4 \mathrm{mg} \mathrm{Co} \mathrm{(as}$ $\mathrm{CoSO}_{4} \cdot 7 \mathrm{H}_{2} \mathrm{O}$ ), $0.8 \mathrm{mg}$ I (as KI), $0.15 \mathrm{mg} \mathrm{Se}\left(\right.$ as $\mathrm{Na}_{2} \mathrm{SeO}_{3}$ ) and $125 \mathrm{mg}$ anti-oxidant.

\subsubsection{Experiment 4: effect of dietary structure to a phytate-rich basal diet on $\mathrm{P}$ digestibility}

In experiment 4, the effect of coarse oat hull supplementation to a phytate-rich basal diet on $\mathrm{P}$ digestibility was tested. Coarseness of the diet was increased by replacing $50 \mathrm{~g} / \mathrm{kg}$ maize starch by coarse oat hulls. The composition of ingredients and nutrients of the diets used in experiment 4 are provided in Table 9. In experiment 4, the same basal diet was used as in experiment 2 and 3. 
Table 9 Composition of ingredients and nutrients in the diets used in experiment 4 (in $\mathrm{g} / \mathrm{kg}$ as fed unless otherwise indicated). Calculated concentrations of avaiable $P$ ( $a P ; \mathrm{g} / \mathrm{kg}$ product) were based on CVB (2011) table values, derived from faecal digestibility studies.

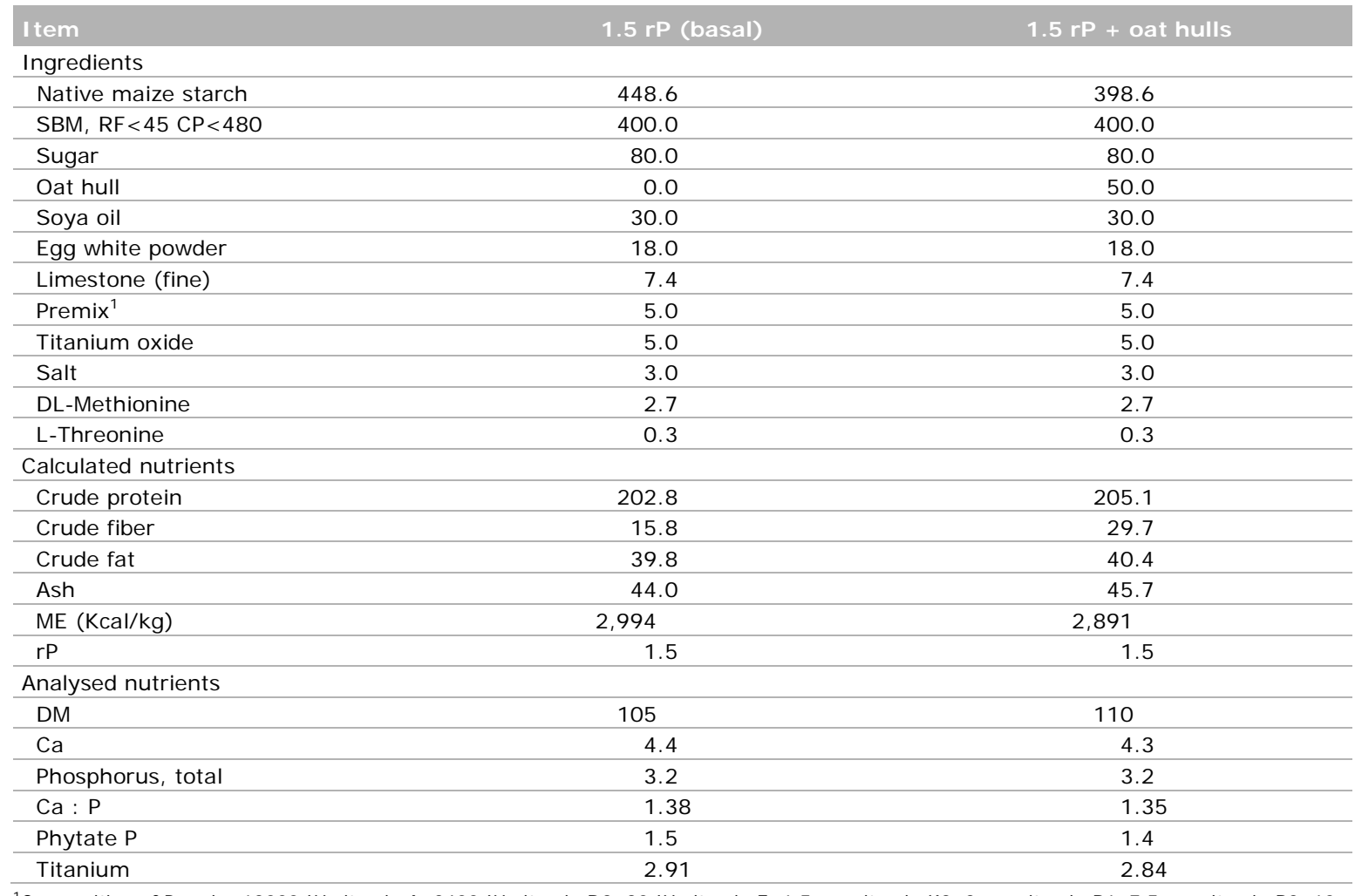

${ }^{1}$ Composition of Premix: 12000 IU vitamin A, 2400 IU vitamin D3, 30 IU vitamin E, $1.5 \mathrm{mg}$ vitamin K3, 2 mg vitamin B1, 7.5 mg vitamin B2, 10 $\mathrm{mg}$ d-pantothenic acid, $35 \mathrm{mg}$ niacin amide, $200 \mu \mathrm{g}$ biotin, $20 \mu \mathrm{g}$ vitamin B12, $1 \mathrm{mg}$ folic acid, $3.5 \mathrm{mg}$ vitamin B6, $460.83 \mathrm{mg}$ choline chloride, $80 \mathrm{mg} \mathrm{Fe}\left(\right.$ as $\mathrm{FeSO}_{4} \cdot \mathrm{H}_{2} \mathrm{O}$ ), $12 \mathrm{mg} \mathrm{Cu}\left(\right.$ as $\mathrm{CuSO}_{4} \cdot 5 \mathrm{H}_{2} \mathrm{O}$ ), $60 \mathrm{mg} \mathrm{Zn}$ (as $\mathrm{ZnSO}_{4} \cdot \mathrm{H}_{2} \mathrm{O}$ ), $85 \mathrm{mg} \mathrm{Mn} \mathrm{(as} \mathrm{MnO),} 0.4 \mathrm{mg} \mathrm{Co} \mathrm{(as} \mathrm{CoSO} \cdot 7 \mathrm{H}_{2} \mathrm{O}$ ), $0.8 \mathrm{mg} \mathrm{I}$ (as $\mathrm{KI}$ ), $0.1 \mathrm{mg} \mathrm{Se}\left(\right.$ as $\mathrm{Na}_{2} \mathrm{SeO}_{3}$ ) and $50 \mathrm{mg}$ anti-oxidant. Containing $250 \mathrm{~g} / \mathrm{kg}$ chromium oxide and $750 \mathrm{~g} / \mathrm{kg}$ maize starch.

An overall overview of al treatments is presented in Table 10.

Table 10 Overview of al treatments applied in experiment 1 to 4 .

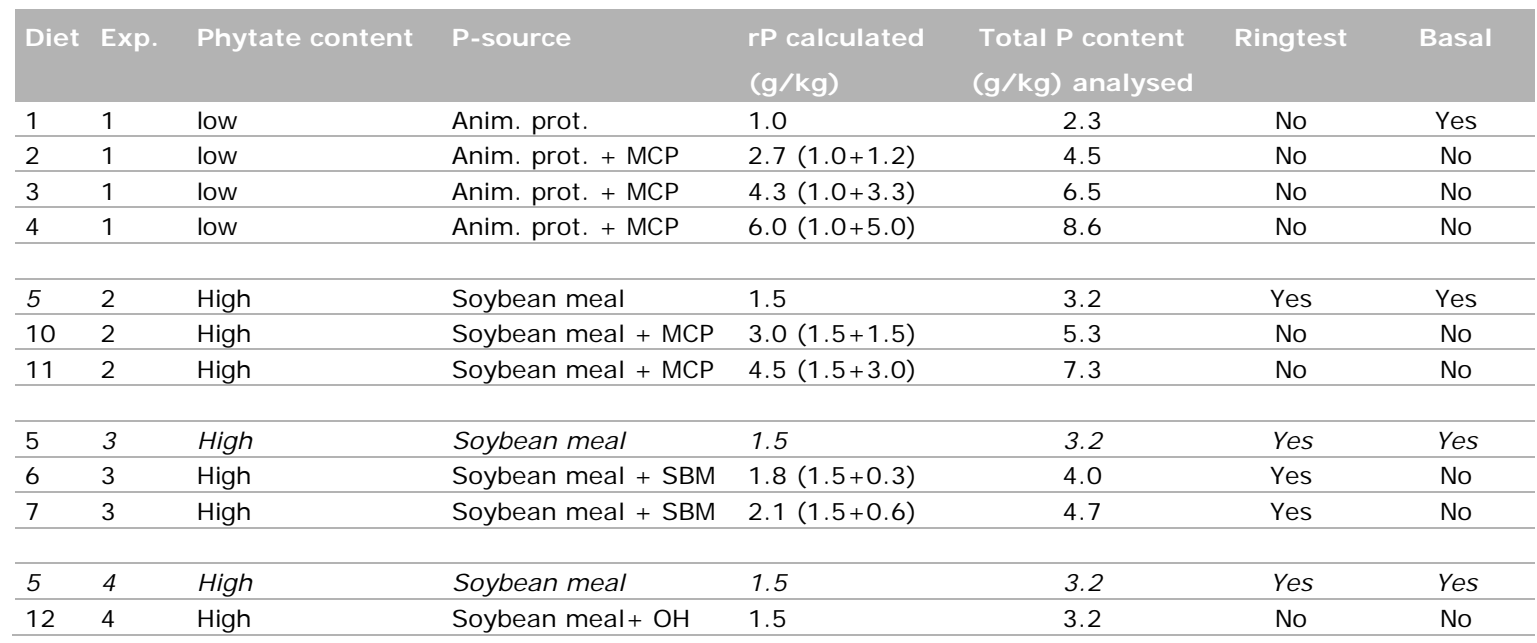

\subsection{Observations}

\subsubsection{Performance}

Body weight of birds per pen was determined at 14 and 24 days of age. Feed intake per pen was determined at 24 days of age (provided feed minus remaining feed at 24 days of age). 
Body weight of dead or culled birds was also recorded. Body weight gain (BWG), and feed conversion ratio (FCR), and mortality were calculated over the entire experimental period (d14 - d24).

\subsubsection{Dissection and sample collection}

At 24 days of age, all birds were euthanized by an intravenous injection of T61 (an aqueous solution containing (in mg per $\mathrm{ml}$ ) embutramide, 200; mebezoniumiodide, 50; tetracainehydrochloride, 5). Approximately 20-30 minutes before euthanization, the birds were anesthetized by a mixture of Sedamun and Ketamine (5:3) via injection in the breast muscle (dosage: $1 \mathrm{ml} / \mathrm{kg} \mathrm{BW}$ ). Subsequently, the chest cavity and the abdomen were opened and the small intestine was ligated and removed from the bird. The content of the terminal part of the ileum, defined as the terminal $1 / 3$ of the ileum (length approx. 12 - $15 \mathrm{~cm}$ ), was collected from all birds in a cage. The ileal content (=digesta) was collected by gently flushing the gut segment with distilled water into a plastic container. The digesta of all animals per pen were pooled and immediately after collection frozen and stored at -20oC until further analysis. The digesta was collected in the order of cage numbering. Digesta samples were freeze dried and ground $(0.5 \mathrm{~mm})$ by Nutricontrol, Veghel, The Netherlands.

In the part of experiment 3 conducted by SFR, excreta was semi-quantitatively collected once a day during 7 hours at day 25, 26 and 27. At day 28 the birds were euthanized by intracardiac injection of $\mathrm{T} 61$ ( $1 \mathrm{mml} / \mathrm{kg} \mathrm{BW})$. In a procedure similar to the other experiments, ileal content was collected from the terminal half of the ileum starting $2 \mathrm{~cm}$ proximal of the ileal-caecal junction. All samples were freeze dried and ground ( $1 \mathrm{~mm}$ ) and analysed by SFR.

\subsubsection{Chemical analysis and calculations}

Diets and ileal digesta of experiment 1, 2, 3 (Wageningen study) and 4 were analysed by Nutricontrol for DM (ISO 6496, 1998a), Ca and P (ISO 11885, 1998b), phytate, and Titanium (Van Bussel et al., 2010). Diets and digesta of the part of experiment 3 conducted by SFR were analysed for by SFR for DM (ISO 6496), Ca (AAS ISO6869:2001), P (ISO6491: 1999) and Titanium (Colorimetric method measured at $407 \mathrm{~nm}$.; method based on Short et al., 1996): Determination of titanium dioxide added as an inert marker in chicken digestibility studies. Animal Feed Science Technology, 59:215-221).

The phytate content is defined as the difference in inorganic $\mathrm{P}$ content before and after incubation of a sample with an overdose of microbial phytase. The analytical method for determination of phytate dephosphorylation ('phytase') activity is based on the colour that is formed upon the reaction of molybdate with the amount of inorganic $P$ released from phytate after incubation of the sample with microbial phytase in an citrate acid buffer solution of pH 2.5 (Marounek et al., 2011). Inorganic $P$ is responsible for the decolouration of ammonium molybdate. Colour was measured in a spectrophotometer at $820 \mathrm{~nm}$ and compared with a calibration series. The increased concentration of $\mathrm{P}$ during the 60 min incubation was attributed to phytate de-phosphorylation activity. A unit of this activity $(U)$ is defined as the activity that liberates $P$ at a rate of $1 \mu \mathrm{mol} / \mathrm{min}$.

The precaecal digestibility of $\mathrm{P}$, and $\mathrm{Ca}$, and the level of phytate degradation were calculated as:

$Y(\%)=100-\left[100 \times\left(\mathrm{Ti}_{\text {diet }} \times\right.\right.$ Nutrient $\left._{\text {digesta }}\right) /\left(\right.$ Ti $_{\text {digesta }} \times$ Nutrient $\left.\left._{\text {diet }}\right)\right]$

where $\mathrm{Ti}_{\text {diet }}$ and $\mathrm{Ti}_{\text {digesta }}$ are the analysed concentrations of $\mathrm{Ti}$ in the diet and digesta ( $\left.\mathrm{g} / \mathrm{kg} \mathrm{DM}\right)$,

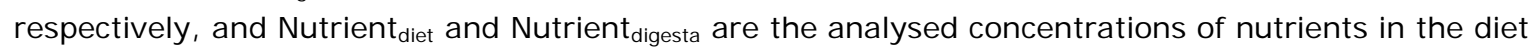
and digesta or excreta, respectively. The precaecal digestible $P(\mathrm{pcdP})$ content $(\mathrm{g} / \mathrm{kg})$ was calculated as the pcdP digestibility $(\%) \times \mathrm{P}$-content $(\mathrm{g} / \mathrm{kg}) / 100$. Likewise, the precaecal digestible Ca content was calculated.

The non-phytate P (NPP) content was calculated by the difference between tP and PP. 


\subsection{Statistical analysis}

Each pen was of birds was considered as experimental unit. The response to increasing aP supply and data obtained from each of the treatment were subjected to analysis by one-way Anova and separated by Duncan test. Probability was considered significant at $\mathrm{P}<0.05$.

Pen was the experimental unit, and statistical analyses were carried out using Genstat, 16th edition. Because in experiment 1 a significant quadratic effect $(P<0.001)$ in the response of pcdP to dietary $P$ content was observed, a broken stick regression analysis was carried out to estimate the relationship between $\mathrm{pcdP}$ and $\mathrm{P}(\mathrm{g} / \mathrm{kg})$ using the R2Lines procedure of Genstat. This broken stick model included an intercept, two slopes and a break point value. The estimated slopes represent the digestibility of $P$ at inclusion levels below and above the breakpoint.

Performance characteristics were analysed using ANOVA with treatment as fixed effect. Digestibility of Ca and P of the supplemented MCP and soybean meal were determined as described in the WPSA (2013) protocol for $P$ using a multiple linear regression model between pcdP content and added dietary $\mathrm{P}$-content including a common intercept value for all products and allowing separate regression coefficients for the products tested using the regression procedure in Genstat. 


\section{$4 \quad$ Results}

\subsection{Exp. 1: effect of nPP supplementation to a PP-low basal diet}

One statistically determined outlier value for the lowest dietary $\mathrm{P}$ level was removed from the dataset and 3 outlier values for the highest dietary $P$ level were removed from the dataset. before fitting the broken stick model. The 3 outlier observations for the highest dietary $\mathrm{P}$ level had negative pcdCa digestibility values.

Figure 2, which provided the broken stick relationship between pcdP content $(\mathrm{g} / \mathrm{kg})$ and dietary $P$ $(\mathrm{g} / \mathrm{kg})$ as analysed for the results in experiment 1 , shows that $98 \%$ of variation in pcdP content could be explained by the broken stick model. The pcdP digestibility of MCP, reflected by the slope, was estimated to be $88.0 \pm 5.16 \%$ before the break point value at a dietary $P$ level of $5.8 \pm 0.28 \mathrm{~g} / \mathrm{kg}$, and $20.1 \pm 7.35 \%$ after this break point value. The performance characteristics are provided in Table 11.

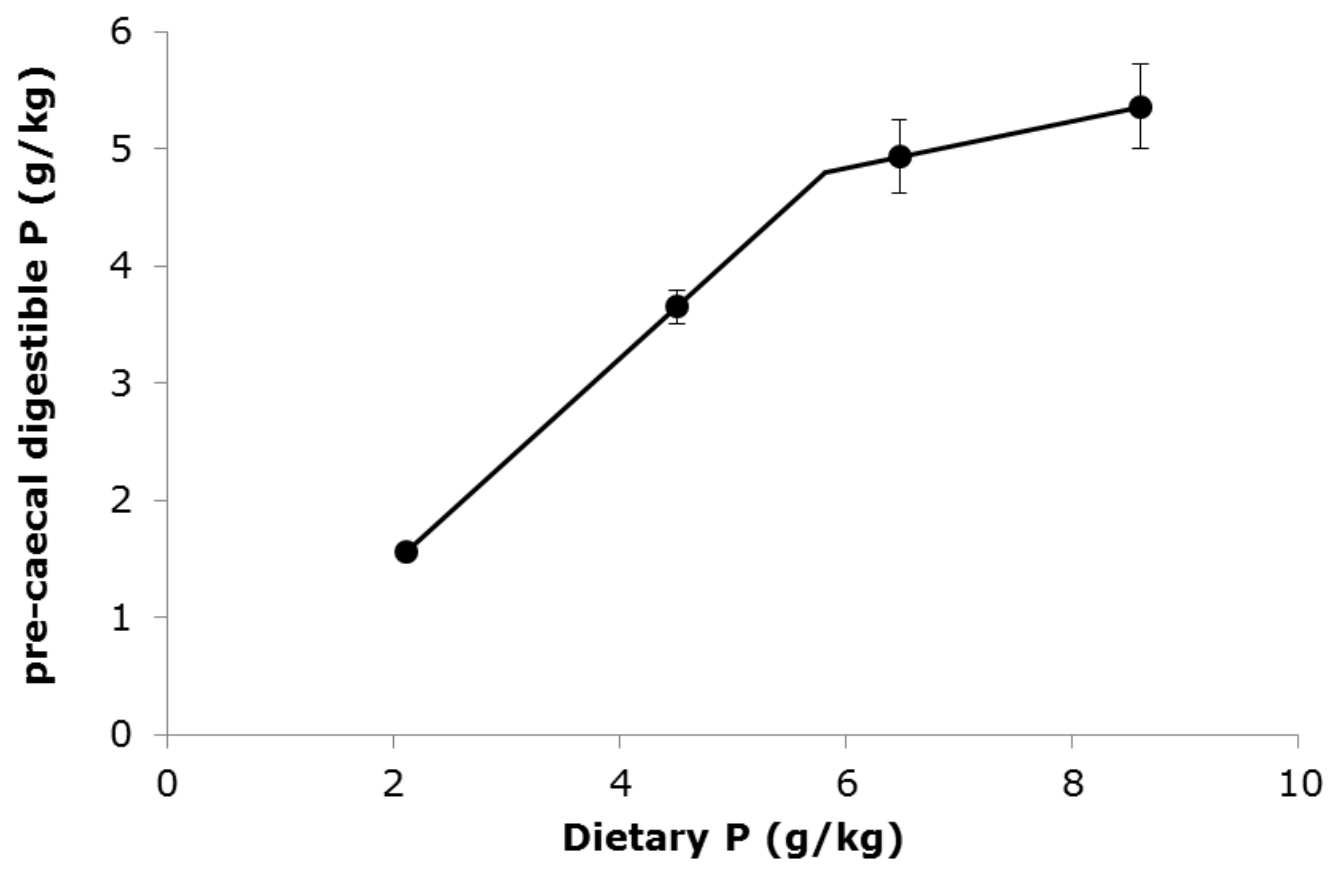

Figure 2 Relationship between precaecal digestible P concentration in broiler diets ( pcdP; g/kg) (treatments means and standard deviation) and dietary $P$ content $(\mathrm{g} / \mathrm{kg}$ ) analysed with a broken stick regression model represented by the lines. Goodness of fit of the model: $\mathrm{R}^{2}$ $=0.979$ and $\mathrm{SE}=0.221$. Parameter estimates: break point value of precaecal digestible $\mathrm{P}=4.80 \pm 0.168 \mathrm{~g} / \mathrm{kg}$ and dietary $\mathrm{P}=5.81 \pm 0.284 \mathrm{~g} / \mathrm{kg}$, slope before break point $=$ $0.880 \pm 0.0516$, slope after break point $=0.201 \pm 0.0735$.

Table 11 Performance characteristics of broilers in experiment 1 from day 14 until day 24 supplied with diets varying in retainable $\mathrm{P}(\mathrm{rP} ; \mathrm{g} / \mathrm{kg}$ product).

\begin{tabular}{lllllll} 
& $\begin{array}{l}1.0 \mathrm{rP} \\
\text { (basal) }\end{array}$ & $2.7 \mathrm{rP}$ & $4.3 \mathrm{rP}$ & $6.0 \mathrm{rP}$ & SEM & P-value \\
BW day $14(\mathrm{~g})$ & 471 & 470 & 466 & 465 & 4.2 & 0.476 \\
\hline BW day 24 $(\mathrm{g})$ & $1136^{\mathrm{b}}$ & $1286^{\mathrm{a}}$ & $1269^{\mathrm{a}}$ & $1266^{\mathrm{a}}$ & 23.7 & $<0.001$ \\
\hline ADG (g/d) & $66.5^{\mathrm{b}}$ & $81.7^{\mathrm{a}}$ & $80.3^{\mathrm{a}}$ & $80.0^{\mathrm{a}}$ & 2.27 & $<0.001$ \\
\hline ADFI (g/d) & $87.0^{\mathrm{b}}$ & $109.7^{\mathrm{a}}$ & $108.8^{\mathrm{a}}$ & $108.7^{\mathrm{a}}$ & 2.65 & $<0.001$ \\
\hline Feed:gain (g/g) & 1.311 & 1.345 & 1.355 & 1.358 & 0.0276 & 0.286 \\
\hline Mortality $(\%)$ & 0.0 & 0.0 & 1.7 & 0.0 & 0.79 & 0.359 \\
\hline
\end{tabular}


The $r P$ level had a significant $(P<0.001)$ effect on BW at day 24, ADG and ADFI. Birds receiving the lowest retainable P $(\mathrm{rP} ; \mathrm{g} / \mathrm{kg}$ ) level diet had lower BW at day 24, lower ADG, and lower ADFI compared to birds receiving the other diets with $\mathrm{rP}$ levels ranging from 2.7 to $6.0 \mathrm{~g} / \mathrm{kg}$. No differences in BW, ADG and ADFI were observed between the diets with rP levels ranging from 2.7 to $6.0 \mathrm{~g} / \mathrm{kg}$. Feed:gain ratio and mortality were not affected by dietary treatments. The pcdP and pcdCa digestibility values, the level of phytate degradation of the diets, and the contents of aP and aCa of the diets are shown in Table 12.

Table 12 Precaecal diet digestibility (\%) of $\mathrm{P}$, and $\mathrm{Ca}$, phytate degradation, and the contents of available $P$ and available $\mathrm{Ca}(\mathrm{g} / \mathrm{kg})$ in experiment 1 with diets varying in retainable $\mathrm{P}$.

\begin{tabular}{lcccc|cc} 
& $\begin{array}{c}1.0 \mathrm{rP} \\
\text { (basal) }\end{array}$ & $2.7 \mathrm{rP}$ & $4.3 \mathrm{rP}$ & $6.0 \mathrm{rP}$ & SEM & \\
\hline $\mathrm{P}$ & $73.5^{\mathrm{b}}$ & $81.2^{\mathrm{a}}$ & $76.3^{\mathrm{ab}}$ & $62.4^{\mathrm{c}}$ & 2.09 & $<0.001$ \\
\hline $\mathrm{Ca}$ & $65.2^{\mathrm{a}}$ & $69.3^{\mathrm{a}}$ & $48.1^{\mathrm{b}}$ & $32.1^{\mathrm{b}}$ & 5.96 & $<0.001$ \\
\hline Phytate & 90.8 & 90.0 & 86.0 & 86.1 & 2.61 & 0.193 \\
\hline Available P content & $1.6^{\mathrm{d}}$ & $3.7^{\mathrm{c}}$ & $4.9^{\mathrm{b}}$ & $5.4^{\mathrm{a}}$ & 0.18 & $<0.001$ \\
\hline Available Ca content & $1.4^{\mathrm{b}}$ & $3.2^{\mathrm{a}}$ & $3.5^{\mathrm{a}}$ & $3.6^{\mathrm{a}}$ & 1.23 & 0.006 \\
\hline
\end{tabular}

The $\mathrm{rP}$ level had a significant $(\mathrm{P}<0.001)$ effect on $\mathrm{pcdP}$ and $\mathrm{pcdCa}$ digestibility, whereas the level of phytate degradation was not affected by rP level. The pcdP digestibility of the $6.0 \mathrm{rP}$ diet was lower compared to the other $\mathrm{rP}$ levels. The pcdCa digestibility of the 1.0 and $2.7 \mathrm{rP}$ diets were higher than the 4.5 and $6.0 \mathrm{rP}$ diets. Dietary aP contents linearly increased with increasing rP contents from 1.6 to $5.4 \mathrm{~g} / \mathrm{kg}$. The aCa content of the $1.0 \mathrm{rP}$ diet was reduced $(1.4 \mathrm{~g} / \mathrm{kg})$ compared to the aCa content of the other 3 diets, which were not different among themselves.

\subsection{Experiment 2: effect of nPP supplementation to a PP- rich basal diet}

Figure 3, which provided the linear relationship between pcdP content $(\mathrm{g} / \mathrm{kg})$ and dietary $P(\mathrm{~g} / \mathrm{kg})$ as analysed for the results in experiment 2 , shows that $97 \%$ of variation in pcdP content could be explained by the linear regression model. The pcdP digestibility of MCP, reflected by the slope, was estimated to be $46.8 \pm 2.0 \%$.

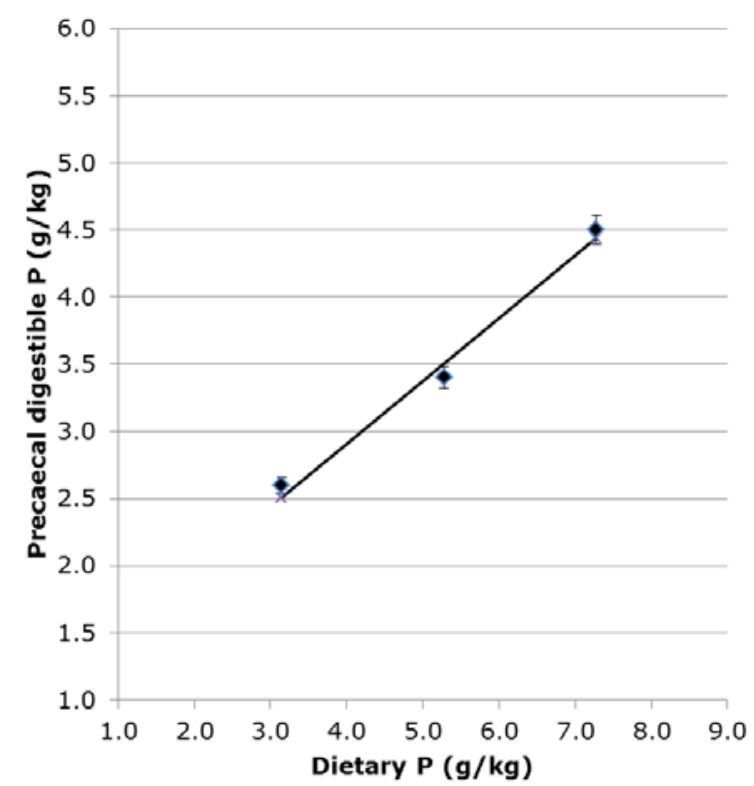

Figure 3 Relationship between precaecal digestible P concentration in broiler diets ( $\mathrm{pcdP} ; \mathrm{g} / \mathrm{kg}$ ) (treatments means and standard deviation) and dietary $P$ content $(\mathrm{g} / \mathrm{kg}$ ) in experiment 2 , analysed with a linear regression model represented by the line. Goodness of fit of the model: $\mathrm{R}^{2}=0.972$ and $\mathrm{SE}=0.137$. Constant $=1.03 \pm 0.11$ and slope of the line $=$ $0.468 \pm 0.02$. 
The performance characteristics of experiment 2 are provided in Table 13.

Table 13 Performance characteristics of broilers in experiment 2 from day 14 until day 24 supplied with diets varying in retainable $\mathrm{P}$ ( $\mathrm{rP} ; \mathrm{g} / \mathrm{kg}$ product).

\begin{tabular}{|c|c|c|c|c|c|}
\hline & $\begin{array}{l}1.5 \mathrm{rP} \\
\text { (basal) }\end{array}$ & $3.0 \mathrm{rP}$ & $4.5 \mathrm{rP}$ & SEM & P-value \\
\hline BW day $14(\mathrm{~g})$ & 452 & 446 & 448 & 4.1 & 0.514 \\
\hline BW day 24 (g) & $1210^{\mathrm{b}}$ & $1340^{\mathrm{a}}$ & $1334^{\mathrm{a}}$ & 17.3 & $<0.001$ \\
\hline ADG $(g / d)$ & $68.9^{b}$ & $81.3^{a}$ & $80.6^{a}$ & 1.31 & $<0.001$ \\
\hline $\operatorname{ADFI}(g / d)$ & $97.0^{b}$ & $109.0^{a}$ & $106.8^{a}$ & 1.51 & $<0.001$ \\
\hline Feed: gain $(\mathrm{g} / \mathrm{g})$ & $1.409^{a}$ & $1.341^{b}$ & $1.326^{\mathrm{b}}$ & 0.0099 & $<0.001$ \\
\hline Mortality (\%) & 1.3 & 0.0 & 0.0 & 0.79 & 0.405 \\
\hline
\end{tabular}

BW at day 14 did not differ between treatments. Birds fed the basal diet had lower BW at d24 and consequently lower ADG $(P<0.001)$ compared to the 3.0 and $4.5 r P$ treatments. Birds fed the basal diet had lower FI levels and higher FCR over the period of day 14 to day 24 compared to the other treatments. Mortality levels did not differ among treatments. The pcdP and pcdCa digestibility values and the level of phytate degradation of the diets are shown in Table 14.

Table 14 Precaecal diet digestibility (\%) of $\mathrm{P}, \mathrm{Ca}$, and phytate degradation, and the contents of available $P$ and available $\mathrm{Ca}(\mathrm{g} / \mathrm{kg})$ in experiment 2 with diets varying in retainable $P$.

\begin{tabular}{|c|c|c|c|c|c|}
\hline & $\begin{array}{c}1.5 \mathrm{rP} \\
\text { (basal) }\end{array}$ & $3.0 \mathrm{rP}$ & $4.5 \mathrm{rP}$ & SEM & P-value \\
\hline$P$ & $81.7^{\mathrm{a}}$ & $63.8^{\mathrm{b}}$ & $62.0^{\mathrm{b}}$ & 0.77 & $<0.001$ \\
\hline $\mathrm{Ca}$ & $70.1^{\mathrm{a}}$ & $47.1^{b}$ & $40.9^{c}$ & 1.40 & $<0.001$ \\
\hline Phytate & $96.9^{a}$ & $82.6^{b}$ & $68.2^{c}$ & 2.48 & $<0.001$ \\
\hline Available P content & $2.6^{c}$ & $3.4^{\mathrm{b}}$ & $4.5^{a}$ & 0.05 & $<0.001$ \\
\hline Available Ca content & $3.1^{\mathrm{b}}$ & $3.2^{\mathrm{b}}$ & $3.8^{\mathrm{a}}$ & 0.13 & $<0.001$ \\
\hline
\end{tabular}

Increasing the level of MCP in the phytate rich diet decreased P digestibility from 81.7 via 63.8 to $62.0 \%$ for the $1.5,3.0$ and 4.5 aP diets, respectively, and as a consequence, the dietary aP content increased from 2.6 via 3.3 to $4.5 \mathrm{~g} / \mathrm{kg}$. Ca digestibility decreased with increasing MCP levels from $70.1 \%$ in the basal diet to $40.9 \%$ in the $4.5 \mathrm{rP}$ diet. In the basal diet, the level of phytate degradation was high (96.9\%), but the level substantially reduced to $68.2 \%$ in the $4.5 \mathrm{rP}$ diet. Dietary aP contents linearly increased with increasing rP contents from 2.6 to $4.5 \mathrm{~g} / \mathrm{kg}$. The aCa content of the 1.5 and 3.0 $\mathrm{rP}$ diets were reduced (3.1-3.2 g/ $\mathrm{kg}$ ) compared to the aCa content of $4.5 \mathrm{rP}$ diet $(3.8 \mathrm{~g} / \mathrm{kg})$.

\subsection{Experiment 3: effect of PP supplementation to a PP- rich basal diet}

\subsubsection{Results of the Wageningen Study}

Figure 4, which provided both the broken stick and linear relationship between pcdP content $(\mathrm{g} / \mathrm{kg})$ and dietary $P(\mathrm{~g} / \mathrm{kg})$ as analysed for the results in experiment 3 , shows that $90 \%$ of variation in pcdP content could be explained by the broken stick model. The pcdP digestibility of SBM, reflected by the slope, was estimated to be $69.3 \pm 7.22 \%$ before the break point value at a dietary $P$ level of $4.12 \pm 0.094 \mathrm{~g} / \mathrm{kg}$, and $0 \%$ after this break point value. Figure 4 also shows that $78 \%$ of variation in pcdP content could be explained by the linear regression model. The pcdP digestibility of SBM, reflected by the slope, over the whole test range was estimated to be $42.4 \pm 5.4 \%$. 


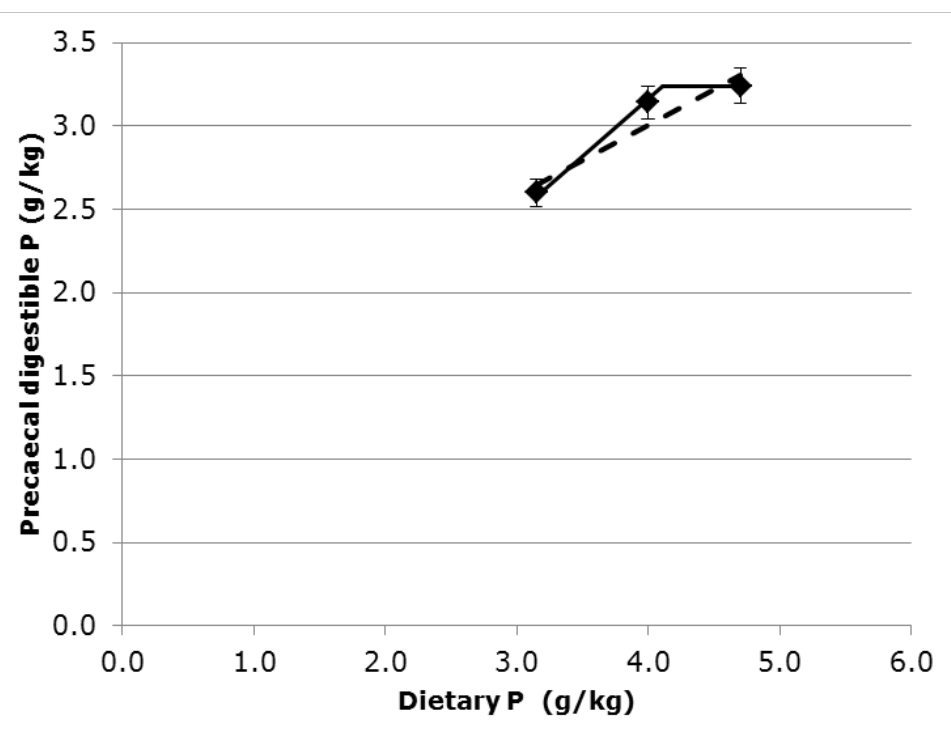

Figure 4 Relationship between precaecal digestible $\mathrm{P}$ concentration in broiler diets of experiment 3 ( $\mathrm{pcdP} ; \mathrm{g} / \mathrm{kg}$ ) (treatments means and standard deviation) and dietary P content ( $\mathrm{g} / \mathrm{kg}$ ) analysed with a broken stick regression and a linear regression model, represented by the solid and dashed lines, respectively. Goodness of fit of the broken stick model: $\mathrm{R}^{2}=$ 0.896 and $\mathrm{SE}=0.103$. Parameter estimates: break point value of precaecal digestible $\mathrm{P}$ $=3.24 \pm 0.042 \mathrm{~g} / \mathrm{kg}$ and dietary $\mathrm{P}=4.12 \pm 0.094 \mathrm{~g} / \mathrm{kg}$, slope before break point $=$ $0.693 \pm 0.072$, slope after break point $=0$. Goodness of fit of the linear regression model: $\mathrm{R}^{2}=0.779$ and $\mathrm{SE}=0.15$. Parameter estimates: constant $=1.31 \pm 0.22$, slope $=$ $0.424 \pm 0.054$.

The performance characteristics of experiment 3 are provided in Table 15.

Table 15 Performance characteristics of broilers in experiment 3 from day 14 until day 24 supplied with diets varying in retainable $\mathrm{P}$ ( $\mathrm{rP} ; \mathrm{g} / \mathrm{kg}$ product).

\begin{tabular}{|c|c|c|c|c|c|}
\hline & $\begin{array}{l}1.5 \mathrm{rP} \\
\text { (basal) }\end{array}$ & $1.8 \mathrm{rP}$ & $2.1 \mathrm{rP}$ & SEM & P-value \\
\hline BW day 14 (g) & 452 & 451 & 454 & 3.20 & 0.835 \\
\hline BW day 24 (g) & 1210 & 1265 & 1237 & 23.2 & 0.095 \\
\hline $\operatorname{ADG}(g / d)$ & $68.9^{\mathrm{b}}$ & $73.9^{a}$ & $71.2^{\mathrm{ab}}$ & 1.31 & 0.046 \\
\hline ADFI $(g / d)$ & 97.0 & 96.7 & 95.8 & 1.66 & 0.869 \\
\hline Feed: gain $(\mathrm{g} / \mathrm{g})$ & $1.409^{a}$ & $1.308^{b}$ & $1.347^{b}$ & 0.0153 & 0.001 \\
\hline Mortality (\%) & 1.3 & 0.0 & 2.7 & 1.30 & 0.367 \\
\hline
\end{tabular}

BW at day 14, Feed intake and mortality did not differ between treatments, whereas BW at day 24 tended to differ $(P=0.095)$. Birds fed the basal diet had a lower ADG $(P=0.046)$ compared to the 1.8 treatment, whereas the $2.1 \mathrm{rP}$ treatment was in between. Birds fed the basal diet had a higher feed:gain ratio compared to the two other treatments. The pcdP and pcdCa digestibility values and the level of phytate degradation of the diets are shown in Table 16. 
Table 16 Precaecal diet digestibility (\%) of $\mathrm{P}, \mathrm{Ca}$, and phytate degradation, and the contents of available $\mathrm{P}$ and available $\mathrm{Ca}(\mathrm{g} / \mathrm{kg})$ in experiment 3 with diets varying in retainable $\mathrm{P}$.

\begin{tabular}{|c|c|c|c|c|c|}
\hline & $\begin{array}{c}1.5 \mathrm{rP} \\
\text { (basal) }\end{array}$ & $1.8 \mathrm{rP}$ & $2.1 \mathrm{rP}$ & SEM & P-value \\
\hline $\mathrm{P}$ & $81.7^{\mathrm{a}}$ & $79.2^{\mathrm{a}}$ & $68.4^{\mathrm{b}}$ & 0.94 & $<0.001$ \\
\hline $\mathrm{Ca}$ & $70.1^{\mathrm{a}}$ & $66.6^{a}$ & $55.7^{\mathrm{b}}$ & 1.40 & $<0.001$ \\
\hline Phytate & $96.9^{a}$ & $96.2^{\mathrm{a}}$ & $91.3^{b}$ & 0.85 & 0.002 \\
\hline Available P content & $2.6^{\mathrm{b}}$ & $3.1^{\mathrm{a}}$ & $3.2^{\mathrm{a}}$ & 0.06 & $<0.001$ \\
\hline Available Ca content & $3.1^{\mathrm{b}}$ & $3.5^{\mathrm{a}}$ & $3.6^{\mathrm{a}}$ & 0.11 & $<0.001$ \\
\hline
\end{tabular}

Broilers fed the $2.1 \mathrm{rP}$ diet showed a lower $\mathrm{P}$, and Ca digestibility, and a lower level of phytate degradation compared to broilers fed the 1.5 and 1.8 aP diets. The determined dietary aP contents amounted $2.6,3.1$ and $3.2 \mathrm{~g} / \mathrm{kg}$ for the $1.5,1.8$ and $2.1 \mathrm{rP}$ diets, respectively. Dietary aP content of the $1.5 \mathrm{rP}$ diet $(2.6 \mathrm{~g} / \mathrm{kg})$ was lower compared to the 1.8 and $2.1 \mathrm{rP}$ diet $(3.1-3.2 \mathrm{~g} / \mathrm{kg})$. Dietary aCa content of the $1.5 \mathrm{rP}$ diet $(3.1 \mathrm{~g} / \mathrm{kg})$ was lower compared to the 1.8 and $2.1 \mathrm{rP}$ diet $(3.5-3.6 \mathrm{~g} / \mathrm{kg})$.

\subsubsection{Results of the study of Schothorst Feed Research}

Figure 5 provides both the linear relationship between pcdP content ( $g / k g ~ D M)$ and dietary $P(g / k g$ $D M)$ as well as between the faecal digestible $P$ content ( $g / k g D M)$ and dietary $P(g / k g ~ D M)$, analysed for the results of Schothorst Feed Research (SFR) in experiment 3. It shows that $97.5 \%$ of variation in pcdP content and $99.9 \%$ of variation in faecal digestible $\mathrm{P}$ content could be explained by the linear models. The pcdP digestibility of SBM, reflected by the slope, was estimated to be $40.7 \pm 3.1 \%$, whereas the faecal $P$ digestibility was estimated to be $36.1 \pm 3.1 \%$.

Ileal

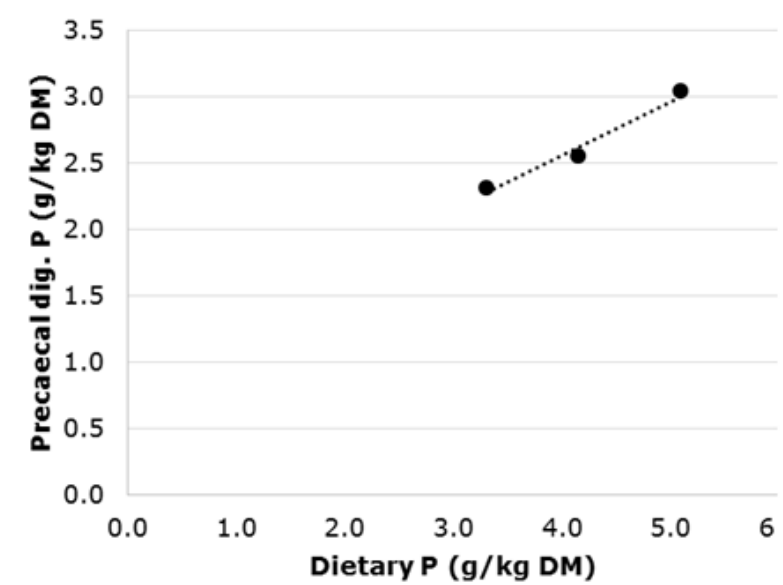

Faecal

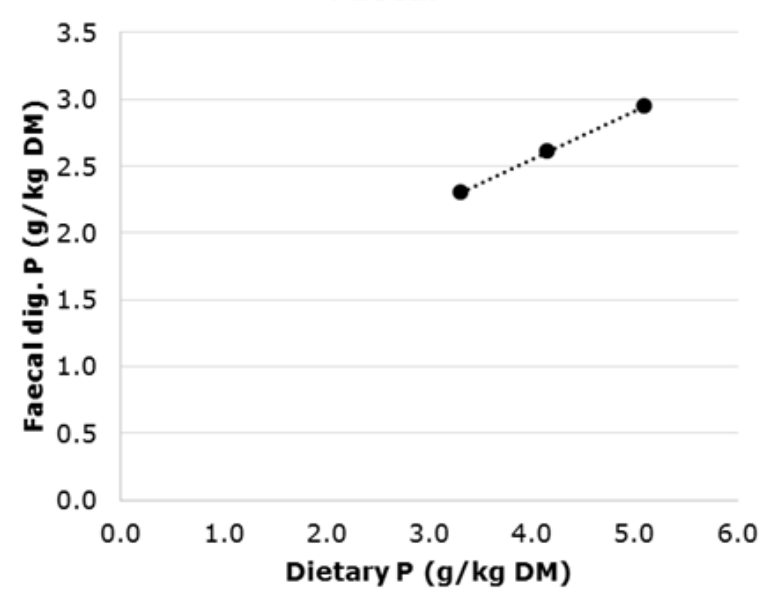

Figure 5 Left panel: relationship between precaecal digestible $\mathrm{P}$ concentration in broiler diets ( $\mathrm{pcdP} ; \mathrm{g} / \mathrm{kg}$ ) and dietary $\mathrm{P}$ content $(\mathrm{g} / \mathrm{kg})$ in experiment 3 conducted at SFR, analysed with a linear regression model represented by the line. Goodness of fit of the model: $R^{2}=$ 0.975 , constant $=0.93$ and slope of the line $=0.407 \pm 0.031$. Right panel: relationship between faecal digestible $P$ concentration in broiler diets ( $\mathrm{pcdP} ; \mathrm{g} / \mathrm{kg}$ ) and dietary $\mathrm{P}$ content $(\mathrm{g} / \mathrm{kg})$ in experiment 3 , analysed with a linear regression model represented by the line. Goodness of fit of the model: $R^{2}=0.999$, constant $=1.11$ and slope of the line $=0.361 \pm 0.031$.

The performance characteristics are provided in Table 17. 
Table 17 Performance characteristics of broilers in experiment 3 conducted at SFR from day 20 until day 27 supplied with diets varying in retainable $\mathrm{P}$ ( $\mathrm{rP} ; \mathrm{g} / \mathrm{kg}$ product).

\begin{tabular}{|c|c|c|c|c|c|}
\hline & $\begin{array}{l}1.5 \mathrm{rP} \\
\text { (basal) }\end{array}$ & $1.8 \mathrm{rP}$ & $2.1 \mathrm{rP}$ & LSD & P-value \\
\hline BW day 20 (g) & 883 & 882 & 884 & 9.0 & 0.89 \\
\hline BW day $27(\mathrm{~g})$ & 1554 & 1594 & 1574 & 45.0 & 0.19 \\
\hline BWG d20-27 (g) & 671 & 712 & 691 & 45.0 & 0.18 \\
\hline $\mathrm{FI} d 20-\mathrm{d} 27(\mathrm{~g})$ & $949^{b}$ & $920^{a}$ & $909^{a}$ & 28.0 & 0.03 \\
\hline Feed: gain $(\mathrm{g} / \mathrm{g})$ & $1.418^{\mathrm{b}}$ & $1.292^{\mathrm{a}}$ & $1.325^{a}$ & 0.074 & 0.01 \\
\hline
\end{tabular}

BW at day 20 and day 27, and BWG over this period were not affected by dietary treatments. Birds fed the basal diet had a lower FI $(P=0.03)$ compared to the 1.8 and $2.1 \mathrm{rP}$ treatment. Birds fed the basal diet had a higher feed: gain ratio compared to the two other treatments. In treatment 2, 2 birds died in one cage ( $16.7 \%$ mortality), resulting for the whole study in $0.9 \%$ mortality. This cage was removed as outlier for technical data. No mortality occurred in the remaining pens.

The pcdP and faecal digestible P digestibility values and the level of phytate degradation of the diets are shown in Table 18.

Table 18 Precaecal and faecal diet digestibility (\%) of P in experiment 3, conducted at SFR.

\begin{tabular}{|c|c|c|c|c|c|}
\hline & $\begin{array}{l}1.5 \mathrm{rP} \\
\text { (basal) }\end{array}$ & $1.8 \mathrm{rP}$ & $2.1 \mathrm{rP}$ & LSD & P-value \\
\hline Precaecal & $69.7^{b}$ & $61.4^{\mathrm{a}}$ & $59.5^{a}$ & 2.98 & $<0.001$ \\
\hline Faecal & $69.5^{c}$ & $62.8^{b}$ & $57.8^{a}$ & 2.45 & $<0.001$ \\
\hline
\end{tabular}

Broilers fed the basal diet had higher precaecal and faecal $\mathrm{P}$ digestibility coefficients compared to the 1.8 and $2.1 \mathrm{rP}$ treatments. Faecal P digestibility of the diet linearly decreased with increasing rP content.

\subsection{Experiment 4: effect of added dietary structure to a PP-rich basal diet}

Table 19 provides the precaecal diet digestibility (\%) of $\mathrm{P}$, and $\mathrm{Ca}$, the level of phytate degradation $(\%)$, and the dietary aP content of the two diets in experiment 4.

Table 19 Precaecal diet digestibility (\%) of $\mathrm{P}, \mathrm{Ca}$, and phytate degradation (\%), and the contents of available $P$ and available $\mathrm{Ca}(\mathrm{g} / \mathrm{kg})$ in experiment 4 with diets varying in dietary structure.

\begin{tabular}{lcccc} 
& 1.5 rP (basal) & $\begin{array}{c}1.5 \text { rP } \\
\text { (structure) }\end{array}$ & SEM & P-value \\
$\mathrm{P}$ & 81.9 & 83.6 & 1.24 & 0.380 \\
\hline $\mathrm{Ca}$ & $70.1^{\mathrm{a}}$ & $80.3^{\mathrm{b}}$ & 1.40 & 0.003 \\
\hline Phytate & 96.9 & 95.5 & 0.53 & 0.117 \\
\hline Available P content & 2.6 & 2.6 & 0.05 & 0.401 \\
\hline Available Ca content & 3.1 & 3.4 & 0.07 & $<0.001$ \\
\hline
\end{tabular}

Supplementation of phytate P-rich diets with coarse oat hulls did not affect the PcdP-\% and dietary aP content, and the level of phytate degradation. Precaecal Ca digestibility, however, increased by oat hulls supplementation, resulting in an $0.3 \mathrm{~g} / \mathrm{kg}$ increase in aCa content.

The performance characteristics of experiment 4 are provided in Table 20. 
Table 20 Performance characteristics of broilers in experiment 4 from day 14 until day 24 supplied with diets varying in dietary structure.

\begin{tabular}{|c|c|c|c|c|}
\hline & $\begin{array}{l}1.5 \mathrm{rP} \\
\text { (basal) }\end{array}$ & $\begin{array}{l}1.5 \mathrm{rP} \\
\text { (structure) }\end{array}$ & SEM & P-value \\
\hline BW day $14(\mathrm{~g})$ & 452 & 451 & 3.41 & 0.745 \\
\hline BW day 24 (g) & 1210 & 1241 & 16.4 & 0.211 \\
\hline ADG $(g / d)$ & 68.9 & 71.9 & 1.25 & 0.128 \\
\hline $\operatorname{ADFI}(g / d)$ & 97.0 & 101.1 & 2.24 & 0.232 \\
\hline Feed: gain $(\mathrm{g} / \mathrm{g})$ & 1.409 & 1.406 & 0.016 & 0.907 \\
\hline Mortality (\%) & 1.3 & 3.0 & 2.6 & 0.594 \\
\hline
\end{tabular}

The oat hull supplementation did not affected any of the determined performance parameters. 


\section{Discussion}

\subsection{Precaecal P digestibility in phytate-low diets}

Experiment 1 was conducted to estimate in phytate-low diets the dietary (precaecal digestible) $\mathrm{P}$ content above which a decrease in precaecal $\mathrm{P}$ digestibility is to be taken into account. From the published literature this was not clear since Rodehutscord et al. (2012) observed over the whole test range a linear increase in pcdP with increasing dietary $\mathrm{P}$ content. Results of experiment 1 showed that precaecal absorption of $\mathrm{P}$ declined above a certain level of $\mathrm{P}$ intake and absorption. The broken line model indicated that this decline started at a pcdP level of $4.8 \pm 0.17 \mathrm{~g} / \mathrm{kg}$ feed. Rodehutscord et al. (2012) determined the pcdP of MCP $(\mathrm{g} / \mathrm{kg})$ in an experiment with 5 incremental levels of dietary $P$, ranging from $2.39-8.14 \mathrm{~g} / \mathrm{kg}$, by adding MCP to a basal ration. The range in determined pcdP was $0.94-3.0 \mathrm{~g} / \mathrm{kg}$. For this range, a linear relationship between pcdP and dietary $P(\mathrm{~g} / \mathrm{kg})$ was observed, i.e. no break point could be established. In contrast to the pcdP response, over the tested dietary $P$ range a break point was established in the response of faecal digestible $P$. This indicates that excretion of excess $P$ in the urine progressively increased at a lower level of dietary $P$ as compared to the dietary $\mathrm{P}$ level at which precaecal absorption of dietary $\mathrm{P}$ started to decline. In the study of Rodehutscord et al. (2012) a progressive increase in excretion of $\mathrm{P}$ was observed above a dietary $\mathrm{P}$ level of $5.2 \mathrm{~g} / \mathrm{kg}$, corresponding with a pcdP level of $2.46 \mathrm{~g} / \mathrm{kg}$ and an apparent total tract retention (ATTR) P level of $2.71 \mathrm{~g} / \mathrm{kg}$. This ATTR P level of $2.71 \mathrm{~g} / \mathrm{kg}$ agreed well with the break point value of ATTR of $P$ of $2.4 \mathrm{~g} / \mathrm{kg}$ observed in a study from Leske and Coon (2002). The results from Rodehutscord et al. (2012) and Leske and Coon (2002) combined with the results of experiment 1 in the present study indicate that a decline in ATTR may be observed at a lower $\mathrm{P}$ intake than a decline in precaecal digestibility, presumably due to a progressive increase in $\mathrm{P}$ excretion in the urine. The precaecal digestibility of $P$ seems reliable below a pcdP level of at least $3.7 \mathrm{~g} / \mathrm{kg}$ feed, and probably even below $4.8 \mathrm{~g} / \mathrm{kg}$, because in the present study in experiment 1 the model estimated a relation linear up to $4.8 \mathrm{~g} \mathrm{pcdP} / \mathrm{kg}$. The range in observed pcdP levels in experiment 1 was sufficiently large to estimate a break point value. However, because of the limited number of pcdP levels created in experiment 1 it remains unknown whether or not there truly is a distinct break point value. The determined pcdP digestibility of MCP of $88.0 \%$ in the current study agrees well with the ATTR of P values from CVB (2011) for monohydrate MCP of $85 \%$. Based on the results of experiment 1 it can be recommended to use low phytate diets for determining pcdP-\% of feed phosphates. Under this condition, the dietary total P content is not very critical, because the pcdP-\% was constant over a large dietary total $P$ range $(2.0$ to $5.8 \mathrm{~g} / \mathrm{kg})$.

\subsection{Phytate degradation}

Results of experiment 2 and 3 (Wageningen study) showed that the level of phytate degradation was very high $(91-97 \%$ ) in low aP-diets with a determined aP content of maximal $3.2 \mathrm{~g} / \mathrm{kg}$, whereas phytate degraded substantially less in diets with a higher aP content. In these experiments, SBM was the only phytate source, indicating actually that we are considering the level of phytate degradation in SBM. Van der Klis and Blok (1997) determined in broilers under conditions of low dietary rP $(1.8 \mathrm{~g} / \mathrm{kg})$ and $\mathrm{Ca}(5.0 \mathrm{~g} / \mathrm{kg})$ that $50-69 \%$ of phytate in SBM was degraded. More recently, Zeller et al. (2015a) reported that $74 \%$ of phytate $\left(\mathrm{InSP}_{6}\right)$ was degraded at the end of the ileum of broilers fed a corn soybean meal based diet. Only in case of a very high level of dietary phytase supplementation $(12,500$ FTU $/ \mathrm{kg}$ ) phytate degradation levels above 90\% were reported (Zeller et al., 2015b). The mentioned values are still lower compared to the values observed in the current study. It can be questioned whether such high values of phytate degradation are actually possible? Or might the applied method of phytate analysis overestimate the level of phytate degradation?

To answer these questions, the level of phytate degradation, that theoretically should be degraded to realize the measured dietary pcdP-content, was calculated. For this, the by Van der Klis and Blok (1997) proposed equation [eq. 5: \%dIPP $=\{[(\mathrm{DPp} / 0.80)-\mathrm{nIPPf}] / \mathrm{IPP}\} * 100]$ was used. In this equation, a determining assumption is that the efficacy of pcdP absorption amounts $80 \%$, which is the pcdP-\% of MCP measured under conditions of low dietary $\mathrm{Ca}$ and P contents. The calculated levels of phytate degradation in low aP diets agrees very well with the measured levels. This supports the observed findings of the spectrophotometrically measured levels of phytate degradation. 
As mentioned above, the efficacy factor for pcdP absorption has a large impact on the outcome of the equation. At the lowest dietary $\mathrm{rP}$ levels of experiment 2 and 3, the efficacy factor for pcdP absorption should even be 0.83 instead of 0.80 to have a full match between the calculated and measured level of phytate degradation. By using the equation for the higher dietary rP levels of experiment 2 and 3 , the calculated level of phytate degradation did not agree with the observed level. It can be expected that the efficacy factor for pcdP absorption at these rP levels would be lower than 0.8. For a full match between the calculated and observed values, this factor should be set at 0.67 and 0.71 for experiment 2 and 3 , respectively.

In experiment 3 conducted by SFR, phytate degradation was not measured. Based on the equation mentioned above, the calculated level of phytate degradation amounted 77 and $61 \%$ for the 1.5 and $1.8 \mathrm{rP}$ diets, respectively. This is substantially lower than the value of $96 \%$ in experiment 3 , conducted by Wageningen. In the SFR study, the measured pcdP-contents of the 1.5 and $1.8 \mathrm{rP}$ diets were 0.6 and $1.0 \mathrm{~g} / \mathrm{kg}$ lower, respectively compared to the values of the Wageningen study, apparently because of the lower levels of phytate degradation. In both studies, the same animal strain, diets and precaecal $\mathrm{P}$ digestibility protocol were used. Despite this, determined dietary pcdP contents substantially differed among studies, which might be related to differences in the activities of intestinal brush border phytase (Maenz and Classen, 1998; Applegate et al., 2003) or the presence of phytate degrading microbiota strains in the GIT (Raghavendra and Halami, 2009).

Van Krimpen et al. (2016) determined the level of phytate degradation in wheat-SBM based broiler diets at 21 and 38 days of age. Diets varied in rP content, because of incremental MCP dosages to a low-rP basal diet. Ca:aP ratio's in these diets were fixed at a level of 2.2. As shown in Figure 6, phytate degradation ranged from 13 to $45 \%$. In that study, the levels of phytate degradation are substantially lower compared to the levels measured in the current study. This might be partly explained by the presence of wheat in the diet, which phytate degradability varied according to Van der Klis and Blok (1997) between 36 and 45\%.

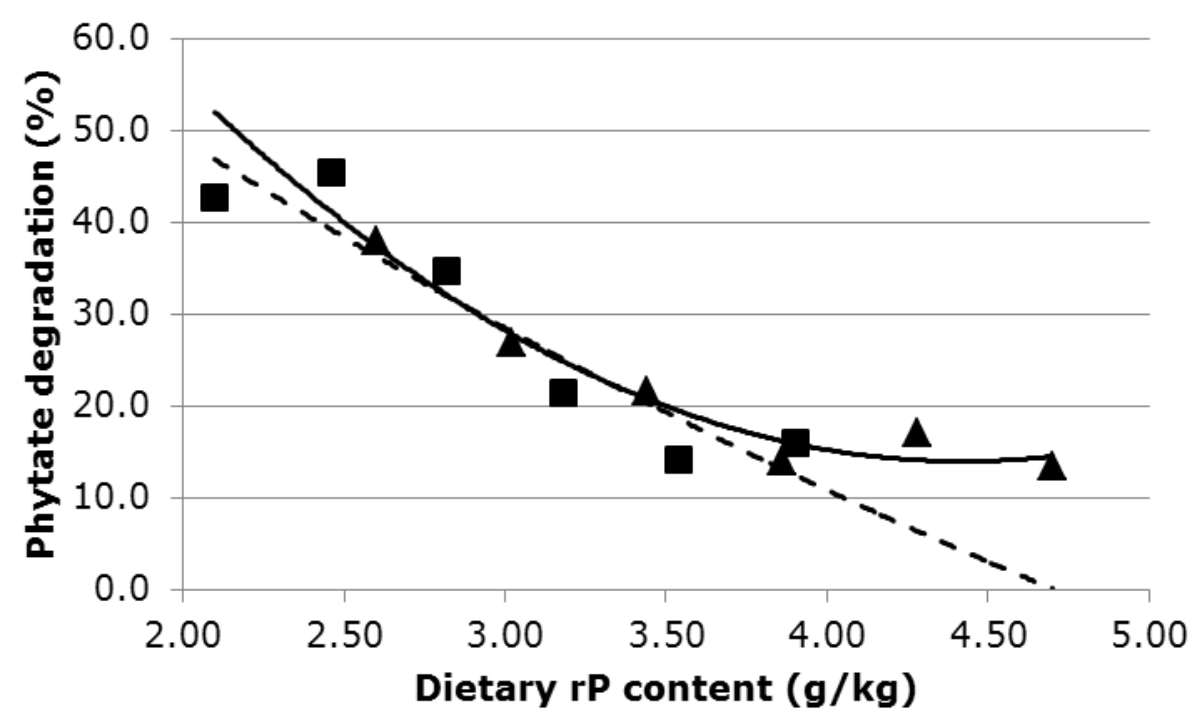

Figure 6 Relationship between dietary $\mathrm{rP}$ content $(\mathrm{g} / \mathrm{kg})$ and level of phytate degradation in broilers of 21 (triangels) and 38 (squares) days of age (Van Krimpen et al., 2016)

After combining the results of experiment 2, 3 and 4, it was observed that phytate degradation was highly dependent on the dietary nPP-content (Figure 7). Based on this relationship, it can be concluded that the level of phytate degradation in broilers inversely decreased with increasing amounts of easily available non-phytate $P$ in the diet. It is suggested that inorganic $P$ reduces the activity of added phytases or phytases from the microbiota or mucosa (Zeller et al., 2015b). These authors reported that phytase activity, however, was not reduced if a very high phytase level $(12,500$ FTU/ kg) was supplemented to the diet, resulting in an increased level of net absorbed P, compared to unsupplemented diets or diets supplemented with standard levels of added phytase.

This mechanism significantly affects the determination of the pcdP-\% of an ingredient in phytate-rich diets. This was the case in experiment 3. In this experiment, the supplementation of aP from MCP coincided with a decrease in phytate degradation, overall resulting in a low pdcP-\% of $46.8 \%$, whereas the pcdP-\% of the same MCP source in experiment 1 amounted $88.0 \%$. Therefore, it is recommended to use low nPP diets for testing the pcdP-\% of phytate-rich ingredients. 


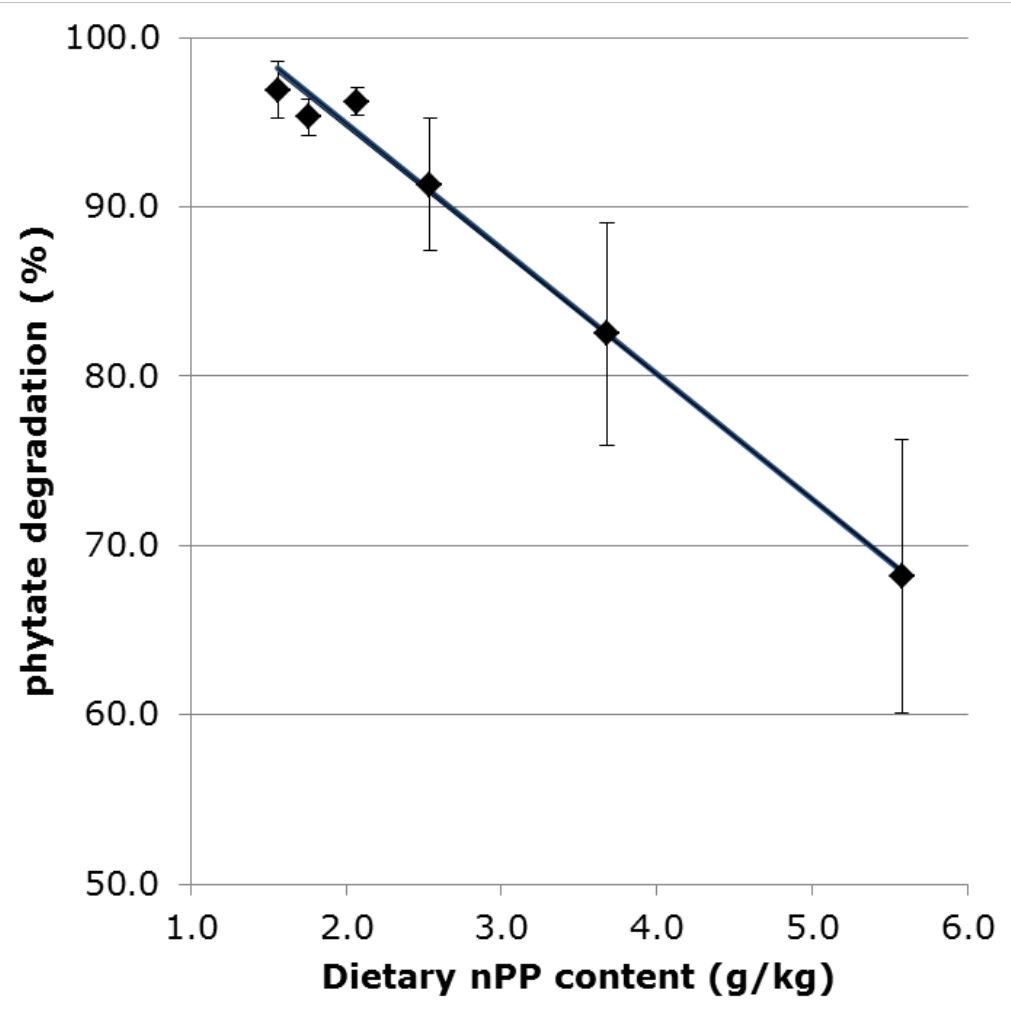

Figure 7 Relationship between non-phytate P concentration in broiler diets of experiment 2 and 3 $(\mathrm{g} / \mathrm{kg})$ (treatments means and standard deviation) and level of phytate degradation $(\mathrm{g} / \mathrm{kg})$ analysed with a linear regression model. Goodness of fit of the linear regression model: $\mathrm{R}^{2}=0.843$ and $\mathrm{SE}=0.045$. Parameter estimates: constant $=109.71 \pm 1.72$, slope $=-7.39 \pm 0.537$.

\subsection{Precaecal versus faecal P digestibility}

Based on the SFR study, the pcdP-\% of SBM amounted $40.7 \%$, which was in line with the pcdP-\% of $42.4 \%$, determined in the Wageningen study. The faecal P digestibility- $\%$ of SBM in the SFR study amounted $36.1 \%$, which was numerical but not significantly lower compared to the pdcP-\%. The Pdigestibility coefficient according to CVB (2011) is 41.5\%. Based on the results of this study, it can be concluded that the pcdP-\% of SBM determined according to the WPSA protocol does not differ from the faecal $P$ digestibility according to the CVB protocol. It should be kept in mind that for this faecal $P$ digestibility method the dietary $\mathrm{rP}$ contents should not be above bird's requirement level to prevent $\mathrm{P}$ excretion via urine.

\subsection{Effect of dietary structure on phytate degradation}

In the current study, precaecal Ca digestibility was increased by $5 \%$ oat hulls supplementation. This finding was in line with the studies of J iménez-Moreno et al. (2009) and González-Alvarado et al. (2010). Contrary to our hypothesis, it was not confirmed in the current study that dietary structure the levels of phytate degradation and precaecal P digestibility further improved. The current findings were partly in line to those of Kilburn and Edwards (2004), who observed that feeding coarse maize diet to broilers did not increase the level of $\mathrm{P}$ retention, but that the coarse maize diet improved phytate $\mathrm{P}$ retention and plasma $\mathrm{P}$ levels. In the current study, values for $\mathrm{P}$ digestibility $(82.8 \%)$ and phytate degradation (96.2\%) were already very high, which gave not many space for further improvement. The level of phytate degradation in the study of Kilburn and Edwards (2004) increased from $28.0 \%$ (fine) to $32.8 \%$ (coarse), but the latter value was still far below the findings in the current study. 


\section{Conclusions}

Based on findings of the present experiment, the following conclusions can be drawn:

- $\quad$ Literature shows that the dietary Ca, P, and Vitamin D content, the Ca: aP ratio and dietary structure affects phytate degradation in broilers.

- In phytate-low broiler diets, pcdP-\% was constant over a large aP-range.

- $\quad$ Phytate degradation showed a large variation among studies. Phytate degradation linearly decreased with increasing dietary non-phytate phosphorus content.

- $\quad$ The pcdP-\% of SBM determined according to the WPSA protocol does not differ from the faecal P digestibility according to the CVB protocol.

- Dietary structure did not affect phytate degradation and pdcP-\% of the diet, but increased precaecal Ca digestibility.

\section{Recommendations}

It can be recommended to use phytate-low diets for determining pcdP-\% of feed phosphates. Under this condition, the dietary total $\mathrm{P}$ content is not very critical, because the pcdP-\% was constant over a large dietary total $P$ range ( 2.0 to $5.8 \mathrm{~g} / \mathrm{kg}$ according to a broken-stick model). It is recommended to use low nPP diets for testing the pcdP-\% of phytate-rich ingredients. 


\section{References}

Alaeldein, M. Abudabos. 2012. Intestinal phytase activity in chickens. African Journal of Microbiology Research 6:4932-4938.

Al-Mastri, M.R. 1995. Absorption and endogenous excretion of phosphorus in growing broiler chicks, as influenced by calcium and phosphorus ratios in feed. British Journal of Nutrition 74:407-415.

Amerah, A.M., Plumstead, P.W., Barnard, L.P., and Kumar, A. 2014. Effect of calcium level and phytase addition on ileal phytate degradation and amino acid digestibility of broilers fed corn-based diets. Poultry Science 93:906-15.

Anderson, P.A. 1985. Interactions between proteins and constiuents that affect protein quality. Pages 31-45 in: Finley, G.W., and Hopkins, D.T. (eds.). Digestibility and Amino Acid Availability in Cereals and Oilseeds. American Association of cereal Chemists, St. Paul, MN.

Applegate, T.J., Angel, R., and Classen, H.L. 2003. Effect of dietary calcium, 25hydroxycholecalciferol, or bird strain on small intestinal phytase activity in broiler chickens. Poultry Science 82: 1140-1148.

Applegate, T.J., and Angel, R. 2004. Phytase: Basics of enzyme function, Purdue University Department of Animal Sciences. AS-560-W.

Ashton, W.M., Evans, C., and Williams, P.C. 1960. Phosphorus compounds of oats. II. The utilization of phytate phosphorus by growing chicks. Journal of the Science of Food and Agriculture 11:722-727.

Ballam, G.C., Nelson, T.S., and Kirby, L.K. 1985. Effect of different dietary levels of calcium and phosphorus on phytase hydrolysis by chicks. Nutrition Reports International 32:909-913.

Bloem, M.W., Moench-Pfanner, R., and Kiess, L. 2001. Combating micronutrient deficiencies - An important component of poverty reduction. Biomedical and Environment Sciences 14:92-97.

Bos, K.D., Verbeek, C., Van Eeden, C.H.P., Slump, P., and Wolters, M.G.E. 1991. Improved determination of phytate by iom-exchange chromatography. Journal of Agricultural and Food Chemistry 39: 1770-1772.

Brinch-Pedersen, H., Sørensen, L.D., and Holm, P.B. 2002. Engineering crop plants: getting a handle on phosphate. Trends in Plant Science 7:118-125.

Broz, J. 1993. Enzymes as feed additives in poultry nutrition - Current applications and future trends. Monatshefte fur Veterinarmedizin 48: 213-217.

Centeno, C., Arija, I, Viveros, A., and Brenes, A. 2007. Effects of citric acid and microbial phytase on amino acid digestibility in broiler chickens. British Poultry Science 48: 469-479.

Chen, R., Xue, G., Chen, P., Yao, B., Yang, W., Ma, Q., and Shi, J. 2008. Transgenic maize plants expressing a fungal phytase gene. Transgenic Research 17:633-643.

Common, R.H. 1940. The phytic acid content of some poultry feeding stuffs. Analyst 65:79-83.

Cordell, D., Drangert, J.O., and White, S. 2009. The story of phosphorus: Global food security and food for thought. Global Environmental Change 19:292-305.

Corring, T. 1980. Endogenous secretions in the pig. Pages 136-150 in: Current concepts of digestion and absorption in pigs. Low, A.G. and Partridge, I.G. (eds.). National Institute for Research in Dairying, Reading.

Cowieson, A.J., Acamovic, T., and Bedford, M.R. 2006. Phytic acid and phytase: Implications for protein utilization by poultry. Poultry Science $85: 878-885$.

CVB. 1997. Final system digestible phosphorus for poultry. Product Board of Animal Feed, documentation report no. 20.

CVB. 2011. CVB Table Booklet Feeding of Poultry.

CVB. 2012. Tabellenboek veevoeding 2012. CVB-reeks nr. 50, Productschap Diervoeder, Den Haag, Augustus 2012.

Daghir, N.J., and Farran, M.T. 1983. Phosphorus requirements of laying hens under different management conditions. Poultry Science 62: 1407.

Denbow, D.M., Grabau, E.A., Lacy, G.H., Kornegay, E.T., Russell, D.R., and Umbeck, P.F. 1998. Soybeans transformed with a fungal phytase gene improve phosphorus availability for broilers. Poultry Science 77:878-881.

Devegowda, G. 2005. Pages 1-3 in: Quality control of animal feeds. Reference Manual.

Diekmann, A. 2004. Beiträge zur optimierung der phosphorversorgung von wachsenden broilern. Doctoral thesis, Universität Halle-Wittenberg, Germany.

Driver, J.P., Pesti, G.M., Bakalli, R.I., and Edwards, H.M., Jr. 2006. The effect of feeding calcium and phosphorus deficient diets to broiler chickens during the starting and growing-finishing phases on carcass quality. Poultry Science 85: 1939-1946.

Driver, J.P., Pesti, G.M., Bakali, R.I., and Edwards, H.M., J r. 2005. Effects of nonphytate phosphorus concentrations on phytase efficacy in broiler chicks. Poultry Science 84: 1406-1417.

Dozier III, W.A., Macklin, K.S., Lee, M.D., Speegle, L., and Hess J.B. 2012. Evaluation of animal protein meals on nutritional quality and microbial profile of the gastrointestinal tract. Poultry Science Department. Auburn University. Auburn AL.

Dungelhoef, M., and Rodehutscord, M. 1995. Effects of phytases on the digestibility of Phosphorus in pigs. Übersichten zur Tierernährung 23: 133-157.

Edwards, H.M., Jr. 1982. Phosphorus. 1. Effect of breed and strain on utilization of suboptimal levels of phosphorus in the ration. Poultry Science 62:77-84. 
Edwards, H.M., Jr., and Veltman, J.R. 1983. Role of calcium and phosphorus in the aetiology of tibial dyschondroplasia in young chicks. Journal of Nutrition 113: 1568-1575.

Edwards, H.M., Jr., Palo, P., Soonchaerernying, S., and Elliot, M.A. 1989. Factors influencing the bioavailability of phytate phosphorus to chickens. In: Southgate, D., Johnson, I., and Fenwick, G.R. (eds.). Nutrient availability: chemical and biological aspects. The Royal Society of Chemistry Publ., Cambridge, UK.

Edwards, H.M., Jr. 1993. Dietary 1,25-dihydroxycholecalciferol supplementation increases natural phytate phosphorus utilization in chickens. Journal of Nutrition 123:567-577.

Eeckhout, W., and De Paepe, M. 1992. Betere benutting van de voeders. 1.1. Synthetische fytase. 1.1.2. Tarwefytase en een microbieel fytasepreparaat en de schijnbare fosforverteerbaarheid van een eenvoudig biggenvoeder. Lanbouwtijdschrift-Revue de l'Ágriculture, 45: 193-204.

Eeckhout, W., and De Paepe, M. 1994. Total phosphorus, phytate-phosphorus and phytase activity in plant feedstuffs. Animal Feed Science and Technology 47:19-29.

Ertl, D.S., Young, K.A., and Raboy, V. 1998. Plant genetic approaches to phosphorus management in agricultural production. Journal of Environmental Quality 27:299-304.

Esmaeilipoura, O., Van Krimpen, M.M., Jongbloed, A.W., De Jonge, L.H., and Bikker, P. 2013. The effects of temperature, moisture, duration of incubation time, calcium level, and soaking with water or citric acid on in vitro phytate degradation in a wheat-barley-rye-soybean meal-based diet. Animal Feed Science and Technology 183: 168-174.

FAO. 2003. Poultry keeping: a life-saver for poor rural households. Available at: www.fao.org/english/newsroom/news/2003/13201-en. html (accessed on 9 September 2008).

FAO. 2010. Smallholder Poultry production- livelihoods, food security and socio-cultural significance by Kryger NK, Thomsen AK, Whyte Ma and Dissing M, FAO Smallholder Poultry Production Paper. No. 4. Rome.

Fritz, J.C., Roberts, T., Bochne, J.W., and Hove, E.L. 1969. Factors affecting the chicks requirements for phosphorus. Poultry Science 48: 307-320.

Gillis, M.B., Norris, L.C., and Heuser, G.F. 1954. Studies on the biological value of inorganic phosphate. Journal of Nutrition 52:115-126.

Golovan, S.P., Meidinger, R.G., Ajakaiye, A., Cottrill, M., Wiederkehr, M.Z., Barney, D.J., Plante, C., Pollard, J.W., Fan, M.Z., Hayes, M.A., Laursen, J., Hjorth, J.P., Hacker, R.R., Phillips, J.P., and Forsberg, C.W. 2001. Pigs expressing salivary phytase produce low-phosphorus manure. National Biotechnology 19: 741-745.

González-Alvarado, J.M., J iménez-Moreno, E., González-Sánchez, D., Lázaro, R., and Mateos, G.G. 2010. Effect of inclusion of oat hulls and sugar beet pulp in the diet on productive performance and digestive traits of broilers from 1 to 42 days of age. Animal Feed Science and Technology 162:3746.

Goodband, R.D., Tokach, M.D., and Nelssen, J.L. 2002. The effects of diet particle size on animal performance. MF-2050 Feed Manufacturing, Department of Grain Science and Industry, Kansas State University.

Griffith, M. 1969. Influence of dietary particle size and composition on phosphorus availability. Poultry Science 48: 1255-1261.

Gross, M. 2010. Fears over phosphorus supplies. Current Biology 20:386-387.

Gunther, K.D., and Al-Masri, M.R. 1988. The influence of different phosphorus supply on phosphorus turnover in growing broilers by mean of 32P isotope. Journal of Animal Physiology and Animal Nutrition 59:132-142.

Gunther, F. 2005. A solution to the heap problem: the doubly balanced agriculture: integration with population. Available at http:// www.holon.se/folke/kurs/Distans/Ekofys/ Recirk/Eng/balanced.shtml. Accessed on 29 April 2009.

Harper, A.F., Kornegay, E.T., and Schell, T.C. 1997. Phytase supplementation of low-phosphorus growing-finishing pig diets improves performance, phosphorus digestibility, and bone mineralization and reduces phosphorus excretion. Journal of Animal Science 75:3174-3186.

Heloisa, H.D.C.M., Paulo, C.G., Horacio, S.R., Luiz, F.T.A., Tatiana, C.D.R., Rodrigo, L.D.A., and Arele, A.C. 2012. Dietary requirements of available phosphorus in growing broiler chickens at a constant calcium:available phosphorus ratio. Revista Brasileira de Zootecnia 41:2323-2328.

Hemati, H.R., Dashtbin, F., and Salari, J. 2013. Absorption and macro minerals interactions in broiler production. Global Veterinaria 11:49-54.

Hemme, A., Spark, M., Wolf, P., Paschertz, H., and Kamphues, J. 2005. Effects of different phosphorus sources in the diet on bone composition and stability (breaking strength) in broilers. Journal of Animal Physiology and Animal Nutrition 89: 129-133.

Hetland, H., and Svihus, B. 2001. Effect of oat hulls on performance, gut capacity and feed passage time in broiler chickens. British Poultry Science 42:354-361.

Hossain, M.A., Islam, A.F., and Iji, P.A. 2011. Performance of broiler chickens fed diets based on allvegetable ingredients. In: Proceedings of Recent Advances in Animal Nutrition in Australia 18:99 100.

Hu, H.L., Wise A., and Henderson, C. 1996. Hydrolysis of phytate and inositol tri-, tetra-, and pentaphosphates by the intestinal mucosa of the pig. Nutrition Research 16:781-787.

Huff, W.E., Moore, P.A., Waldroup, P.W., Waldroup, A.L., Balog, J.M., Huff, G.R., and Raboy, V. 1998. Effect of dietary phytase and high available phosphorus corn on broiler chicken performance. Poultry Science 77: 1899-1904.

Hurrell, R.F. 2004. Phytic acid degradation as a means of improving iron absorption. International Journal for Vitamin and Nutrition Research 74:445-452. 
Hurwitz, S., Dubrov, D., Elsner, U., Risenfeld, G., and Bar, A. 1978. Phosphate absorption and excretion in the young turkey as influenced by calcium intake. Journal of Nutrition 108: 1329-1335.

Huyghebaert G., Bleukx, W., Ruyseveldt, F., Delezie, E., and Maertens, L. 2009. Phosphorus supply and usage. In Proceedings 17th European Symposium on Poultry Nutrition. Edinburgh, Scotland.

ISO, I. 1999. 6496-Animal feeding stuffs-Determination of moisture and other volatile matter content. International Organisation for Standardisation, Geneva, Switzerland.

ISO, N. 1998. 11885-Water quality-determination of 33 elements by inductively coupled plasma atomic emission spectroscopy. International Organisation for Standardisation, AFNOR, Paris.

Iyayi, E.A., Fru-Nji, F., and Adeola, O. 2013. True phosphorus digestibility of black-eyed pea and peanut flour without or with phytase supplementation in broiler chickens. Poultry Science 92: 15951603.

Jacob, J.P. Wilson, H.R. Miles, R.D. Butcher, G. D., and Mather, F.B. 2003. Factors affecting egg production in backyard chicken flocks. Institute of Food and Agricultural Sciences, University of Florida. Fact Sheet PS-35. Available at http://edis.ifas.ufl.edu/PS029

Janssen, W.M.M.A., and Carré, B. 1985. Influence of fibre on digestibility of poultry feeds. Pages $71-$ 88 in: Recent Advances in Animal Nutrition. Haresing, W., and Cole, D.J.A. (eds.). Butterworths, London, UK.

J iménez-Moreno, E., González-Alvarado, J.M., González-Serrano, A., Lázaro, R., and Mateos, G.G. 2009. Effect of dietary fiber and fat on performance and digestive traits of broilers from one to twenty-one days of age. Poultry Science 88:2562-2574.

Jimenez-Moreno, E., Angel, C.R., Kim, S.W., Proszkowiec-Weglarz, M., and Ward, N.E. 2013. Dietary calcium and non-phytate phosphorus requirements of broilers chickens in the pre-starter phase. Available online at: www.wpsa.com/proceedings/ESPN_2013/assets/pdf/0100.pdf. Accessed on 15 May, 2014.

J ones, F.T. 1989. Feed ingredients quality. Pages 1-6 in: Proceedings of the Texas gulf Nutritional Symposium, Raleigh, NC.

Kerr, M.J., Classen, H.L., and Newkirk, R.W. 2000. The effects of gastrointestinal tract micro-flora and dietary phytase on inositol hexaphosphate hydrolysis in the chicken. Poultry Science 79 (Suppl. 1): 11 (Abstr.).

Ketels, E., and DeGroote, G. 1988. The relative bioavailability and ileal digestibility of phosphorus from mineral and animal sources. Pages 873-874 in: Proceedings XVIII World's Poultry Congress, Nagoya, Japan.

Kies, A.K., De Jonge, L.H., Kemme, P.A., and Jongbloed, A.W. 2006. Interaction between protein, phytate, and microbial phytase. In vitro studies. J ournal of Agricultural and Food Chemistry 54: 1753-1758.

Kilburn, J., and Edwards, H.M., Jr. 2001. The response of broilers to the feeding of mash and pelleted diets containing maize of varying particle sizes. British Poultry Science 42: 484-492.

Kilburn, J., and Edwards, H.M., Jr. 2004. The effect of particle size of commercial soybean meal on performance and nutrient utilization of broiler chicks. Poultry Science 83: 428-432.

Larbier, M., and Leclercq, B. 1994. Nutrition and Feeding of Poultry. Nottingham University Press. Nottingham, UK.

Larson, S.R., Young, K.A., Cook, A., Blake, T.K., and Raboy, V. 1998. Linkage mapping of two mutations that reduce phytic acid content of barley grain. Theoretical and Applied Genetics 97: 141146.

Leske, K., and Coon, C.N. 2002. The development of feedstuff retainable phosphorus values for broilers. Poultry Science 81:1681-1693.

Leytem, A.B., Willing, B.P., and Thacker, P.A. 2008. Phytate utilization and phosphorus excretion by broiler chickens fed diets containing cereal grains varying in phytate and phytase content. Animal Feed Science and Technology 146:160-168.

Li, Y.C., Ledoux, D.R., Veum, T.L., Raboy, V., and Ertl, D.S. 2000. Effects of low phytic acid corn on phosphorus utilization, performance, and bone mineralization in broiler chicks. Poultry Science 79: 1444-1450.

Li, Y.C., Ledoux, D.R., Veum, T.L., Raboy, V., and Zyla, K. 2001. Low phytic acid barley improves performance, bone mineralization, and phosphorus retention in turkey poults. J ournal of Applied Poultry Research 10: 178-185.

Liebert, F., Wecke, C, and Schoner, F.J. 1993. Phytase activities in different gut contents of chickens are dependent on level of phosphorus and phytase supplementation. Pages 202-205 in: Wenk, C., and Boessinger, M. (eds.), Proceedings of the First Symposium on Enzymes in Animal Nutrition. Karthause Ittingen, Switzerland.

Liem, A., Pesti, G.M., and Edwards, H.M., Jr. 2008. The effect of several organic acids on phytate phosphorus hydrolysis in broiler chicks. Poultry Science 87:689-693.

Liu, J.B., Chen, D.W., and Adeola, O. 2013. Phosphorus digestibility response of broiler chickens to dietary calcium-to-phosphorus ratios. Poultry science 92:1572-1578.

Lopez, H.W., Leenhardt, F., Coudray, C., and Remesy, C. 2002. Minerals and phytic acid interactions: is it a real problem for human nutrition?. International Journal of Food Science and Technology 37: 727-739.

López-Guisa, J.M., Harned, M.C., Dubielzig, R., Rao, S.C., and Marlett, J.A. 1988. Processed oat hulls as potential dietary fiber sources in rats. Journal of Nutrition 118:953-962.

Lucca, P., Hurrell, R., and Potrykus, I. 2001. Genetic engineering approaches to improve the bioavailability and the level of iron in rice grains. Theoretical and Applied Genetics 102:392-397.

Maenz, D.D., and Classen, H.L. 1998. Phytase activity in the small intestine brush border membrane of the chicken. Poultry Science 77:557-563. 
Maenz, D.D. 2001. Enzymatic and other characteristics of phytases as they relate to their use in animal feeds. Pages 61-84 in: Bedford, M.R., and Partridge, G.G. (eds.). Enzymes in farm animal nutrition. CABI Publishing, UK.

Manangi, M.K., and Coon, C.N. 2008. Phytate phosphorus hydrolysis in broilers in response to dietary phytase, calcium, and phosphorus concentrations. Poultry Science 87: 1577-1586.

Marounek, M., Skrivan, M., Rosero, O., and Rop, O. 2010. Intestinal and total tract phytate digestibility and phytase activity in the digestive tract of laying hens fed a wheat-maizesoybean diet. J ournal of Animal Feed Science 19:430-439.

Marounek, M., Skrivan, M., Dlouha, G., and Brenova, N. 2008. Availability of phytate phosphorus and endogenous phytase activity in the digestive tract of laying hens 20 and 47 weeks old. Animal of Feed Science Technology 146:353-359.

Mateos, G.G., Jiménez-Moreno, E., Serrano, M.P., and Lázaro, R.P. 2012. Poultry response to high levels of dietary fiber sources varying in physical and chemical characteristics. Journal of Applied Poultry Research 21:156-174.

Mathur, C.R., Reddy, C.V., and Siddiqui, S.M. 1982. Determination of calcium and phosphorus requirement for cage layers. Indian Journal of Animal Science 52:768-771.

McCuaig, L.W., Davies, M.I., and Motzok, I. 1972. Intestinal alkaline phosphatase and phytase of chicks: Effect of dietary magnesium, calcium, phosphorus and thyroactive casein. Poultry Science 51:526-530.

McDonald, P., Edwards, R.A., Greenhalgh, J.F.D., and Morgan, C.A. 2002. Minerals. Pages 108-145 in: Animal Nutrition, 6th Edition. Longman Singapore Publishers (Pte) Ltd. Singapore.

McGillivary, J.J . 1978. Biological availability of phosphorus sources. Pages 73-85 in: Proceedings 1st Annual International Minerals Conference, IMC Corporation, Mundelein, IL.

Meidinger, R.G., Ajakaiye, A., Fan, M.Z., Zhang, J., Phillips, J.P., and Forsberg, C.W. 2013. Digestive utilization of phosphorus from plant-based diets in the Cassie line of transgenic Yorkshire pigs that secrete phytase in the saliva. Journal of Animal Science 91:1307-1320.

Mitchell, H.H. 1947. The mineral requirements of farm animals. J ournal of Animal Science 6:365-377.

Mitchell, R.D., and Edwards, H.M., J r. 1996. Additive effects of 1,25-dihydroxycholecalciferol and phytase on phytate phosphorus utilization and related parameters in broiler chickens. Poultry Science 75:111-119.

Mohammed, A., Gibney, M.J., and Taylor, T.G. 1991. The effect of dietary levels of inorganic phosphorus, calcium and cholecalciferol on the digestibility of phytate phosphorus by the chick. British Journal of Nutrition 66: 251-259.

Montagne, L., Toullec, R., and Lallès, J.P. 2001. Intestinal digestion of dietary and endogenous proteins along the small intestine of calves fed soybean or potato. J ournal of Animal Science 79: 2719-2730.

Myers, W.D., Ludden, P.A., Nayigihugu, V., and Hess, B.W. 2004. Technical Note: A procedure for the preparation and quantitative analysis of samples for titanium dioxide. Journal of Animal Science 82: 179-183.

NRC (National Research Council), 1994: Nutrient Requirements of Poultry, 9th rev. ed. National Academy Press, Washington, DC, USA.

Nasi, J.M., Helander, E.M., and Partanen, K.H. 1995. Availability for growing pigs of minerals and protein of a high phytate barley-rapeseed meal diet treated with Aspergillus niger phytase or soaked with whey. Animal Feed Science Technology 56:83-98.

Nelson, T.S. 1976. The hydrolysis of phytate phosphorus by chicks and laying hens. Poultry Science 55: 2262-2264.

Nelson, T.S., Harris, G.C., Kirby, L.K., and Johnson, Z.B. 1990. Effect of calcium and phosphorus on the incidence of leg abnormalities in growing broilers. Poultry Science 69: 1496-1502.

Neset, T.S., and Cordell, D. 2011. Global phosphorus scarcity: identifying synergies for a sustainable future. Journal of the Science of Food and Agriculture 92:2-6.

Newcombe, M., and Summers, J.D. 1985. Effect of increasing cellulose in diets fed as crumbles or mash on the food intake and weight gains of broiler and leghorn chicks. British Poultry Science 26: $35-42$.

Newkirk, R.W., and Classen, H.L. 1998. In vitro hydrolysis of phytate in canola meal with purified and crude sources of phytase. Animal Feed Science Technology 72:315-327.

Nwokolo, E.N., and Bragg, D.B. 1977. Influence of phytic acid and crude fibre on the availability of minerals from four protein supplements in growing chicks. Canadian Journal of Animal Science 57: 475-477.

Nys, Y., Frapin, D., and Pointillart, P. 1996. Occurrence of phytase in plants, animals and microorganism. Pages 213-240 in: Coelho, M.B. and Kornegay, E.T. (eds.) Phytase in Animal Nutrition and Waste Management. BASF Corporation, Mount Olive, New Jersey.

Onyango, E.M., Bedford, M.R., and Adeola, O. 2005. Phytase activity along the digestive tract of the broiler chick: A comparative study of an Escherichia coli-derived and Peniophora lycii phytase. Canadian Journal of Animal Science 85:61-68.

Orban, J.I., and Roland, D.A. 1992. The effect of varying bone meal sources on phosphorus utilization by 3 week old broilers. Journal of Applied Poultry Research 1:75-83.

Peeler, H.T. 1972. Biological availability of nutrients in feeds: Availability of major mineral ions. Journal of Animal Science 35:695-712

Peeler, H.T. 1982. Phosphorus. A review. Pages 1-23 in: Proceedings 5th Ann. Intl. Minerals Conf., Mundelein, IL. 
Plumstead, P.W., Leytem, A.B., Maguire, R.O., Spear, J.W., Kwanyuen, P., and Brake, J. 2008. Interaction of Calcium and Phytate in Broiler Diets. 1. Effects on apparent prececal digestibility and retention of phosphorus. Poultry Science 87:449-458.

Pointillart, A., Fourdin, A., and Fontaine, N. 1987. I mportance of cereal phytase activity for phytate phosphorus utilization by growing pigs fed diets containing triticale or corn. J ournal of Nutrition 117: 907-913.

Potter, L.M., Potchanakorn, M., Ravindran, V., and Kornegay, E.T. 1995. Bioavailability of phosphorus in various phosphate sources using body weight and toe ash as response criteria. Poultry Science 74:813-820.

Powell, S., Bidner, T.D., and Southern, L. L. 2011. Phytase supplementation improved growth performance and bone characteristics in broilers fed varying levels of dietary calcium. Poultry Science 90: 604-608.

Punna, S., and Roland, D.A. 1999. Variation in phytate phosphorus utilization within the same broiler strain. Journal of Applied Poultry Research 8:10-15.

Qian, H., Kornegay, E.T., and Veit, H.P. 1996a. Effects of supplemental phytase and phosphorus on histological, mechanical and chemical traits of tibia and performance of turkeys fed on a soyabeanmeal-based semi-purified diets high in phytate phosphorus. British Journal of Nutrition 76:263272.

Qian, H., Veit, H.P., Kornegay, E.T., and Denbow, D.M. 1996b. Effects of supplemental phytase and phosphorus on histological and other tibial bone characteristics and performances of broilers fed semi-purified diet. Poultry Science 75:618-626.

Qian, H., Kornegay, E.T., and Denbow, D.M. 1997. Utilization of phytate P and calcium as influenced by microbial phytase, cholecalciferol, and the calcium: total $\mathrm{P}$ ratio in broiler diets. Poultry Science 76:37-46.

Raboy, V. 2001. Seeds for a better future: 'low phytate' grains help to overcome malnutrition and reduce pollution. Trends in Plant Science 6: 458-462.

Raghavendra, P., and P. M. Halami. 2009. Screening, selection and characterization of phytic acid degrading lactic acid bacteria from chicken intestine. Int. J. Food Microbiol. 133(1-2): 129-134.

Rama Rao, S.V., Raju, M.V.L.N., Reddy, M.R., Pavani, P., Shyam Sunder, G., and Sharma, R.P. 2003. Dietary calcium and non-phytin phosphorus interaction on growth, bone mineralization and mineral retention in broiler starter chicks. Asian-Australasian J ournal of Animal Sciences 16: 719-725.

Rama Rao, S.V., Ravindra Reddy, V., and Ramasubba Reddy, V. 1999. Enhancement of phytate phosphorus availability in the diets of commercial broilers and layers. Animal Feed Science and Technology 79:211-222.

Ravindran, V., Ravindran, G., and Sivalogan, S. 1994. Total and phytate phosphorus contents of various foods and feedstuffs of plant origin. Food Chemistry 50: 133-136.

Ravindran, V., Bryden, W.L., and Kornegay, E.T. 1995. Phytases: Occurrence, bioavailability, and implications in poultry nutrition. Poultry and Avian Biology Reviews 6:125-143.

Ravindran, V., Cabahug, S., Ravindran, G., Selle, P.H., and Bryden, W.L. 2000. Response of broiler chickens to microbial phytase supplementation as influenced by dietary phytic acid and nonphytate phosphorous levels. II. Effects on apparent metabolisable energy, nutrient digestibility and nutrient retention. British Poultry Science 41: 193-200.

Ravindran, V., Wu, Y.B., and Hendriks, W.H. 2004. Effects of sex and dietary phosphorus level on the apparent metabolozable energy and nutrient digestibility in broiler chickens. Archives of Animal Nutrition 58:5 405-411.

Ravindran, V., Morel, P.C., Partridge, G.G., Hruby, M., and Sands, J.S. 2006. Influence of an Escherichia coli-derived phytase on nutrient utilization in broiler starters fed diets containing varying concentrations of phytic acid. Poultry Science 85:82-89.

Ravindran, V. 2012. Poultry feed availability and nutrition in developing countries. Available online at http://www. fao.or, accessed on 13 May 2014.

Richards, I.R., and Dawson, D.J. 2008. Phosphorus imports, exports, fluxes and sinks in Europe. Pages 1-28 in: Proceedings 638, International Fertilizer Society, York, UK.

Rodehutscord, M., and Dieckmann, A. 2005. Comparative studies with three-week-old chickens, turkeys, ducks, and quails on the response in phosphorus utilization to a supplementation of monobasic calcium phosphate. Poultry Science 84:1252-1260.

Rodehutscord, M. 2013. Determination of phosphorus availability in poultry. World's Poultry Science Journal 69:687-698.

Rogel, A.M., Balnave, D., Bryden, W.L., and Annison, E.F. 1987a. Improvement of raw potato starch digestion in chickens by feeding oat hulls and other fibrous feedstuffs. Crop and Pasture Science 38: 629-637.

Rogel, A.M., Annison, E.F., Bryden, W.L., and Balnave, D. 1987b. The digestion of wheat starch in broiler chickens. Crop and Pasture Science 38:639-649.

Rousseau, X., Létourneau-Montminy, M.P., Même, N., Magnin, M., Nys, Y., and A. Narcy, A. 2012. Phosphorus utilization in finishing broiler chickens: Effects of dietary calcium and microbial phytase. Poultry Science 91:2829-2837.

Sandberg, A.N., Larsen, T., and Sandstrom, B. 1993. High dietary calcium level decreases colonic phytate degradation in pigs fed a rapeseed diet. Journal of Nutrition 123:559-566.

Sarker, P.K., Fukada, H., and Masumoto, T. 2009. Phosphorus availability from inorganic phosphorus sources in yellowtail (Seriola quinqueradiata Termminck and Schlegel) Aquaculture 289: 113-117.

Scheideler, S.E., and Sell, J.L. 1987. Utilization of phytate phosphorus in laying hens as influenced by dietary phosphorus and calcium. Nutritional Report International 35: 1073. 
Schlemmer, U., Jany, K.D., Berk, A., Schulz, E., and Rechkemmer, G. 2001. Degradation of phytate in the gut of pigs - pathway of gastrointestinal inositol phosphate hydrolysis and enzymes involved. Archives of Animal Nutrition 55:255-280.

Schoner, F.J., Hoppe, P.P., Schwarz, G., and Wiesche, H. 1993. Comparison of microbial phytase and inorganic-phosphate in male chickens - the influence on performance data, mineral retention and dietary calcium. Journal of Animal Physiology and Animal Nutrition 69:235-244.

Scott, M.L., Neshim, M.C., and Young, R.J. 1982. Nutrition of the Chicken. M.L. Scott and Associates Ithaca NY.

Sebastian, S., Touchburn, S.P., and Chavez, E.R. 1998. I mplication of phytic acid and supplemental microbial phytase in poultry nutrition: a review. World's Poultry Science J ournal 54:27-47.

Sell, J.L., Scheideler, S.E., and Rahn, B.E. 1987. Influence of different phosphorus phase feeding programmes and dietary calcium level on performance and body phosphorus of laying hens. Poultry Science 6: 1524-1530.

Selle, P.H., Walker, A.R., and Bryden, W.L. 2003. Total and phytate-phosphorus contents and phytase activity of Australian-sourced feed ingredients for pigs and poultry. Australian Journal of Experimental Agriculture 43:475-475.

Selle, P.H., and Ravindran, V. 2007. Microbial phytase in poultry nutrition. Animal Feed Science and Technology 135:1- 41.

Selle, P.H., Cowieson, A.J., and Ravindran, V. 2009. Consequences of calcium interactions with phytate and phytase for poultry and pigs. Livestock Science 124:126-141.

Selle, P.H., Cowieson, A.J., Cowieson, N.P., and Ravindran, V. 2012. Protein-phytate interactions in pig and poultry nutrition: a reappraisal. Nutrition Research Reviews 25:1-17.

Shafey, T.M., and McDonald, M.W. 1991. The effects of dietary calcium, phosphorus, and protein on the performance and nutrient utilization of broiler chickens. Poultry Science 70:548-553.

Shastak, Y., Witzig, M., Hartung, K., and Rodehutscord, M. 2012. Comparison and evaluation of bone measurements for the assessment of mineral phosphorus sources in broilers. Poultry Science 91:2210-2220.

Short, F.J., Gorton, P., Wiseman, J., and Boorman, K.N. 1996. Determination of titanium dioxide added as an inert marker in chicken digestibility studies. Animal Feed Science and Technology 59:215-221.

Simons, P.C.M., Versteegh, H.A.J., Jongbloed, A., Kemme, P.A., Slump, P., Bos, K.D., and Verschoor, G.J. 1990. Improvement of phosphorus availability by microbial phytase in broilers and pigs. British Journal of Nutrition 64:525-540.

Singh, P.K. 2008. Significance of phytic acid and supplemental phytase in chicken nutrition: A review. World's Poultry Science Journal 64:553-580.

Sklan, D., Smirnov, A., and Plavnik, I. 2003. The effect of dietary fibre on the small intestines and apparent digestion in the turkey. British Poultry Science 44:735-740.

Soares, J.H. 1995. Phosphorus bioavailability. Pages 257-294 in: Ammerman, C.B., Baker, D.H., and Lewis, A.J. (eds.). Bioavailability of nutrients for animals. Academic Press, New York.

Sooncharernying, S., and Edwards, H.M. 1993. Phytate content of excreta and phytate retention in the gastrointestinal tract of young chickens. Poultry Science 72:1906-1916.

Speedy, A.W. 2003. Global production and consumption of animal source foods. In Supplement: Animal source foods to improve micronutrient nutrition in developing countries. Journal of Nutrition 133: 4048-4053.

Steiner, T., Mosenthin, R., Zimmermann, B., Greiner, R., and Roth, S. 2007. Distribution of phytase activity, total phosphorus and phytate phosphorus in legume seed, cereals and cereal by-products as influenced by harvest year and cultivar. Animal Feed Science and Technology 133:320-334.

Subba, Rao. K., and Narasinga, Rao, B.S. 1983. Studies on iron chelation by phytate by phytate and the influence of other mineral ions on it. Nutritional Reports International 28:771-782.

Tamim, N.M., and Angel, R. 2003. Phytate phosphorus hydrolysis as influenced by dietary calcium and micro-mineral source in broiler diets. Journal of Agricultural and Food Chemistry 51:4687-4693.

Tamim, N.M., Angel, R, and Christman, M. 2004. Influence of dietary calcium and phytase on phytate phosphorus hydrolysis in broiler chickens. Poultry Science 83:1358-1367.

Taylor, T.G., and Coleman, J.W. 1979. A comparative study of the absorption of calcium and the availability of phytase phosphorus in the golden hamster and the laboratory rat. British Journal of Nutrition 42:113-119.

Ton Nu, M.A., Blaabjerg, K., and Poulsen, H.B. 2014. Effect of particle size and microbial phytase on phytate degradation in incubated maize and soybean meal. Animal 8:534-541.

Toor, G.S., and Haggard, B.E. 2009. Phosphorus and trace metal dynamics in soil ammended with poultry litter and granulates. Soil Use Manual 25:409-18.

Turner, B.L., Richardson, A.E., and Mullaney, E.J. (eds.). 2006. Inositol phosphates: linking agriculture and the environment. CABI.

Underwood, E.J., and Suttle, N.F. 1999. The mineral nutrition of livestock. 3rd ed. New York: CABI Publishing, 598p.

Van der Klis, J. D., and M. C. Blok. 1997. Definitief systeem opneembaar fosfor pluimvee. CVB Documentatierapport nr. 20. Centraal Veevoederbureau, Lelystad, September 1997.

Van der Klis, J.D., and Versteegh, H.A.J. 1996. Het gebruik van het opneembaar fosforsysteem bij leghennen. DLO, Institute for Animal Sciences and Health, Lelystad.

Van der Klis, J.D. and Versteegh, H.A.J . 1999. Phosphorus nutrition of poultry. Pages 309-320 in: Garnsworthy, P.C. and Wiseman, J. (eds.) Recent Developments in Poultry Nutrition 2. Nottingham University Press., Nottingham. 
Van Krimpen, M.M., Kwakkel, R.P., Van Der Peet-Schwering, C.M.C., Den Hartog, L.A., and Verstegen, M.W.A. 2011. Effects of dietary energy concentration, nonstarch polysaccharide concentration, and particle sizes of nonstarch polysaccharides on digesta mean retention time and gut development in laying hens. British Poultry Science 52:730-741.

Van Krimpen, M.M., Van Diepen, J.Th.M., Van Wikselaar, P.G., Bikker, P., and Jongbloed, A.W. 2013. Effects of available phosphorus (aP), calcium/aP ratio, and growth rate on $\mathrm{P}$ deposition, $\mathrm{P}$ digestibility, performance and leg quality in broilers. Report 670.

Van Krimpen, M. M., R. A. Dekker, R. A. Van Emous, P. Bikker, E. M. A. M. Bruininx, and A. G. Van der Lee. 2016. Response of broilers on incremental dietary $p$ content and consequences for $p$ requirements. Livestock Research Report 931, Wageningen.

Viljoen, J. 2001. Utilisation of feed phosphates: Fact or confusion? Afma matrix. December: pp. 24-27.

Waldroup, P.W. 1999. Nutritional approaches to reducing phosphorus excretion by poultry. Poultry Science 78: 683-691.

Waldenstedt, L. 2006. Nutritional factors of importance for optimal leg health in broilers: A review. Animal Feed Science and Technology 126:291-307.

WPSA, R., M. 2013. Determination of phosphorus availability in poultry. Worlds Poult. Sci. J. 69(3): 687-698.

Wodzinski, R.J., and Ullah, A.H.J. 1996. Phytase. Advance Applied Microbiology 42:263-302.

Wu, P., Tian, J.C., Walker, C.E., and Wang F.C. Determination of phytic acid in cereals-a brief review. International Journal of Food Science and Technology 44:1671-1676.

Yan, F., Kersey, J.H., and Waldroup, P.W. 2001. Phosphorus requirements of broiler chicks three to six weeks of age as influenced by phytase supplementation. Poultry Science 80:455-459.

Yan, F., Angel, R., Ashwell, C., Mitchell, A., and Christman, M. 2005. Evaluation of the broiler's ability to adapt to an early moderate deficiency of phosphorus and calcium. Poultry Science 84:12321241.

Zeller, E., M. Schollenberger, I. Kuhn, and M. Rodehutscord. 2015a. Hydrolysis of phytate and formation of inositol phosphate isomers without or with supplemented phytases in different segments of the digestive tract of broilers. J. Nutr. Sci. 4: 12 .

Zeller, E., M. Schollenberger, M. Witzig, Y. Shastak, I. Kuhn, L. E. Hoelzle, and M. Rodehutscord. 2015b. Interactions between supplemented mineral phosphorus and phytase on phytate hydrolysis and inositol phosphates in the small intestine of broilers. Poult. Sci. 94(5): 1018-1029.

Zhang, W., Aggrey, S.E., Pesti, G.M., Edwards, H.M., Jr., and Bakalli, R.I. 2003. Genetics of phytate phosphorus bioavailability: Heritability and genetic correlations with growth and feed utilization traits in a random bred chicken population. Poultry Science 82:1075-1079.

Ziaei, N., Guy, J.H., Edwards, S.A., Blanchard, P.J., Ward, J., and Feuerstein, D. 2007. Effect of gender on factors affecting excreta dry matter content of broiler chickens. J ournal of Applied Poultry Research 16:226-233. 


\section{Appendix 1 Diagram of the experimental facility}

\begin{tabular}{|c|c|c|c|c|c|c|c|c|c|c|c|c|}
\hline \multirow[t]{11}{*}{ Door } & \multicolumn{12}{|c|}{ Left Corridor } \\
\hline & P48 & P47 & P46 & P45 & P44 & P43 & P42 & P41 & P40 & P39 & P38 & P37 \\
\hline & T5 & $\mathrm{T} 2$ & T12 & $\mathrm{T} 7$ & T10 & T9 & T6 & T4 & T1 & T8 & T3 & T11 \\
\hline & P25 & P26 & P27 & P28 & P29 & P30 & P31 & P32 & P33 & P34 & P35 & P36 \\
\hline & $\mathrm{T} 2$ & T3 & T5 & T1 & T8 & T11 & T12 & T6 & $\mathrm{T7}$ & T4 & T9 & $\mathrm{T} 10$ \\
\hline & \multicolumn{12}{|c|}{ Center Corridor } \\
\hline & P24 & P23 & P22 & P21 & P20 & P19 & P18 & P17 & P16 & P15 & P14 & P13 \\
\hline & T12 & T10 & T11 & T9 & T7 & T4 & T3 & T5 & T6 & $\mathrm{T} 2$ & T8 & T1 \\
\hline & P1 & P2 & P3 & P4 & P5 & P6 & P7 & P8 & P9 & P10 & P11 & P12 \\
\hline & T9 & T8 & T11 & $\mathrm{T} 2$ & T4 & T1 & T10 & T3 & T12 & $\mathrm{T} 7$ & T5 & T6 \\
\hline & \multicolumn{12}{|c|}{ Right Corridor } \\
\hline
\end{tabular}

\section{Large room}

\begin{tabular}{|c|c|c|c|c|c|c|c|c|c|c|c|c|}
\hline \multirow[t]{6}{*}{ Door } & \multicolumn{12}{|c|}{ Left Corridor } \\
\hline & P61 & P62 & P63 & P64 & P65 & P66 & P67 & P68 & P69 & P70 & P71 & P72 \\
\hline & T7 & $\mathrm{T} 2$ & T5 & T4 & T11 & T9 & $\mathrm{T} 1$ & T10 & T6 & T8 & T12 & T3 \\
\hline & P49 & P50 & P51 & P52 & P53 & P54 & P55 & P56 & P57 & P58 & P59 & P60 \\
\hline & T8 & T9 & $\mathrm{T} 1$ & T12 & T10 & $\mathrm{T} 2$ & T6 & T3 & T11 & $\mathrm{T7}$ & T5 & T4 \\
\hline & Right $C$ & idor & & & & & & & & & & \\
\hline
\end{tabular}

\section{Small room}

$\mathrm{P}=$ pen number

$\mathrm{T}=$ treatment 


\section{Appendix 2 Photos of the experimental facility}

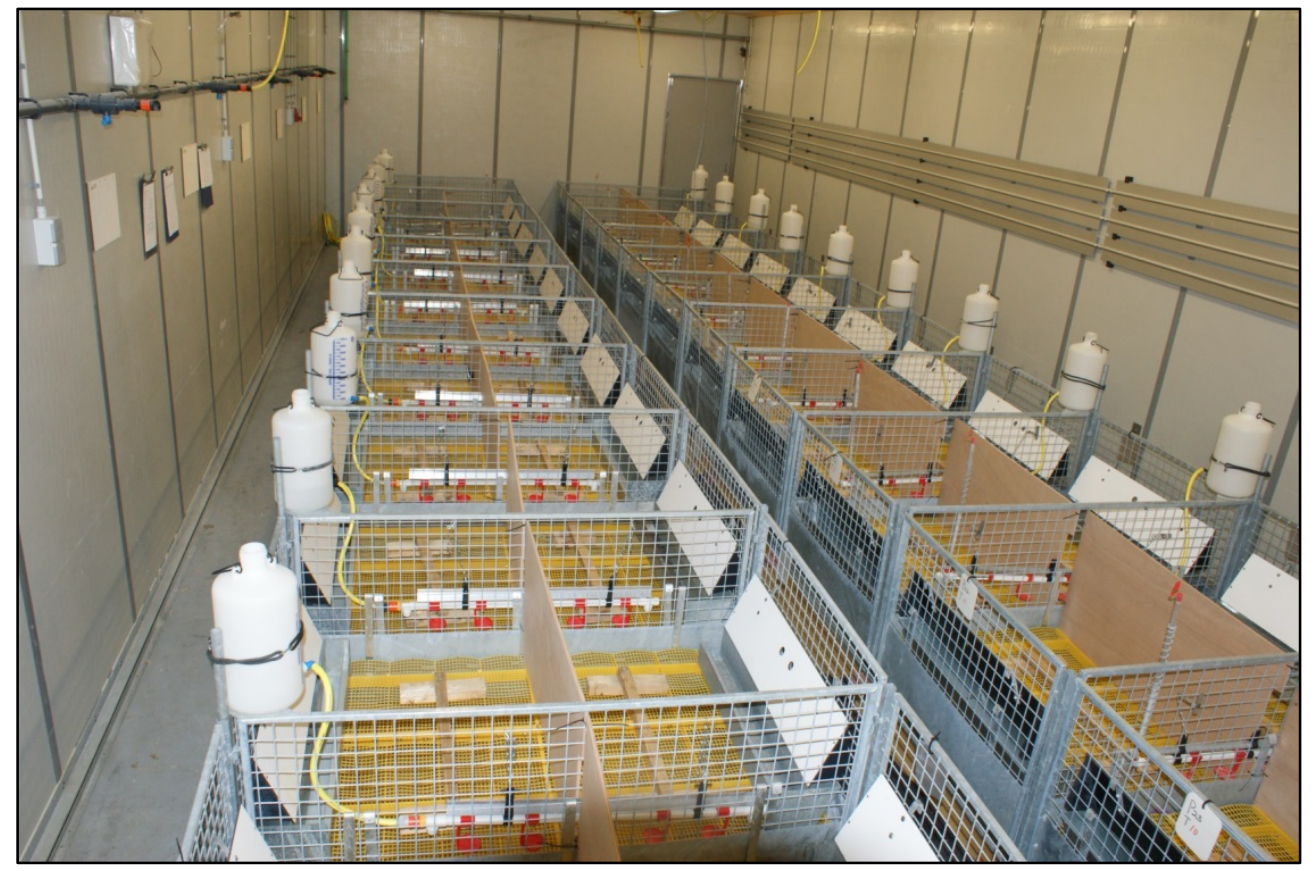

Overview of the experimental facility.

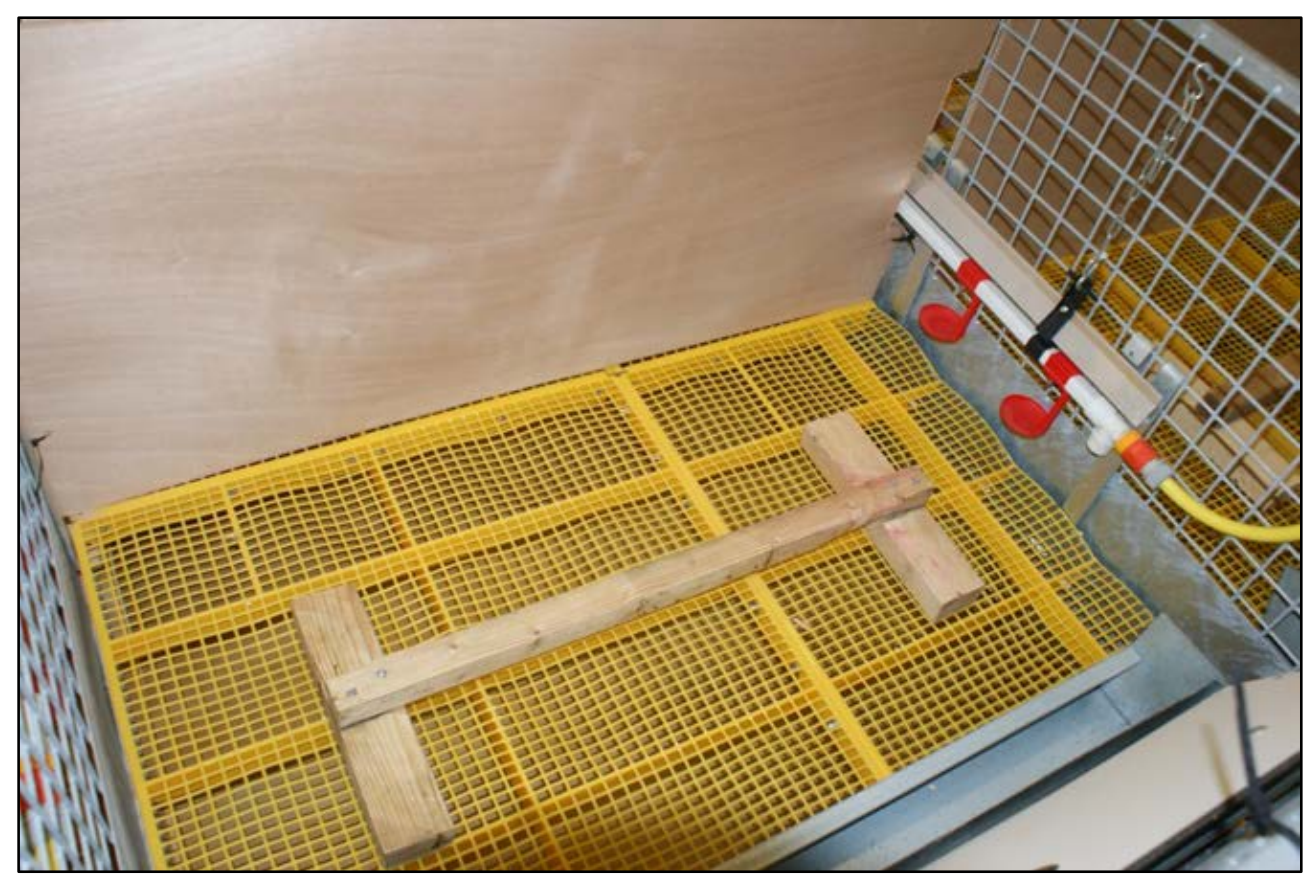

Overview of an experimental unit. 

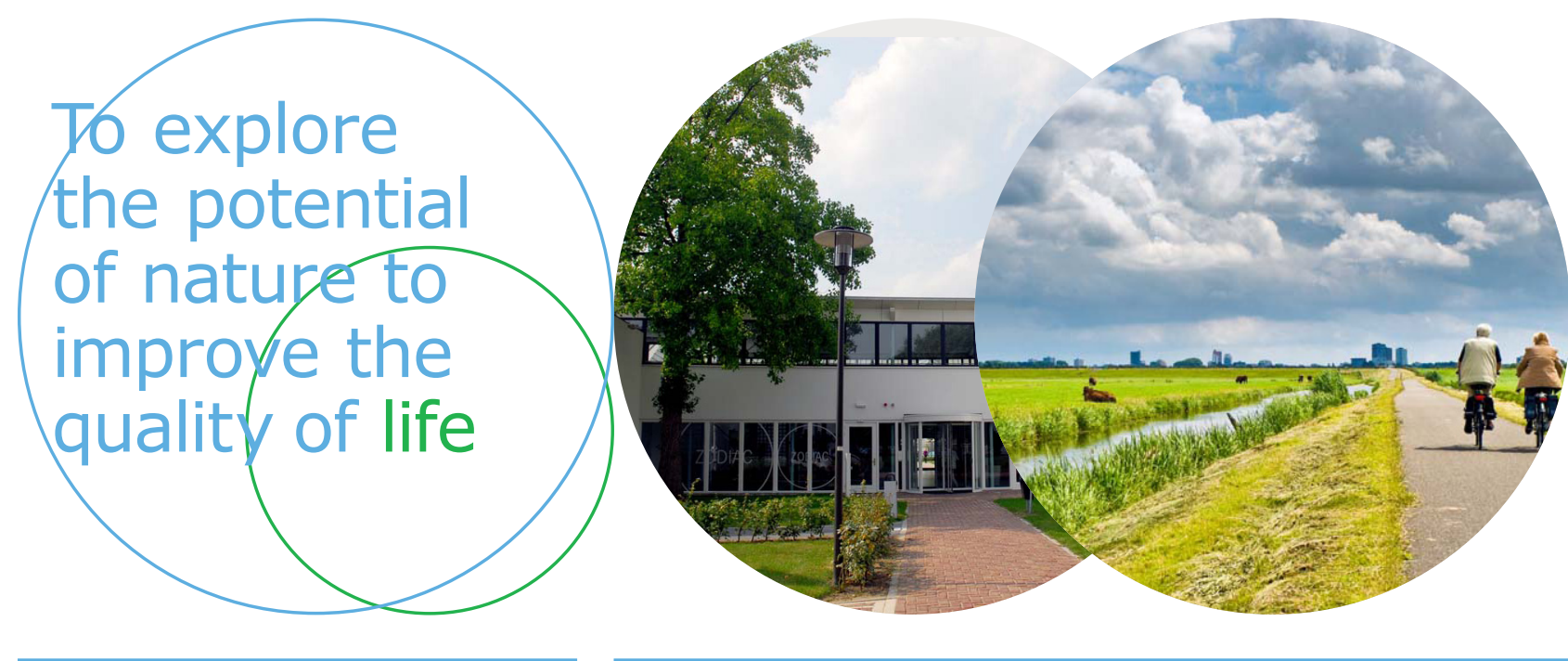

Wageningen Livestock Research P.O. Box 338

$6700 \mathrm{AH}$ Wageningen

The Netherlands

$\mathrm{T}+31(0) 317483953$

E info.livestockresearch@wur.nl www.wur.nl/livestock-research
Together with our clients, we integrate scientific know-how and practical experience to develop livestock concepts for the 21st century. With our expertise on innovative livestock systems, nutrition, welfare, genetics and environmental impact of livestock farming and our state-of-the art research facilities, such as Dairy Campus and Swine Innovation Centre Sterksel, we support our customers to find solutions for current and future challenges.

The mission of Wageningen University \& Research is 'To explore the potential of nature to improve the quality of life'. Within Wageningen University, nine specialised research institutes of the DLO Foundation have joined forces with Wageningen University to help answer the most important questions in the domain of healthy food and living environment. With approximately 30 locations, 6,000 members of staff and 10,000 students, Wageningen University is one of the leading organisations in its domain worldwide. The integral approach to problems and the cooperation between the various disciplines are at the heart of the unique Wageningen Approach. 